\title{
32. JURASSIC THROUGH EARLY CRETACEOUS SEDIMENTATION HISTORY OF THE CENTRAL EQUATORIAL PACIFIC AND OF SITES 800 AND $801^{1}$
}

\author{
James G. Ogg, ${ }^{2}$ Susan M. Karl, ${ }^{3}$ and Richard J. Behl ${ }^{4}$
}

\begin{abstract}
Sedimentation in the central Pacific during the Jurassic and Early Cretaceous was dominated by abundant biogenic silica. A synthesis of the stratigraphy, lithology, petrology, and geochemistry of the radiolarites in Sites 801 and 800 documents the sedimentation processes and trends in the equatorial central Pacific from the Middle Jurassic through the Early Cretaceous. Paleolatitude and paleodepth reconstructions enable comparisons with previous DSDP sites and identification of the general patterns of sedimentation over a wide region of the Pacific.

Clayey radiolarites dominated sedimentation on Pacific oceanic crust within tropical paleolatitudes from at least the latest Bathonian through Tithonian. Radiolarian productivity rose to a peak within $5^{\circ}$ of the paleoequator, where accumulation rates of biogenic silica exceeded $1000 \mathrm{~g} / \mathrm{cm}^{2} / \mathrm{m}$.y. Wavy-bedded radiolarian cherts developed in the upper Tithonian at Site 801 coinciding with the proximity of this site to the paleoequator. Ribbon-bedding of some radiolarian cherts exposed on Pacific margins may have formed from silicification of radiolarite deposited near the equatorial high-productivity zone where radiolarian/clay ratios were high. Silicification processes in sediments extensively mixed by bioturbation or enriched in clay or carbonate generally resulted in discontinuous bands or nodules of porcellanite or chert, e.g., a "knobby" radiolarite. Ribbon-bedded cherts require primary alternations of radiolarian-rich and clay-rich layers as an initial structural template, coupled with abundant biogenic silica in both layers. During diagenesis, migration of silica from clay-rich layers leaves radiolarian "ghosts" or voids, and the precipitation in adjacent radiolarite layers results in silicification of the inter-radiolarian matrix and infilling of radiolarian tests. Alternations of claystone and clay-rich radiolarian grainstone were deposited during the Callovian at Site 801 and during the Berriasian-Valanginian at Site 800 , but did not silicify to form bedded chert.

Carbonate was not preserved on the Pacific oceanic floor or spreading ridges during the Jurassic, perhaps due to an elevated level of dissolved carbon dioxide. During the Berriasian through Hauterivian, the carbonate compensation depth (CCD) descended to approximately $3500 \mathrm{~m}$, permitting the accumulation of siliceous limestones at near-ridge sites. Carbonate accumulation rates exceeded $1500 \mathrm{~g} / \mathrm{cm}^{2} / \mathrm{m}$.y. at sites above the CCD, yet there is no evidence of an equatorial carbonate bulge during the Early Cretaceous. In the Barremian and Aptian, the CCD rose, coincident with the onset of mid-plate volcanic activity.

Abundance of $\mathrm{Fe}$ and $\mathrm{Mn}$ and the associated formation of authigenic Fe-smectite clays was a function of proximity to the spreading ridges, with secondary enrichments occurring during episodes of spreading-center reorganizations. Callovian radiolarite at Site 801 is anomalously depleted in $\mathrm{Mn}$, which resulted either from inhibited precipitation of Mn-oxides by lower $\mathrm{pH}$ of interstitial waters induced by high dissolved oceanic $\mathrm{CO}_{2}$ levels or from diagenetic mobilization of $\mathrm{Mn}$. Influx of terrigenous (eolian) clay apparently changed with paleolatitude and geological age.

Cyclic variations in productivity of radiolarians and of nannofossils and in the influx of terrigenous clay are attributed to Milankovitch climatic cycles of precession $(20,000 \mathrm{yr})$ and eccentricity $(100,000 \mathrm{yr})$. Diagenetic redistribution of biogenic silica and carbonate enhanced the expression of this cyclic sedimentation.

Jurassic and Lower Cretaceous sediments were deposited under oxygenated bottom-water conditions at all depths, accompanied by bioturbation and pervasive oxidation of organic carbon and metals. Despite the more "equable" climate conditions of the Mesozoic, the super-ocean of the Pacific experienced adequate deep-water circulation to prevent stagnation. Efficient nutrient recycling may have been a factor in the abundance of radiolarians in this ocean basin.
\end{abstract}

\section{INTRODUCTION}

During the Jurassic and Early Cretaceous, the Atlantic-Tethys seaway was a narrow channel crossing the Pangea super-continent, and the Pacific "Panthalasa" basin encompassed over half of the globe. Most of the deep-sea sedimentary record of this mega-Pacific has been lost through subduction, leaving only a few glimpses of Mesozoic oceanic sediments plastered around the circum-Pacific Rim within uplifted accretionary wedges or accreted terranes.

During the Middle Jurassic, the configuration of Pacific spreading ridges underwent a reorganization, perhaps associated with the simultaneous initiation of spreading in the Atlantic. The Pacific Plate apparently began at disrupted triple-junction of ridges as a triangular

\footnotetext{
'Larson, R. L., Lancelot, Y., et al., 1992. Proc. ODP, Sci. Results, 129: College Station. TX (Ocean Drilling Program).

${ }^{2}$ Department of Earth and Atmospheric Science, Purdue University, West Lafayette, IN 47907, U.S.A

${ }^{3}$ Branch of Alaskan Geology, U.S. Geological Survey, 4200 University Drive, Anchorage, AK 99508-4667, U.S.A.

${ }^{4}$ Earth Sciences Department, University of California, Santa Cruz, CA 95064, U.S.A.
}

plate bounded by three spreading centers (Hilde et al., 1976; Handschumacher et al., 1988). The Middle to Late Jurassic central portion of this expanding plate, which presently dominates the Pacific basin, is preserved in the western central Pacific (Fig. 1). An enormous outpouring of submarine basalts and associated building of volcanic seamounts during the middle Cretaceous has obscured and buried much of this Pacific crust. Not until the Ocean Drilling Program (ODP) Leg 129 drilling was the Jurassic sedimentary record of this remaining fragment of the mega-Pacific recovered.

Middle Jurassic through Lower Cretaceous sediments of Site 801 consist of radiolarites with varying proportions of clay and metalenrichment (Fig. 2) (Shipboard Scientific Party, 1990c). ${ }^{5}$ Lower Cretaceous sediments of Site 800 are also hematite-rich radiolarites

\footnotetext{
${ }^{5}$ In this paper, we use the term "radiolarite" in the general sense; any siliceous sediment that has more than $25 \%$ radiolarians or radiolarian casts is a "radiolarite," and the degree of silicification or type of bedding are not part of this definition. This is in contrast to the shipboard usage reported in Leg 129 Initial Reports, and the lithologic and diagenetic distinctions made by the physical properties and silica diagenesis studies of this volume (Fisher et al., this volume, and Behl and Smith, this volume).
} 


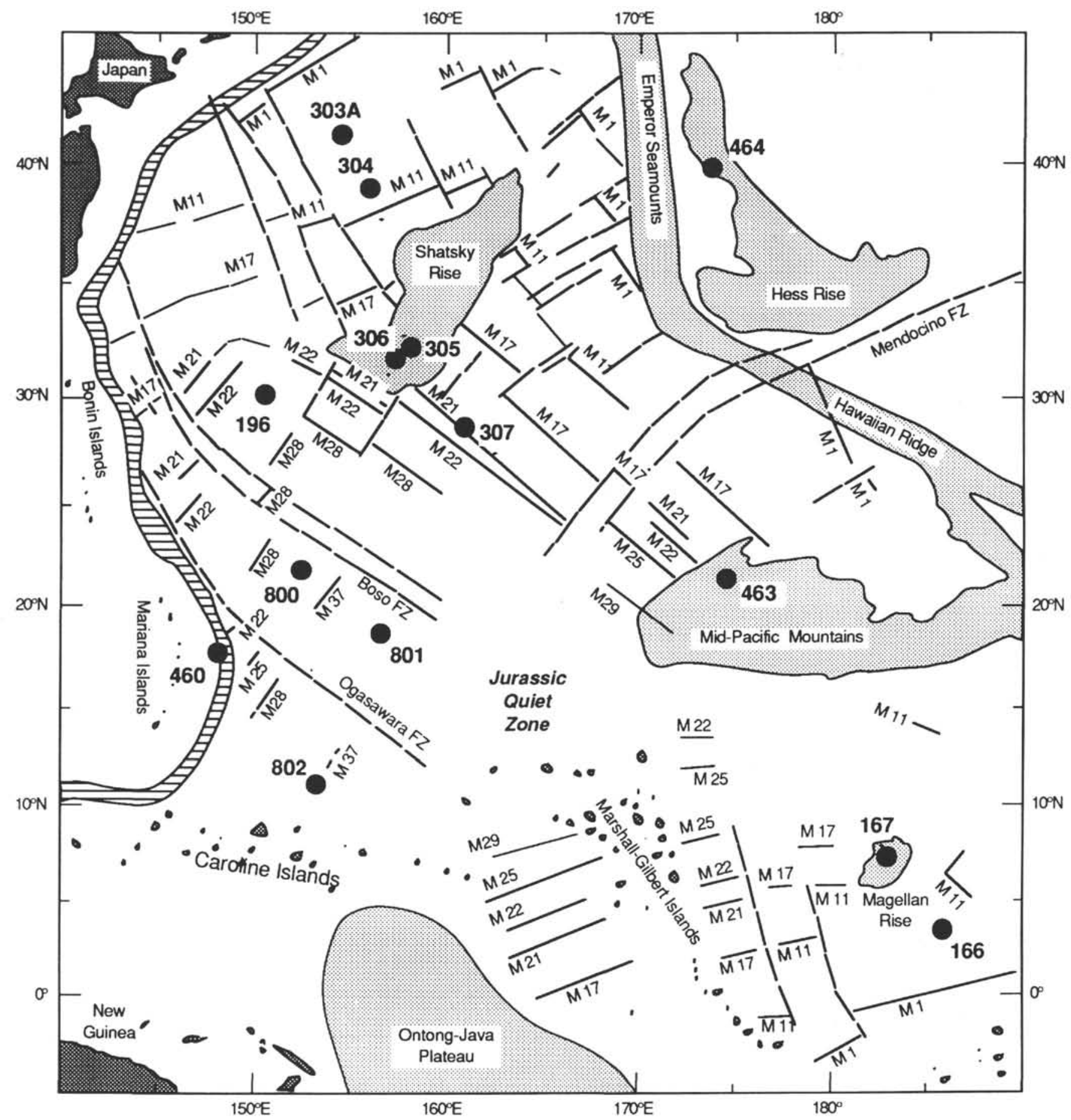

Figure 1. Location of ODP and DSDP sites drilled into Jurassic and Lower Cretaceous sediments. Oceanic plateaus and rises are lightly shaded, and emergent islands are darkly shaded. Hawaiian magnetic lineations are between Shatsky Rise and the Mid-Pacific Mountains, Japanese lineations are being subducted into the Mariana-Japan Trench (marked by a horizontal pattern), and the Phoenix lineations are near the equator. Magnetic anomaly M28 is the position of the ridges during the Oxfordian, M17 encloses the Jurassic portion of the Pacific Plate, M11 is the middle Valanginian configuration, and M1 marks the late Barremian extent of the plate. Modified from Larson and Sager (this volume).

with variable clay content; penetration of Jurassic strata was blocked by a diabase sill of presumed mid-Cretaceous age (Shipboard Scientific Party, 1990b). These sites reveal that this region of the tropical mega-Pacific was characterized by high radiolarian productivity and by oxygenated bottom waters, and that the paleoceanographic conditions were apparently sensitive to Milankovitch climatic cycles. The sites drifted northward during the Late Jurassic, reaching an equato- rial position in the Tithonian, then drifted southward, reaching about $15^{\circ}-17^{\circ} \mathrm{S}$ paleolatitude in the early Aptian. From early Aptian to present, the Pacific Plate has had a northward component of drift.

The sedimentary record from Sites 801 and 800 complements other Pacific DSDP sites that recovered Lower Cretaceous strata (Fig. 1). When combined with the scattered remnants of Jurassic oceanic sediments accreted onto Costa Rica, California, Alaska, and 
Japan, a general picture of the paleoceanography and sedimentary environments of the mega-Pacific begins to emerge. The sedimentary history of the mega-Pacific has a few similarities, but many contrasts, to the well-studied pelagic sedimentation of the coeval Atlantic and Tethys seaways. Some important common assumptions about ancient Pacific paleoceanography are in apparent conflict with this picture. For example, the common view that "most researchers believe that the pre-Miocene ocean had been one of generally warm water, little depth stratification, and slow circulation" (Theyer et al., 1989) is difficult to reconcile with high siliceous-organism productivity, widespread bottom water oxygenation, and sedimentary structures observed in cores.

In this paper, we present a comprehensive survey of the stratigraphy, sedimentary features, petrology, and geochemistry of the Middle Jurassic through Lower Cretaceous strata of Sites 801 and 800. This survey complements and summarizes the shipboard observations (Shipboard Scientific Party, 1990b, 1990c) and supplements the meager record provided by the poor core recovery with logging analyses (especially Formation MicroScanner resistivity imagery described by Molinie and Ogg, this volume). For each major time interval, corresponding to significant facies shifts observed in Site 801, comparison is made to coeval sediments at other Pacific sites and circum-Pacific outcrops in order to construct a general global framework for Leg 129 stratigraphy. Through this procedure, we raise some important questions about the Jurassic and Early Cretaceous sedimentation processes and paleoceanography.

\section{GEOLOGICAL SETTING}

Sediments of Jurassic and Early Cretaceous age have been recovered at several DSDP and ODP sites in the Pacific (Fig. 1 and Table 1). This array of sites incorporates a variety of oceanic features with varying subsidence histories. In order to determine patterns in sedimentation with respect to paleolatitude and water depth for these sites, we will examine the plate tectonic framework and regional topographic complications, estimate the paleolatitudes, and compute approximate subsidence curves. This background data will enable compilation of the sediment facies vs. time for the western Pacific in a paleolatitude and paleodepth reconstruction.

\section{Plate Tectonic Framework}

In the western Pacific Ocean, east of the Mariana Islands stretches the "Jurassic Quiet Zone," an approximately 2000-km-diameter expanse devoid of significant linear magnetic anomalies (Fig. 1). A Middle Jurassic age for oceanic crust in the northwest corner of this Quiet Zone was documented at Site 801 (Shipboard Scientific Party, 1990c).

\section{Ridge Configuration and Oceanic Plateaus}

This region is bounded by three sets of Mesozoic magnetic lineations (Larson and Chase, 1972; Handschumacher et al., 1988): the Japanese series extending to the northwest, the Hawaiian series extending to the northeast, and the Phoenix series extending to the south.

The Hawaiian set of numbered lineations and associated magneticblock model is the standard for the Late Jurassic-Early Cretaceous magnetic polarity time scale (Larson and Pitman, 1972; Larson and Hilde, 1975). The Decade of North American Geology (DNAG) time scale, which will be used in this paper, is derived from the calibration of this magnetic polarity pattern to fossiliferous magnetostratigraphic sections (e.g., Lowrie et al., 1980; Ogg et al., 1984; Lowrie and Ogg, 1986), combined with a few radiometric dates on associated stage boundaries and the simplifying assumption of a constant regular spreading rate for formation of this Hawaiian lineation "M-sequence" (Kent and Gradstein, 1985; Palmer, 1983; see version in Shipboard Scientific Party, 1990a).

The Japanese magnetic lineations have been drilled to oceanic basalt basement at Site 304 on M9r and Site 303A on M4n and the Hawaiian lineations at Site 307 on M21n (Larson, Moberly, et al., 1975) and Site 464 on Hess Rise just beyond M0 (Shipboard Scientific Party, 1981b); the basal sediment ages at these sites are consistent with the current magnetic polarity time scale (Table 1).

The Phoenix set of lineations lack a continuous pattern equivalent to the full M0-M25 of the Hawaiian standard. Except for Site 166, which documented a Hauterivian-Barremian age for anomaly M8n (Winterer et al., 1973), the Phoenix magnetic lineations have not yet been agedocumented by drilling. However, the Magellan Rise at the eastern edge of the Phoenix set yielded a Valanginian basal sediment age at Site 167 (Shipboard Scientific Party, 1973a), consistent with the correlation of the nearby intersecting magnetic anomaly as M11 (Table 1 ).

Table 1. Pacific sites examined for Jurassic and Lower Cretaceous stratigraphy (listed in order of oldest sediment recovered).

\begin{tabular}{|c|c|c|c|c|c|c|c|c|c|c|}
\hline \multirow[b]{2}{*}{ Leg } & \multirow[b]{2}{*}{ Site or Hole } & \multirow[b]{2}{*}{$\begin{array}{l}\text { Geographic } \\
\text { location }\end{array}$} & \multirow[b]{2}{*}{$\begin{array}{l}\text { Present } \\
\text { position }\end{array}$} & \multirow[b]{2}{*}{$\begin{array}{c}\text { Water } \\
\text { depth } \\
(m)\end{array}$} & \multirow[b]{2}{*}{$\begin{array}{l}\text { Age of oldest } \\
\text { sediment }\end{array}$} & \multirow[b]{2}{*}{$\begin{array}{c}\text { Sediment } \\
\text { depth } \\
\text { (mbsf) }\end{array}$} & \multicolumn{3}{|c|}{ Oceanic crustal age } & \multirow[b]{2}{*}{$\begin{array}{c}\text { Total depth } \\
\text { to basement } \\
\text { (mbsf) }\end{array}$} \\
\hline & & & & & & & $\begin{array}{l}\text { Magnetic } \\
\text { anomaly }\end{array}$ & Geologic age & Ma & \\
\hline 129 & $801 \mathrm{~B}$ & Pigafetta Basin & $18.6^{\circ} \mathrm{N} .156 .4^{\circ} \mathrm{E}$ & 5674 & Callovian-Bathonian & 462 (to crust) & pre-M33 & latest Bathonian & 170 & 462 \\
\hline 32 & 307 & ${ }^{\mathrm{b}}$ Hawaiian & $28.6^{\circ} \mathrm{N} .161 .0^{\circ} \mathrm{E}$ & 5696 & late Tithonian? & 300 (to crust) & $\mathrm{M} 2 \mathrm{ln}$ & middle Tithonian & 149 & 300 \\
\hline 32 & 306 & Shatsky Rise & $31.9^{\circ} \mathrm{N} .157 .5^{\circ} \mathrm{E}$ & 3405 & Berriasian? & 475 & M20? & middle Tithonian & 148 & 550 \\
\hline 129 & $800 \mathrm{~A}$ & Pigafetta Basin & $21.9^{\circ} \mathrm{N}, 152.3^{\circ} \mathrm{E}$ & 5686 & Berriasian? & 498 & M33 & latest Callovian? & 163 & 550 \\
\hline 17 & 167 & Magellan Plateau & $7.1^{\circ} \mathrm{N}, 183.2^{\circ} \mathrm{E}$ & 3166 & late Berriasian & 1172 (to crust) & MI6? & late Berriasian & 140 & 1172 \\
\hline 20 & 196 & 'Japanese & $30.1^{\circ} \mathrm{N}, 148.6^{\circ} \mathrm{E}$ & 6184 & earliest Cretaceous & 370 & $\mathrm{M} 24$ & early Oxfordian & 155 & 900 \\
\hline 32 & $303 \mathrm{~A}$ & Japanese & $40.8^{\circ} \mathrm{N}, 154.4^{\circ} \mathrm{E}$ & 5609 & Hauterivian-Barremian & 285 (to crust) & M4n & early Barremian & 126 & 285 \\
\hline 32 & 304 & ${ }^{\mathrm{b}}$ Japanese & $39.3^{\circ} \mathrm{N}, 155.1^{\circ} \mathrm{E}$ & 5630 & Hauterivian-Barremian & 335 (to crust) & $\mathrm{M} 9 \mathrm{r}$ & early Hauterivian & 129 & 335 \\
\hline 32 & 305 & Shatsky Rise & $32.0^{\circ} \mathrm{N} .157 .8^{\circ} \mathrm{E}$ & 2903 & Barremian & 641 & $\mathrm{M} 20$ ? & middle Tithonian & 148 & 800 \\
\hline 62 & 463 & Mid-Pacific Mountains & $21.4^{\circ} \mathrm{N} .174 .6^{\circ} \mathrm{E}$ & 2525 & Barremian & 822 & M4? & early Barremian & 126 & 900 \\
\hline 62 & 464 & North Hess Rise & $39.9^{\circ} \mathrm{N}, 173.9^{\circ} \mathrm{E}$ & 4670 & late Aptian & 308 (to crust) & Quiet zone & middle Cretaceous & 115 & 308 \\
\hline 60 & 460 & $\begin{array}{l}\text { Mariana Trench } \\
\text { (inner wall) }\end{array}$ & $17.7^{\circ} \mathrm{N} .147 .6^{\circ} \mathrm{E}$ & 6452 & $\begin{array}{l}\text { redeposited Early } \\
\text { Cretaceous }\end{array}$ & 100 & $\mathrm{M} 23$ & $\begin{array}{l}\text { middle Oxfordian } \\
\text { (subducting) }\end{array}$ & $\mathrm{n} / \mathrm{a}$ & $\mathrm{n} / \mathrm{a}: 700$ ? \\
\hline
\end{tabular}

Notes: Statistics are primarily from the corresponding site chapters (Shipboard Scientific Party, 1973a, 1973b. 1975a, 1975b. 1975c. 1975d, 1975e. 1981. 1982, 1990b. 1990c). Geological and magnetic anomaly ages are converted to Ma following the Leg 129 time scale (Shipboard Scientific Party, 1990a), which incorporates the DNAG time scale (Kent and Gradstein. 1985; Palmer, 1983) and magnetic anomaly age assignments according to Ogg et al. (1991). In cases where oceanic crust was not drilled, depth to crust is from the seismic interpretation in the corresponding site chapters, or estimated from crustal age and apparent sedimentation rates. Oldest sediments at Site 305 are Barremian according to Matter et al. (1975). Basal sediment at Site 307 is possibly upper Tithonian according to Baumgartner's (1984) calibration of the radiolarian zone. Lowest recovered sediment at Site 167 is assigned a late Berriasian age according to the apparent mixture of Tithonian and late Berriasian nannofossils (Roth, 1973; with nannofossil ranges from Ogg et al., 1991), and in accordance to the possible crustal ages according to intersecting magnetic anomalies. Oceanic crustal ages are according to the drilled magnetic anomaly, except for the Shatsky Rise and Mid-Pacific Mountains, where the age is based upon projections of magnetic anomalies (Sager et al.. 1988: Larson, 1976); these latter interpretations are uncertain (e.g.. alternative age assignment for Mid-Pacific Mountains by Winterer and Metzler, 1984). Site 460A on the inner wall of the Mariana Trench recovered a debris flow containing small clasts of calpionellid-bearing chalk (Shipboard Scientific Party, 1982; Azéma, 1982); the original setting is not known.

"From Initial Reports or estimated.

${ }^{\mathrm{b}}$ Magnetic lineation. 
The only existing remnant of the ancient Jurassic-Early Cretaceous Pacific was a small triangular microplate bounded and being enlarged by these three spreading centers, which we shall refer to as the Japanese, Hawaiian, and Phoenix ridges. There was a complex evolving set of plates (Kula, Farallon, Izanagi I and II, Shatsky, Bellingshausen, Nazca, etc.) on the opposing sides and intersections of these ridges.

The intersections of these three spreading centers tended to be unstable and remain poorly understood. The Phoenix-Japanese ridge junction is concealed beneath the Ontong Java Plateau of middle Cretaceous age (Tarduno et al., 1991) and the Caroline Rise of Tertiary age, both of which may also represent mantle plumes.

The Japanese-Hawaiian junction is partially marked by the Shatsky Rise, which was drilled at Sites 305 and 306 . Shatksy Rise may represent a hotspot outpouring in association with the triple junction (Sharman and Risch, 1988; Sager et al., 1988, and references therein; Nakanishi et al., 1989). The trend of Shatksy Rise is not linear, which may be an artifact of the triple junction moving back and forth across a hotspot (E. L. Winterer, pers. comm., 1991). If the Shatsky Rise was produced by a fixed hotspot near the triple junction and if the preserved rise was extruded onto the Pacific Plate, then the Pacific Plate from the Tithonian (M21) through Valanginian (M11) was moving to the southsouthwest with a velocity equal to the rate of ridge-spreading.

The Hawaiian-Phoenix ridge junction was associated with a complex set of short-lived ridge segments with irregular or migrating orientations and a short-lived Magellan Rise microplate (e.g., Larson, 1976; Tamaki and Larson, 1988). A "Stealth microplate" may have been active in the vicinity during the Kimmeridgian through Valanginian (Larson and Sager, this volume). The ages and tectonic cause of the nearby Mid-Pacific Mountains is uncertain, and Site 463 did not reach basement to constrain existing models. A hotspot trace for the Mid-Pacific Mountains (Winterer and Metzler, 1984) would imply that the Pacific Plate was moving to the west-southwest during a portion of the latest Jurassic or Early Cretaceous. The volcanoes of the Mid-Pacific Mountains appear to be much younger than most of the Shatsky Rise, and the part of Shatsky Rise corresponding to the MidPacific Mountain volcanism is very weakly defined (E. L. Winterer, pers. comm., 1991). Therefore, it is possible that the Shatsky Rise trend records a southward motion of the Pacific Plate during the Tithonian-earliest Cretaceous, followed by westward motion as seen in the Mid-Pacific Mountain trend. This general motion of the Pacific Plate is consistent with the limited paleomagnetic and seamount magnetization data, as discussed below.

\section{Tectonic Disruptions and Reorganizations}

Other than the major oceanic plateaus formed in the vicinity of ridge junctions (Shatsky Rise, Mid-Pacific Mountains, Magellan Rise), the ancient Pacific Plate apparently had no important populations of seamounts or linear island chains during the Jurassic. The present abundance of seamounts in the western Pacific primarily represent a dramatic pulse of mid-plate volcanism and hotspot traces during the middle Cretaceous and Late Cretaceous, with a second pulse during the Eocene. The extensive middle Cretaceous volcanism (Schlanger et al., 1981; Larson, 1991a, 1991b; Larson and Olson, 1991) resulted in concealment of the ancient Pacific oceanic crust beneath volcanic edifices, oceanic plateaus, seamount aprons, igneous sills, and submarine basalt flows. Prior to this volcanic activity, which appears to have been initiated in the Barremian-Aptian, the oceanic floor away from the few oceanic plateaus appears to have had very subdued relief; turbidite or debris flow deposits are very rare within any of the Jurassic or Lower Cretaceous sediments at most sites. At the end of the Albian, formation of a broad regional "Darwin Rise" swell of much of the Jurassic-Early Cretaceous seafloor was accompanied by a second pulse of island chain volcanism, the exposure and erosion of rudist reefs, and reorganization of Pacific Plate boundaries (Menard, 1984; McNutt et al., 1990; Winterer, 1991).
During the Late Jurassic and Early Cretaceous, three major plate tectonic reorganizations occurred in the Pacific. These events are recognized through a widespread reorientation of spreading directions and the onset or termination of volcanic activity. A change in relative spreading rates of the Japanese or the Hawaiian ridge or both may have occurred at magnetic polarity chron M25 (Nakanishi et al., 1989). The earliest well-documented reorganization occurs in the middle Tithonian, at about magnetic anomaly M21 to M20. In the vicinity of the small Pacific Plate, the middle Tithonian event resulted in an eastward jump of the Japanese-Hawaiian ridge-junction and onset of Shatsky Rise plateau-building (Handschumacher et al., 1988; Sager et al., 1988, Nakanishi et al., 1989). Paleomagnetic data indicates that the Pacific Plate also underwent a middle Tithonian reversal in direction of paleolatitude drift from northward to southward (Fig. 3; Steiner and Wallick, this volume; B. Wallick, unpubl. data, 1992).

The next major event was in the middle Valanginian, at about magnetic anomaly M11-M10N (e.g., Tamaki et al., 1979; Tamaki and Larson, 1988). The middle Valanginian activity included termination of the Shatsky Rise volcanism (Sager et al., 1988), clockwise rotation of segments of the Hawaiian spreading center (Larson and Hilde, 1975), initiation of a possible extension of a Pacific ridge as the Indian plate separated from the Australian margin of Gondwana (Larson, 1977; Fullerton et al., 1989), and apparent eastward extension of the main Phoenix spreading center terminating the brief activity of the Magellan Rise microplate (Tamaki and Larson, 1988).

The last major event occurred in the early Aptian, or at about M0. During the early Aptian, when volcanic activity was initiated throughout the existing Pacific Plate, the drift of the Pacific Plate shifted dramatically from southward to northward, the rates of global seafloor spreading were accelerated, and the spreading centers probably underwent a major reorientation.

During the Middle Jurassic, the Pacific Plate may have recorded two other events: a Bajocian-Bathonian reorganization that resulted

\section{LEGEND}

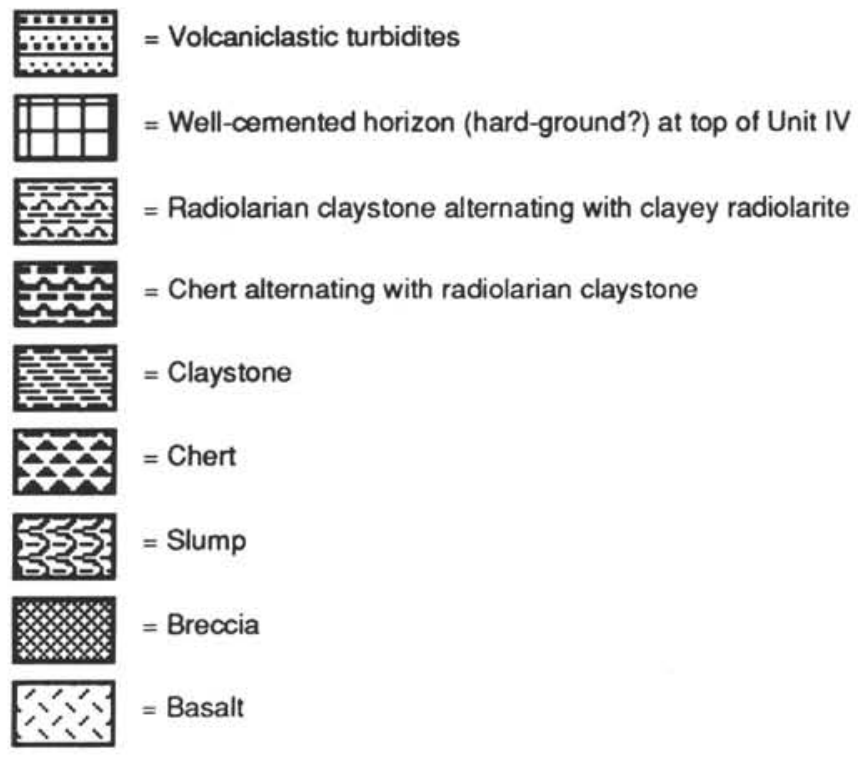

Figure 2. Jurassic through Lower Cretaceous stratigraphy of Hole 801B. Lithologic Units and biostratigraphic ages are according to the Site 801 shipboard stratigraphy (Shipboard Scientific Party, 1990c). Lithology column, depth and nature of facies contacts, and corresponding lithostratigraphic subunits are based upon the Formation MicroScanner imagery (Molinie and Ogg, this volume) and upon the limited shipboard recovery. 


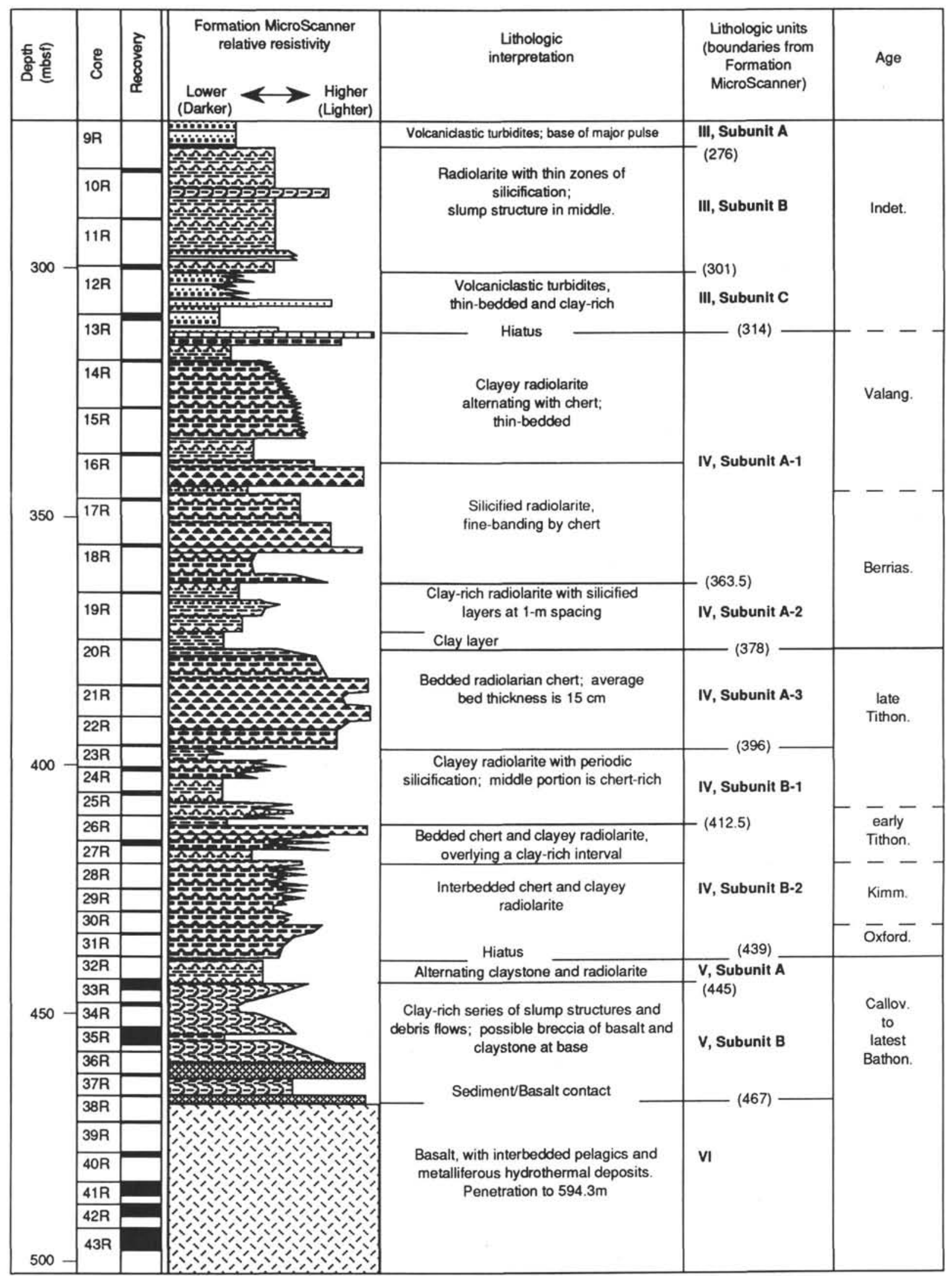

Figure 2 (continued). 


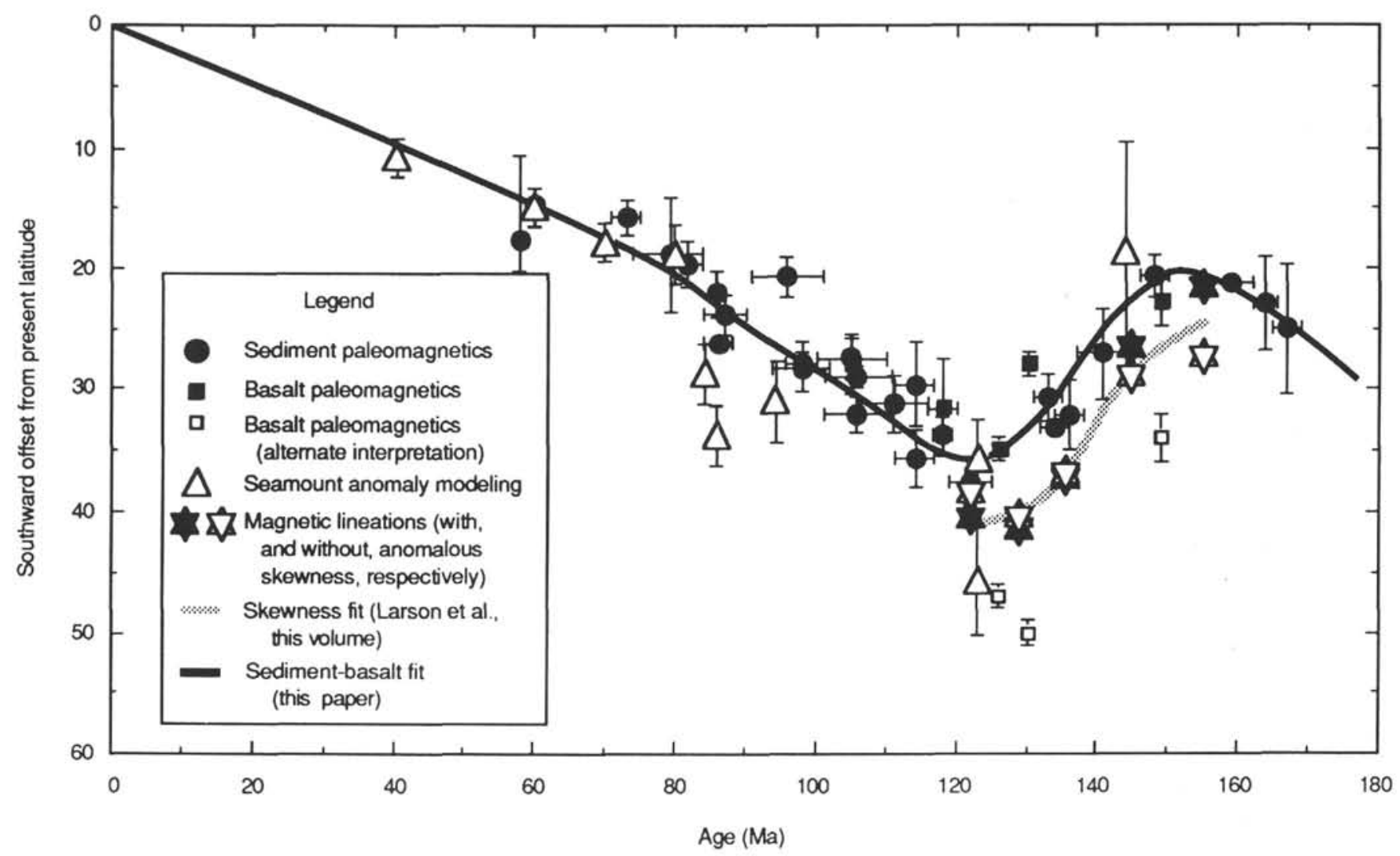

Figure 3. Paleolatitude motion of the western Pacific. Paleolatitudes, from Tables 3 and 4, are displayed as cumulative southward offset of the Leg 129 region with respect to present latitudes. Poles computed from modeling magnetic anomalies of seamounts or skewness of magnetic anomalies are applied to project the paleolatitude offset of Site 801 (Table 3). Paleolatitudes determined from skewness of Late Jurassic and Early Cretaceous M-sequence magnetic lineations are shown with and without anomalous skewness solutions; computed paleolatitudes have standard deviations ranging from $1^{\circ}$ to $2^{\circ}$ (from Larson and Sager, this volume). The preferred skewness-derived paleolatitude curve is shown in gray (from Larson et al., this volume). A generalized visual fit of the data, with emphasis on sediment and basalt paleomagnetic measurements, is displayed by the thick line. During the Callovian through middle Tithonian, the Pacific Plate drifted northward as indicated by paleomagnetic data from Site 801 (Steiner and Wallick, this volume; B. Wallick, unpubl. data, 1992; Table 4). From middle Tithonian through Barremian, the plate drifted southward, then drifted northward during the Late Cretaceous and Tertiary.

in the disruption of a triple junction and birth of the triangular embryonic Pacific Plate (Handschumacher et al., 1988), and a Callovian-Oxfordian boundary event that left its mark as a near-global sedimentation hiatus, displayed at Site 801 by a hiatus and disconformity. It is not possible to identify changes in spreading rates associated with these plate reorganization events in the western Pacific, because the DNAG time scale is based on the assumption of constant spreading rates in this region.

The Pacific was not alone in experiencing such major tectonicvolcanic disruptions. The Atlantic also experienced coeval changes in spreading rates and directions or new rift activity at M21 (middle Tithonian), M10N (Valanginian) and M0 (earliest Aptian) (Klitgord and Schouten, 1986; Sundvik and Larson, 1988). The BajocianBathonian initiation of Atlantic seafloor spreading is coincident with the birth of the Pacific Plate. These plate tectonic reorganizations are often reflected in oceanic sedimentation; for example, the widespread Paleocene-Eocene plate reorganization at $57 \mathrm{Ma}$ (chron $\mathrm{C} 24 \mathrm{R}$ ) coincides with a burst of metalliferous (hydrothermal) flux and decrease of eolian flux into Pacific sediments (Olivarez and Owen, 1989; Rea et al., 1990). In addition, major volcanic episodes, such as in the early Aptian, had global impacts through increased levels of atmospheric carbon dioxide, increased dissolution of carbonate in the oceans, climatic warming and slowing of atmosphericocean circulation, and increased organic-matter preservation (Sheridan, 1983; Arthur et al., 1985).

\section{Paleolatitude History}

\section{Seamount, Paleomagnetic, and Magnetic Lineation Skewness Databases}

During the Late Cretaceous through Eocene, the Pacific Plate drifted north (the Emperor Seamount trend), then changed at about $40 \mathrm{Ma}$ to a northwest direction of drift (the Hawaiian Island trend). Magnetization of seamounts of known ages have enabled definition of much of this Late Cretaceous to Eocene drift of the Pacific Plate (Sager and Pringle, 1988; Table 2; Fig. 3), indicating that the western Pacific was about $30^{\circ}$ farther to the south in the middle Cretaceous. Paleomagnetism of Tertiary and latest Cretaceous sediments and basalts recovered at various DSDP and Leg 129 sites yield inclinations and corresponding paleolatitudes generally consistent in trend with those obtained from modeling seamount magnetizations (Table 3; Fig. 3).

In contrast, comparison of seamount-pole vs. sediment-basalt databases for the Aptian through Santonian (Table 3; Fig. 3) suggests that the drift curve generated by modeling seamount magnetizations may overestimate the amount of total displacement of the western Pacific by about $6^{\circ}-8^{\circ}$. For example, paleomagnetic data from Santonian volcaniclastics at Site 802 indicate a $11.5^{\circ} \mathrm{S}$ paleolatitude (Shipboard Scientific Party, 1990d; B. Wallick, unpubl. data, 1992), consistent with the Santonian paleolatitude of Site 800 (Table 4) but contrasting with the $18^{\circ} \mathrm{S}$ paleolatitude predicted from the Santonian seamount- 
Table 2. Apparent positions of the North Pole through time as recorded by paleomagnetism of seamounts.

\begin{tabular}{lccccc}
\hline \multicolumn{1}{c}{$\begin{array}{c}\text { Geologic age } \\
\text { (magnetic anomaly) }\end{array}$} & $\begin{array}{c}\text { Age } \\
\text { as published } \\
(\mathrm{Ma})\end{array}$ & Pole position & $\begin{array}{c}\text { Uncertainty } \\
\text { on latitude }\end{array}$ & $\begin{array}{c}\text { Southward offset } \\
\text { implied for Site 801 }\end{array}$ & Reference \\
\hline latest Eocene & 39 & $77.6^{\circ} \mathrm{N}, 7.6^{\circ} \mathrm{E}$ & $2.4^{\circ}$ & $10.7^{\circ}$ & Sager and Pringle (1988) \\
late Maastrichtian (A30) & 66 & $69.7^{\circ} \mathrm{N}, 7.3^{\circ} \mathrm{E}$ & $2.3^{\circ}$ & $17.6 \hat{\mathrm{E}}$ & Sager and Pringle (1988) \\
middle Campanian (A33n) & 76 & $69.7^{\circ} \mathrm{N}, 1.1^{\circ} \mathrm{E}$ & $2.9^{\circ}$ & $18.6 \hat{\mathrm{E}}$ & Sager and Pringle (1988) \\
Santonian-Campanian (A33r) & 82 & $58.4^{\circ} \mathrm{N}, 359.0^{\circ} \mathrm{E}$ & $2.7^{\circ}$ & $29.4 \hat{\mathrm{E}}$ & Sager and Pringle (1988) \\
middle Santonian & 85 & $55.9^{\circ} \mathrm{N}, 331.2^{\circ} \mathrm{E}$ & $3.6^{\circ}$ & 34.0 É & Sager and Pringle (1988) \\
middle Cenomanian & 94 & $58.6^{\circ} \mathrm{N}, 329.1^{\circ} \mathrm{E}$ & $6.2^{\circ}$ & $31.2 \hat{\mathrm{E}}$ & Sager and Pringle (1988) \\
"Barremian" & $120 ?$ & $41.4^{\circ} \mathrm{N}, 317.5^{\circ} \mathrm{E}$ & $\sim 5^{\circ}$ & $46.1 \hat{\mathrm{E}}$ & Sager (1987) \\
"Early Cretaceous" & $120 ?$ & $53.8^{\circ} \mathrm{N}, 336.4^{\circ} \mathrm{E}$ & $6^{\circ}$ & $36.0 \hat{\mathrm{E}}$ & Gordon (1990) \\
"Tithonian" & $140 ?$ & $70.0^{\circ} \mathrm{N}, 315.0^{\circ} \mathrm{E}$ & $\sim 10^{\circ}$ & $18.8 \mathrm{E}$ & Sager (in press) \\
\hline
\end{tabular}

Notes: Apparent polar wander path from Tertiary to middle Cretaceous is approximately through the Greenland-Norwegian Sea to near Scotland, a middle Cretaceous arc to the south of Iceland and Greenland, and possibly a latest Jurassic-earliest Cretaceous trend through Greenland. The "Barremian" pole is mainly derived from two seamounts having uncertain ages of "pre-M0" (Sager, in press). The generalized "Tithonian" pole is suggested by pre-M0 seamounts in the Japan area with gravity signatures consistent with ages not significantly younger than underlying magnetic anomalies (Sager, in press). The corresponding motion of the Mesozoic Pacific Plate would be a southward drift during the Early Cretaceous, then a northward drift during the Late Cretaceous and Tertiary, with an oscillatory rotation of less than $20^{\circ}$ in declination. Component of east-west motion cannot be determined by paleomagnetism. Ages cited by Sager and Pringle (1988) are largely derived from dredged rocks from the seamounts having radiometric dating or from biostratigraphy converted to Ma using time scale of Harland et al. (1982). These dredges ages may be significantly younger (up to $7 \mathrm{~m} . \mathrm{y}$.) than the age of the main shield volcano and associated magnetic anomaly (Pringle et al., 1991).

derived curve. Other explanations for the apparent mismatch of some western Pacific paleomagnetic and seamount data include (1) extreme inclination shallowing in some Pacific sediments (Gordon, 1990), (2) a later tectonic shifting of the northeastern Pacific, which contains most of the seamount population of post-M0 age, northward with respect to the western Pacific (discussed in Gordon, 1982), (3) dredged summit ages on seamounts being up to $7 \mathrm{~m}$.y. younger than the age of the main shield volcano and associated magnetic anomaly (Pringle et al., 1991), (4) induced magnetization contributing to the magnetic anomaly of the seamount (Gee et al., 1989), and (5) improper techniques of modeling seamount magnetization (Parker,
1988, 1991). In the western Pacific, comparison of independent paleomagnetic analyses of Aptian-Albian sediments (Sites 585, 800, 801 , and 802) and basalts (Sites 462 and 802 ) yield approximately the same paleolatitudes (Tables 3, 4; Shipboard Scientific Party, 1985; Ogg, 1986; Wallick and Steiner, this volume; B. Wallick, unpubl. data, 1992), which suggests that a systematic bias of sediment inclinations is unlikely.

Seamounts with documented formation prior to the middle Cretaceous are rare, but indicate a possible southward direction of drift (Sager, in press). These pre-Aptian poles were derived from poorly dated seamounts from this same western Pacific region. Sager (in

Table 3. Paleolatitude motion of the Mesozoic Pacific Plate (from paleomagnetic measurements at DSDP sites and from modeling of seamount magnetization and magnetic lineation skewness).

\begin{tabular}{lccccc}
\hline \multicolumn{1}{c}{ Geologic age } & $\begin{array}{c}\text { Mean age } \\
\text { (Ma; DNAG scale) }\end{array}$ & $\begin{array}{c}\text { Southward } \\
\text { offset of } \\
\text { Pacific Plate }\end{array}$ & $\begin{array}{c}\text { Standard } \\
\text { deviation }\end{array}$ & $\begin{array}{c}\text { Type } \\
\text { of data }\end{array}$ & Reference \\
\hline late Eocene & 40 & $11^{\circ}$ & $2^{\circ}$ & Seamount & Sager and Pringle (1988) \\
Paleocene & 60 & $15^{\circ}$ & $-2^{\circ}$ & Sediment & Ogg (1986) \\
late Maastrichtian & 70 & $18^{\circ}$ & $2^{\circ}$ & Seamount & Sager and Pringle (1988) \\
middle Campanian & 80 & $19^{\circ}$ & $3^{\circ}$ & Seamount & Sager and Pringle (1988) \\
Santonian/Campanian & 84 & $29^{\circ}$ & $3^{\circ}$ & Seamount & Sager and Pringle (1988) \\
Santonian & 86 & $22^{\circ}$ & $-2^{\circ}$ & Sediment & Ogg (1986) \\
middle Santonian & 86 & $34^{\circ}$ & $3^{\circ}$ & Seamount & Sager and Pringle (1988) \\
middle Cenomanian & 94 & $31^{\circ}$ & $4^{\circ}$ & Seamount & Sager and Pringle (1988) \\
Albian & 105 & $28^{\circ}$ & $-2^{\circ}$ & Sediment, basalt & Ogg (1986) \\
M0-M4 & 122 & $40.5^{\circ}, 38.3^{\circ}$ & $2^{\circ}$ & Magnetic lineations & Larson and Sager (this volume) \\
Barremian & 123 & $46^{\circ}$ & $-5^{\circ}$ & Seamount & Sager (1987) \\
Barremian & 123 & $36^{\circ}$ & $4^{\circ}$ & Seamount & Gordon (1990) \\
early Barremian (M4) & 126 & $35^{\circ}$ or $47^{\circ}$ & $1^{\circ}$ & Basalt & Larson and Lowrie (1975) \\
M5-M10n & 129 & $41.3^{\circ}, 40.5^{\circ}$ & $1.5^{\circ}$ & Magnetic lineations & Larson and Sager (this volume) \\
early Hauterivian (M9) & 130 & $28^{\circ}$ or $50^{\circ}$ & $1^{\circ}$ & Basalt & Larson and Lowrie (1975) \\
M10n-M15 & 135 & $37.3^{\circ}, 36.9^{\circ}$ & $1.5^{\circ}$ & Magnetic lineations & Larson and Sager (this volume) \\
Tithonian/Berriasian & 144 & $19^{\circ}$ & $10^{\circ}$ & Seamount & Sager (in press) \\
M16-M21 & 145 & $26.3^{\circ}, 28.7^{\circ}$ & $1^{\circ}, 1.5^{\circ}$ & Magnetic lineations & Larson and Sager (this volume) \\
middle Tithonian (M21) & 149 & $23^{\circ}$ or $34^{\circ}$ & $2^{\circ}$ & Basalt & Larson and Lowrie (1975) \\
M21-M29 & 155 & $21.5^{\circ}, 27.2^{\circ}$ & $1^{\circ}, 2^{\circ}$ & Magnetic lineations & Larson and Sager (this volume) \\
\hline
\end{tabular}

Notes: Paleolatitudes are given as the total southward deviation from the present latitude of the sites. Age in Ma is the midpoint of the sampled paleomagnetic interval, with geological ages converted according to the DNAG time scale (Kent and Gradstein, 1985; Palmer, 1983). Paleolatitudes were derived from paleomagnetism of sediments recovered at DSDP Sites 462 (statistics recalculated from Steiner, 1981a, by Shipboard Scientific Party, 1985), 585, and 585A (Ogg, 1986) and of basalts recovered at DSDP Sites 289 (Hammond et al., 1975) and 462 (as drilled on Leg 89, but incorporating statistics recalculated from the earlier data set in Steiner, 1981b, by Ogg, 1986), 303, 304 , and 307 (Larson and Lowrie, 1975). Apparent polar wander path of Table 2 was projected to Hole $801 \mathrm{~B}$ and Site 307 , the computed paleolatitudes of these sites differ by less than $1^{\circ}$. Basalts studied by Larson and Lowrie (1985) were assumed to have formed in southern latitudes, but a northern latitude position is more consistent with the rest of the data set: Site $303 \mathrm{~A}$ is presently at $40.8^{\circ} \mathrm{N}$ and formed at $5.8^{\circ} \mathrm{N}$ or S; Site 304 is presently at $39.3^{\circ} \mathrm{N}$ and formed at $11.0^{\circ} \mathrm{N}$ or S; and Site 307 is presently at $28.6^{\circ} \mathrm{N}$ and formed at $5.6^{\circ} \mathrm{N}$ or $\mathrm{S}$. M-sequence magnetic lineation poles projected to Site 801 are given with, and without, anomalous skewness solutions, respectively. 
press) suggests that his "Barremian" pole (Sager, 1987) could be biased by induced magnetism upon reversed-polarity seamounts. Gordon (1990) derived an alternate Barremian pole by combining selected paleomagnetic data with the skewness of magnetic anomalies M0 to M4 of the different lineations. Projected paleolatitudes from these two "Barremian" seamount poles differ by $10^{\circ}$. Declination changes for the western Pacific projected by these seamount-model paleomagnetic poles suggest a possible $30^{\circ}$ clockwise rotation occurred between the Barremian and Campanian-the present northpole declination at Site 801 is projected to have been oriented $\mathrm{N} 16^{\circ} \mathrm{W}$ in the Barremian (using the pole of Sager, 1987), rotating to $\mathrm{N} 12^{\circ} \mathrm{E}$ by early Campanian - followed by a slow counterclockwise rotation to the present orientation.

Skewness of M-sequence magnetic anomalies of the HawaiianJapanese-Phoenix lineations enable paleolatitudes of their formation to be computed, but the results are dependent upon whether anomalous skewness from plate rotations $\left(30^{\circ}\right.$ clockwise) or a "Stealth plate" displacing the Phoenix lineations is assumed (Larson and Sager, this volume). When projected to Site 801 (Table 3), the skewness paleolatitudes are systematically about $6^{\circ}$ southward of the corresponding sediment paleomagnetic paleolatitudes (Fig. 3). Implicit in the skewness modeling is that there is negligible induced magnetization by the present Earth's field and that there were insignificant block rotations along listric faults dipping toward the spreading ridge; either of these factors could cause a southward bias.

Paleomagnetic analysis of oceanic crust of M4, M9, and M21 age (Larson and Lowrie, 1975) yielded inclinations that could be interpreted as either north or south of the equator (Table 3). Southernlatitude origins for the M4 and M9 sites would fit the possible "Barremian" seamount-pole of Sager (in press) and are about $6^{\circ}$ to $10^{\circ}$ south of the skewness curve, but northern-latitude origins would match the well-constrained paleolatitudes derived from coeval Lower Cretaceous sediments at Sites 800 and 801 (Table 4) and would coincide with the "Barremian" pole of Gordon (1990) (Fig. 3). Similarly, a northern latitude of Site 307 of M21 age would match both the sediment-derived paleolatitudes and broad seamount-derived pole, and is close to the skewness-derived paleolatitudes (Fig. 3). Therefore, we tentatively assign these basalt inclinations to a northern paleolatitude. However, Larson (pers. comm., 1992) considers that these sites formed south of the paleoequator, and that the Site 307 area is anomalous.

Our reconstruction of the Jurassic-Early Cretaceous paleolatitude and associated sediment belts is based on the composite of paleomagnetic data from these western Pacific sites (Tables 3, 4; Fig. 3), with preference given to basalt and sediment paleomagnetic data. The composite paleolatitude trend derived from such paleomagnetic measurements also compares favorably with sedimentary and faunal evidence of the crossing of the high-fertility equator by various sites, as will be documented below.

\section{Implications of Paleolatitude Motion During Late Jurassic to Early Aptian}

A smoothed paleolatitude curve for the region was constructed from this array of paleomagnetic data and applied to the various DSDP and ODP sites (Fig. 3, Table 5). Application of this generalized curve from the Leg 129 region to other sites is uncertain due to possible rotation of the Pacific Plate or later tectonic offsets. Seamount-derived poles indicate a possible $30^{\circ}$ clockwise rotation between the Barremian to Campanian - the present north-pole declination at Site 801 is projected to have been oriented $\mathrm{N} 16^{\circ} \mathrm{W}$ in the Barremian (using the pole of Sager, 1987), rotating to $\mathrm{N} 12^{\circ} \mathrm{E}$ by early Campanianfollowed by a slow counterclockwise rotation to the present orientation. Alternative interpretations of the skewness of magnetic lineations suggest either an additional $30^{\circ}$ clockwise rotation occurred between the Kimmeridgian and Barremian, or else rotation was negligible and the Phoenix ridge was displaced southward by formation of a "Stealth plate" (Larson and Sager, this volume; Larson et al., this volume). A significant post-Early Cretaceous clockwise rotation of the early Pacific Plate would imply that paleolatitudes of sites located to the east of the Leg 129 region, such as Site 167, were further north than estimated in Table 5 .

The western Pacific drifted northward during the Middle and Late Jurassic (Callovian through mid-Tithonian). The Middle-Late Jurassic portion of this curve is not well-constrained owing to its derivation from only Site 801 sediments. During the late Tithonian through Early Cretaceous, the Pacific Plate drifted rapidly southward with an average drift rate of $4^{\circ}$ latitude per geological stage, equivalent to about $80 \mathrm{~km} / \mathrm{m} . \mathrm{y}$. $(8 \mathrm{~cm} / \mathrm{yr})$. A maximum southern position was reached during the early Aptian, followed by a northward drift through the Late Cretaceous.

The majority of sites drilled on Japanese and Hawaiian magnetic lineations of latest Jurassic and Early Cretaceous age (Sites 196, 307, $305,304,303 \mathrm{~A}$, and 464 ) originated at spreading ridges located at approximately $5^{\circ}-10^{\circ} \mathrm{N}$. These spreading ridges appeared to have remained semi-stationary with respect to the Earth's spin axis during this time interval. If the skewness-derived paleolatitude curve is used, then these portions of the ridges are computed to have remained close to the paleoequator, with a stable ridge triple junction at about $5^{\circ} \mathrm{N}$ (Larson et al., this volume). Therefore, southward-directed seafloor spreading from the semi-stationary Japanese and Hawaiian ridges was the major factor producing the apparent southward motion of this growing Pacific Plate. This conclusion also supports the formation of the Shatsky Rise at the stationary hotspot coinciding with the Japanese-Hawaiian ridge triple junction (Sager et al., 1988).

A stationary Japanese-Hawaiian ridge system and Shatsky hotspot, if valid, implies that the Pacific Plate experienced negligible east-west longitude drift with respect to the hotspot reference frame during the latest Jurassic and Early Cretaceous. Shatsky Rise displays a slight eastward angle to its northward trend, indicating that its postulated hotspot may have migrated approximately $7^{\circ}$ eastward (in present longitude coordinates) between the Tithonian and middle Valanginian. However, the seamount-derived apparent polar wander curve indicates a net clockwise rotation of $10^{\circ}-15^{\circ}$ of the Early Cretaceous Pacific Plate with respect to the present North Pole; therefore the postulated Shatsky Rise hotspot trace was trending nearly due south in paleocoordinates, indicating insignificant eastwest motion of the ancient Pacific Plate during the Early Cretaceous. It is possible that this apparent stationary position of the Hawaiian ridge may have been a factor in producing the remarkable continuity of its magnetic lineation pattern for 50 m.y.

In contrast, the opposing Phoenix ridge must have been migrating southward in latitude at a rate equal to the combined half-spreading rates of the Japanese-Hawaiian ridge system and of the Phoenix ridge. Larson and Sager (this volume) postulate that the migration of the Phoenix ridge may have been accentuated by the formation of a "Stealth" spreading center at the southern edge of the "Jurassic Quiet Zone" during latest Jurassic through Valanginian. There is not yet any paleomagnetic or seamount-pole data from the older Phoenix lineations to verify these predictions.

All sites were formed and remained in tropical latitudes between approximately $10^{\circ} \mathrm{N}$ and $15^{\circ} \mathrm{S}$ throughout the Jurassic and Early Cretaceous. As a result, our database of the sedimentation history of the mega-Pacific is restricted to environments along the Equatorial-divergence and the bordering tradewind belts. If the mega-Pacific oceanography and climate was analogous to the present Pacific climate, then we would predict increased surface-water fertility and associated microfossil productivity when sites were within approximately $5^{\circ}$ of the paleoequator, and possible increased influx of eolian dust and volcanic ash from eastern sources (the western landmasses of Pangea or Laurasia) when sites were between approximately $5^{\circ}$ and $15^{\circ}$ latitude. The relative importance of equatorial high-productivity vs. eolian 
Table 4. Paleolatitude motion of the Mesozoic Pacific Plate (from paleomagnetic measurements at Leg 129 sites).

\begin{tabular}{|c|c|c|c|c|c|}
\hline Geologic age & $\begin{array}{c}\text { Mean age } \\
\text { (Ma: DNAG scale) }\end{array}$ & $\begin{array}{l}\text { Southward offset } \\
\text { of Pacific Plate } \\
\text { (degrees) }\end{array}$ & Site & $\begin{array}{l}\text { Number of } \\
\text { samples }\end{array}$ & Comments \\
\hline late Paleocene-early Eocene & $58 \pm 1$ & $17.6 \pm 7.1$ & 802 & 6 & \\
\hline late Campanian-early Maestrictian & $73 \pm 2$ & $15.6 \pm 1.4$ & 802 & 16 & \\
\hline late Campanian & $79 \pm 5$ & $18.6 \pm 4.7$ & 802 & 4 & \\
\hline early Campanian & $82 \pm 2$ & $19.5 \pm 1.9$ & 802 & 28 & \\
\hline Coniacian-Santonian & $86 \pm 2$ & $26.0 \pm \mathrm{n} / \mathrm{a}$ & 801 & 1 & \\
\hline late Turonian-late Santonian & $87 \pm 3$ & $23.6 \pm 1.8$ & 802 & 28 & \\
\hline middle Albian-middle Cenomanian & $96 \pm 5$ & $20.6 \pm 1.7$ & 802 & 14 & \\
\hline late Albian-late Cenomanian & $98 \pm 4$ & $28.2 \pm 1.9$ & 801 & 15 & \\
\hline late Albian-early Cenomanian & $98 \pm 2$ & $28.0 \pm 1.1$ & 800 & 21 & \\
\hline late Albian-early Cenomanian & $98 \pm 2$ & $27.8 \pm 2.1$ & 801 & 13 & \\
\hline Albian & $106 \pm 5$ & $28.8 \pm 1.0$ & 800 & 8 & \\
\hline Albian & $106 \pm 5$ & $32.0 \pm 1.3$ & 801 & 35 & \\
\hline late Aptian-early Albian & $111 \pm 5$ & $31.2 \pm 2.1$ & 801 & 39 & \\
\hline late Aptian-early Albian & $114 \pm 3$ & $35.3 \pm 2.6$ & 800 & 8 & \\
\hline late Aptian-late Albian & $114 \pm 3$ & $29.4 \pm 3.6$ & 802 & 13 & \\
\hline early Aptian & $118 \pm 1$ & $33.7 \pm 1.2$ & 800 & 57 & \\
\hline early Aptian & $118 \pm 2$ & $31.5 \pm 4.0$ & 802 & 25 & Basalt \\
\hline late Barremian? & $122 \pm 3$ & $37.2 \pm 1.5$ & 800 & 39 & \\
\hline late Valanginian-early Hauterivian & $133 \pm 1$ & $30.5 \pm 2.0$ & 800 & 12 & \\
\hline late Valanginian & $134 \pm 1$ & $33.0 \pm \mathrm{n} / \mathrm{a}$ & 801 & 2 & \\
\hline early Valanginian-late Valanginian & $136 \pm 2$ & $31.9 \pm 2.9$ & 800 & 14 & \\
\hline late Berriasian-early Valanginian & $141 \pm 4$ & $26.9 \pm 3.8$ & 801 & 8 & \\
\hline middle-late Tithonian & $148 \pm 2$ & $20.4 \pm 1.7$ & 801 & 14 & \\
\hline Oxfordian & $159 \pm 3$ & $20.9 \pm \mathrm{n} / \mathrm{a}$ & 801 & 1 & \\
\hline late Callovian & $164 \pm 1$ & $22.6 \pm 3.9$ & 801 & 13 & \\
\hline early-middle Callovian & $167 \pm 2$ & $25.0 \pm 5.7$ & 801 & 5 & \\
\hline
\end{tabular}

Notes: Paleolatitudes are given as the total southward deviation from the present latitude of the sites. Paleolatitudes were computed by Brian Wallick (unpubl. data, 1992) by applying inclination statistics (method of Kono, 1980) to paleomagnetic sample suites spanning different biostratigraphic age intervals (data are displayed in Steiner and Wallick, this volume; number of samples are those having high-quality data within the selected age interval). Age in Ma is the midpoint of the sampled paleomagnetic interval, with geological ages converted according to the DNAG time scale (Kent and Gradstein, 1985; Palmer, 1983). Paleolatitude of basalts at Site 802 is from Wallick and Steiner (this volume),

influx would also depend on the proximity, configuration, and climate of these eastern continents and upon the relative strength of the tropical wind systems.

\section{Subsidence Curves}

Depth is an important factor in the preservation of pelagic sediment and in exposure to deep-water currents. Paleodepths of the studied sites were estimated following the procedure of Tucholke and Vogt (1979). A uniform thermal subsidence of underlying oceanic crust, which was assumed to have initially formed at ridge depths of $2700 \mathrm{~m}$, and of plateaus was computed by applying an empirical global curve (Parsons and Sclater, 1977, as modified by Marty and Cazenave, 1989-their "Case 2"), where Depth $=2700 \mathrm{~m}+283 \mathrm{~m} \cdot$ Velapsed m.y. Sediment loading was compensated for by raising the sediment surface above the calculated depth of oceanic crust by adding two-thirds of the total thickness of accumulated sediment (Table 5). "Forward" modeling of estimated paleodepths from an assumed $2700 \mathrm{~m}$ ridge depth was used rather than "backtracking" from present depths because of the possible distortion of post-middle Cretaceous paleodepths by the widespread Darwin Rise volcanic episode in this region (e.g., Menard, 1984; McNutt et al., 1990).

Sites on elevated plateaus were first backtracked by "unloading" the total accumulated sediment and computing the depth of the basement surface prior to thermal subsidence along the oceanic curve. This procedure assumes that any underlying older oceanic crust was thermally reset to the age of the plateau and that isostatic adjustment to the plateau loading occurred prior to sedimentation. Such a computation, despite its inaccuracies, indicates that the initial depths of sites on the Shatsky Rise and Mid-Pacific Mountains were within $400 \mathrm{~m}$ of the surface or possibly at sea level, and the Magellan Rise Site 167 was initially $700 \mathrm{~m}$ deep (Table 5).
These estimates of paleodepth are mainly for comparative purposes. Subsidence curves are only an empirical average of observed oceanic crustal depths, and individual sites and entire oceans will deviate considerably from this mean (Marty and Cazenave, 1989). The "predicted" present-age depths to sediment surface of the oceanic crust sites differ from observed by up to $700 \mathrm{~m}$ too deep (Site 801 ) to $500 \mathrm{~m}$ too shallow (Site 196), with depths at some sites (Site 304 and 303A) being exactly as predicted. Therefore, we estimate that each paleodepth for the various sites has an approximate $500 \mathrm{~m}$ uncertainty.

The typical ocean-crust site in the ancient western Pacific will be at a depth of $3200 \mathrm{~m}$ and located approximately $300 \mathrm{~km}$ from the active spreading ridge after 5 m.y. and at $3900 \mathrm{~m}$ depth and $1300 \mathrm{~km}$ from the ridge after $20 \mathrm{~m} . \mathrm{y}$. The geometry of three spreading ridges bounding the triangular Pacific Plate implies that, after its formation at the ridge crest, each ocean-crust site would have subsided into a broad mid-ocean basin. Bottom-water circulation may have been dependent upon penetration of deep water into this basin along fracture zone channels. Yet even the oldest sediments at Site 801 show no indication of low-oxygen bottom-water conditions, indicating that this ridge-bordered intra-oceanic basin maintained active deep-water circulation.

\section{General Sedimentary Facies}

The paleodepth-paleolatitude framework for each site was applied to their sediment facies and accumulations (Table 5). Sediment facies for each age interval are according to our examination of the sediment cores or are from published core descriptions in the respective Initial Reports site chapters. We will summarize these facies in the following sections.

Several preliminary observations on sedimentation patterns can be made from this compilation. 
Table 5. Geological setting and facies of sites in the Mesozoic Pacific (paleolatitude, paleodepth, sediment facies, and thickness).

\begin{tabular}{|c|c|c|c|c|c|c|c|}
\hline Geologic age & $\begin{array}{l}\text { Magnetic } \\
\text { chron } \\
\text { (Ma) }\end{array}$ & $\begin{array}{c}\text { Southward } \\
\text { offset from } \\
\text { present latitude }\end{array}$ & $\begin{array}{c}\text { Site } 801 \\
\left(18.6^{\circ} \mathrm{N}: 5674 \mathrm{~m}: 170 \mathrm{Ma}\right)\end{array}$ & $\begin{array}{c}\text { Site } 800 \\
\left(21.9^{\circ} \mathrm{N} ; 5686 \mathrm{~m}: 163 \mathrm{Ma}\right)\end{array}$ & $\begin{array}{c}\text { Site } 196 \\
\left(30.1^{\circ} \mathrm{N}, 6184 \mathrm{~m} ; 155 \mathrm{Ma}\right)\end{array}$ & $\begin{array}{c}\text { Site } 307 \\
\left(28.6^{\circ} \mathrm{N}, 5696 \mathrm{~m} ; 149 \mathrm{Ma}\right)\end{array}$ & $\begin{array}{c}\text { Site } 305 \\
\left(32.0^{\circ} \mathrm{N} ; 2903 \mathrm{~m} ; 148 \mathrm{Ma}\right) \\
(\text { initial depth }=0 \mathrm{~m})\end{array}$ \\
\hline early Callovian & JQZ (167) & $25^{\circ}$ & $\begin{array}{l}6^{\circ} \mathrm{S} ; 3200 \mathrm{~m} \\
\text { Claystonc, radiolarite; } 10 \mathrm{~m}\end{array}$ & & & & \\
\hline Oxfordian & M27 (159) & $22^{\circ}$ & $\begin{array}{l}3^{\circ} \mathrm{S}: 3600 \mathrm{~m} \\
\quad \text { Clayey radiolarite: } 15 \mathrm{~m}\end{array}$ & $\begin{array}{l}0^{\circ}: 3300 \mathrm{~m} \\
\quad \text { Unknown; } 10 \mathrm{~m}\end{array}$ & & & \\
\hline Kimmeridgian & M23 (154) & $21^{\circ}$ & $\begin{array}{l}2^{\circ} \mathrm{S}: 3800 \mathrm{~m} \\
\text { Clayey radiolarite, and hiatus: } 15 \mathrm{~m}\end{array}$ & $\begin{array}{l}1^{\circ} \mathrm{N}: 3500 \mathrm{~m} \\
\text { Unknown; } 10 \mathrm{~m}\end{array}$ & $\begin{array}{l}7^{\circ} \mathrm{N}: 2900 \mathrm{~m} \\
\text { Unknown; } 50 \mathrm{~m}\end{array}$ & & \\
\hline Tithonian & M21 (150) & $20^{\circ}$ & $\begin{array}{l}1^{\circ} \mathrm{S}: 3900 \mathrm{~m} \\
\text { Bedded chert: } 30 \mathrm{~m}\end{array}$ & $\begin{array}{l}2^{\circ} \mathrm{N}: 3700 \mathrm{~m} \\
\text { Unknown: } 10 \mathrm{~m}\end{array}$ & $\begin{array}{l}10^{\circ} \mathrm{N}: 3100 \mathrm{~m} \\
\text { Radiolarite, claystone; } 150 \mathrm{~m} \text { ? }\end{array}$ & $\begin{array}{l}9^{\circ} \mathrm{N}: 2700 \mathrm{~m} \\
\quad \text { Radiolarian claystone; } 10 \mathrm{~m}\end{array}$ & \\
\hline Berriasian & M16 (142) & $23^{\circ}$ & $\begin{array}{l}4^{\circ} \mathrm{S} ; 4100 \mathrm{~m} \\
\quad \text { Clayey radiolarite; } 40 \mathrm{~m}\end{array}$ & $\begin{array}{l}1^{\circ} \mathrm{S}: 4000 \mathrm{~m} \\
\text { Chert, radiolarite: } 20 \mathrm{~m}\end{array}$ & $\begin{array}{l}7^{\circ} \mathrm{N}: 3400 \mathrm{~m} \\
\text { Siliceous limestone: } 250 \mathrm{~m} ?\end{array}$ & $\begin{array}{l}6^{\circ} \mathrm{N}: 3400 \mathrm{~m} \\
\quad \text { Calcareous chert: } 10 \mathrm{~m}\end{array}$ & $\begin{array}{l}9^{\circ} \mathrm{N} ; 600 \mathrm{~m} \\
\text { Unknown; } 40 \mathrm{~m}\end{array}$ \\
\hline Valanginian & M12 (135) & $29^{\circ}$ & $\begin{array}{l}10^{\circ} \mathrm{S}: 4300 \mathrm{~m} \\
\text { Clayey radiolarite: } 30 \mathrm{~m}\end{array}$ & $\begin{array}{l}7^{\circ} \mathrm{S}: 4100 \mathrm{~m} \\
\text { Clayey radiolarite; } 30 \mathrm{~m}\end{array}$ & $\begin{array}{l}1^{\circ} \mathrm{N}: 3500 \mathrm{~m} \\
\text { Claystone, chert, limestone: } 100 \mathrm{~m}\end{array}$ & $\begin{array}{l}0^{\circ}: 3700 \mathrm{~m} \\
\text { Siliceous limestone: } 20 \mathrm{~m}\end{array}$ & $\begin{array}{l}3^{\circ} \mathrm{N} ; 900 \mathrm{~m} \\
\text { Unknown: } 30 \mathrm{~m}\end{array}$ \\
\hline Hauterivian & M9 (130) & $33^{\circ}$ & $\begin{array}{l}14^{\circ} \mathrm{S} ; 4400 \mathrm{~m} \\
\text { Hiatus? }\end{array}$ & $\begin{array}{l}1{ }^{\circ} \mathrm{S}: 4300 \mathrm{~m} \\
\text { Hiatus?: }<10 \mathrm{~m}\end{array}$ & $\begin{array}{l}3^{\circ} \mathrm{S} ; 3600 \mathrm{~m} \\
\text { Chert: } 50 \mathrm{~m} \text { ? }\end{array}$ & $\begin{array}{l}4^{\circ} \mathrm{S}: 3800 \mathrm{~m} \\
\text { Siliceous limestone; } 100 \mathrm{~m}\end{array}$ & $\begin{array}{l}I^{\circ} \mathrm{S} ; 1100 \mathrm{~m} \\
\text { Unknown: } 30 \mathrm{~m}\end{array}$ \\
\hline Barremian & M3 (124) & $35^{\circ}$ & $\begin{array}{l}16^{\circ} \mathrm{S}: 4500 \mathrm{~m} \\
\text { Hiatus? }\end{array}$ & $\begin{array}{l}13^{\circ} \mathrm{S}: 4400 \mathrm{~m} \\
\text { Hiatus? }\end{array}$ & $\begin{array}{l}5^{\circ} \mathrm{S}: 3800 \mathrm{~m} \\
\quad \text { Chert; } 20 \mathrm{~m} \text { ? }\end{array}$ & $\begin{array}{l}6^{\circ} \mathrm{S} ; 4000 \mathrm{~m} \\
\text { Chert: } 35 \mathrm{~m}\end{array}$ & $\begin{array}{l}3^{\circ} \mathrm{S}: 1200 \mathrm{~m} \\
\text { Siliceous limestone, porcellanite; } 40 \mathrm{~m}\end{array}$ \\
\hline early Aptian & M0 (118) & $36^{\circ}$ & $\begin{array}{l}17^{\circ} \mathrm{S}: 4600 \mathrm{~m} \\
\text { Distal volcaniclastics?: } 10 \mathrm{~m}\end{array}$ & $\begin{array}{l}14^{\circ} \mathrm{S}: 4400 \mathrm{~m} \\
\quad \text { Volcaniclastics, sill: } 170 \mathrm{~m}\end{array}$ & $\begin{array}{l}6^{\circ} \mathrm{S}: 3900 \mathrm{~m} \\
\text { Chert: } 10 \mathrm{~m} \text { ? }\end{array}$ & $\begin{array}{l}7^{\circ} \mathrm{S}: 4100 \mathrm{~m} \\
\quad \text { Volcanic ash: } 20 \mathrm{~m}\end{array}$ & $\begin{array}{l}4^{\circ} \mathrm{S}: 1400 \mathrm{~m} \\
\text { Siliceous limestone, porcellanite: } 70 \mathrm{~m}\end{array}$ \\
\hline Aptian/Albian & CQZ (113) & $34^{\circ}$ & $\begin{array}{l}15^{\circ} \mathrm{S}: 4700 \mathrm{~m} \\
\text { Clayey radiolarite?; } 20 \mathrm{~m}\end{array}$ & $\begin{array}{l}12^{\circ} \mathrm{S}: 4400 \mathrm{~m} \\
\text { Siliceous limestone; } 60 \mathrm{~m}\end{array}$ & $\begin{array}{l}4^{\circ} \mathrm{S} ; 4000 \mathrm{~m} \\
\text { Chert; } 20 \mathrm{~m} \text { ? }\end{array}$ & $\begin{array}{l}5^{\circ} \mathrm{S}: 4300 \mathrm{~m} \\
\quad \text { Siliceous claystone; } 20 \mathrm{~m}\end{array}$ & $\begin{array}{l}2^{\circ} \mathrm{S} ; 1500 \mathrm{~m} \\
\text { Siliceous limestone, porcellanite; } 40 \mathrm{~m}\end{array}$ \\
\hline
\end{tabular}

Notes: Present latitude, depth, and basement age of sites are from Table 1. Paleolatitude drift of this region of the Pacific Plate is an extrapolated curve of total southward offset from present latitudes (Fig. 3) - the plate drifted northward during the Middle Jurassic to middle Tithonian, southward through the Early Cretaceous, then northward beginning in the early Aptian - uncertainties are probably about $3^{\circ}$ for most ages. Paleolatitude for sites distant to the Leg 129 region may have been affected by rotation of the Pacific Plate (discussed in text). Depths of seafloor (depositional surface) are computed using the procedure of Tucholke and Vogt (1979), which uses the empirical subsidence curve of oceanic crust (Parsons and Sclater, 1977 , as modified by Marty and Cazenave, 1989, in their 'Case 2 ) and assumes an initial ridge crest depth of $2700 \mathrm{~m}$. hence. Depth of sediment surface $=(2700 \mathrm{~m}+283 \mathrm{~m} \cdot \mathrm{elapsed} \mathrm{m.y.})(=\mathrm{crustal}$ subsidencel $-2 / 3$ of accumulated thickness of compacted sediment. Depths of depositional surfaces on oceanic plateaus (e.g.. Sites 305. 306. and 463) were computed by the same subsidence curve, but with an appropriate initial depth according to the estimated crustal age and total sediment thickness. Results of depth calculations were rounded to the nearest $100 \mathrm{~m}$. Absolute ages (Ma) for geological stages are from the DNAG time scale (Palmer. 1983, Kent and Gradstein, 1985) with modified magnetic anomaly ages (Ogg et al., 1991). Sediment facies for each age interval are according to our examination of the cores or are according to core descriptions in the respective Initial Reports site chapters (Shipboard Scientific Party, 1973a, 1973b, 1975a, 1975b, 1975c, 1975d, 1975e, 1981, 1982, 1990b, 1990c). Sediment ages for Sites 167 and 463 are according to magnetostratigraphy (by Sayre, 1981, with M3 and M0 ages after Ogg. 1988; and by Tarduno et al., 1989). Thicknesses of sediment are tabulated as the accumulation during the time interval between the selected age horizon and the underlying age horizon or volcanic basement, and are rounded to the nearest $10 \mathrm{~m}$. If there was no penetration of older sediments, the "thicknesses" are scaled according to estimates of the depth and age of basement (Table 1)

Table 5 (continued).

\begin{tabular}{|c|c|c|c|c|c|c|}
\hline Geologic age & $\begin{array}{c}\text { Site } 306 \\
\left(31.9^{\circ} \mathrm{N} ; 3405 \mathrm{~m} ; 148 \mathrm{Ma}\right) \\
\text { (initial depth }=400 \mathrm{~m})\end{array}$ & $\begin{array}{c}\text { Site } 167 \\
\left(7.1^{\circ} \mathrm{N} .3166 \mathrm{~m}: 140 \mathrm{Ma}\right) \\
\text { (initial depth }=600 \mathrm{~m})\end{array}$ & $\begin{array}{c}\text { Site } 304 \\
\left(39.3^{\circ} \mathrm{N}: 5630 \mathrm{~m}: 129 \mathrm{Ma}\right)\end{array}$ & $\begin{array}{c}\text { Site } 303 \mathrm{~A} \\
\left(40.8^{\circ} \mathrm{N}: 5609 \mathrm{~m}: 126 \mathrm{Ma}\right)\end{array}$ & $\begin{array}{c}\text { Site } 463 \\
\left(21.4^{\circ} \mathrm{N}: 2525 \mathrm{~m}: 126 \mathrm{Ma}\right) \\
\text { (initial depth }=+50 \mathrm{~m} \text { ) }\end{array}$ & $\begin{array}{c}\text { Site } 464 \\
\left(39.9^{\circ} \mathrm{N} .4670 \mathrm{~m} ; 115 \mathrm{Ma}\right)\end{array}$ \\
\hline \multicolumn{7}{|l|}{ early Callovian } \\
\hline \multicolumn{7}{|l|}{ Oxfordian } \\
\hline \multicolumn{7}{|l|}{ Kimmeridgian } \\
\hline \multicolumn{7}{|l|}{ Tithonian } \\
\hline Berriasian & $\begin{array}{l}9^{\circ} \mathrm{N}: 1000 \mathrm{~m} \\
\text { Siliceous limestone; } 40 \mathrm{~m}\end{array}$ & & & & & \\
\hline Valanginian & $\begin{array}{l}3^{\circ} \mathrm{N} ; 1300 \mathrm{~m} \\
\text { Siliceous limestone; } 70 \mathrm{~m}\end{array}$ & $\begin{array}{l}12^{\circ} \mathrm{S}: 1000 \mathrm{~m} \\
\text { Siliceous limestone: } 60 \mathrm{~m}\end{array}$ & & & & \\
\hline Hauterivian & $\begin{array}{l}1^{\circ} \mathrm{S}: 1400 \mathrm{~m} \\
\text { Siliceous limestone; } 70 \mathrm{~m}\end{array}$ & $\begin{array}{l}16^{\circ} \mathrm{S}: 1300 \mathrm{~m} \\
\quad \text { Siliceous limestone; } 120 \mathrm{~m}\end{array}$ & $\begin{array}{l}6^{\circ} \mathrm{N}: 2700 \mathrm{~m} \\
\text { Chert, calcareous clay: } 10 \mathrm{~m}\end{array}$ & & & \\
\hline Barremian & $\begin{array}{l}3^{\circ} \mathrm{S}: 1600 \mathrm{~m} \\
\quad \text { Calcareous porcellanite; } 100 \mathrm{~m}\end{array}$ & $\begin{array}{l}18^{\circ} \mathrm{S} ; 1500 \mathrm{~m} \\
\text { Siliceous limestone; } 60 \mathrm{~m}\end{array}$ & $\begin{array}{l}4^{\circ} \mathrm{N}: 3300 \mathrm{~m} \\
\text { Chert, clay: } 40 \mathrm{~m}\end{array}$ & $\begin{array}{l}6^{\circ} \mathrm{N}: 3000 \mathrm{~m} \\
\text { Chert, calcareous clay: } 10 \mathrm{~m}\end{array}$ & $\begin{array}{l}14^{\circ} \mathrm{S}: 300 \mathrm{~m} \\
\text { Siliceous limestone: } 60 \mathrm{~m}\end{array}$ & \\
\hline early Aptian & $\begin{array}{l}4^{\circ} \mathrm{S}: 1700 \mathrm{~m} \\
\text { Calcareous porcellanite; } 60 \mathrm{~m}\end{array}$ & $\begin{array}{l}19^{\circ} \mathrm{S}: 1700 \mathrm{~m} \\
\text { Volcanic ash; } 30 \mathrm{~m}\end{array}$ & $\begin{array}{l}3^{\circ} \mathrm{N}: 3600 \mathrm{~m} \\
\text { Chert: } 40 \mathrm{~m}\end{array}$ & $\begin{array}{l}5^{\circ} \mathrm{N}: 3500 \mathrm{~m} \\
\text { Chert, clay: } 30 \mathrm{~m}\end{array}$ & $\begin{array}{l}15^{\circ} \mathrm{S}: 600 \mathrm{~m} \\
\text { Siliceous limestone, volcanic ash; } 190 \mathrm{~m}\end{array}$ & \\
\hline Aptian/Albian & $\begin{array}{l}2^{\circ} \mathrm{S} ; 1800 \mathrm{~m} \\
\quad \text { Calcareous porcellanite; } 40 \mathrm{~m}\end{array}$ & $\begin{array}{l}17^{\circ} \mathrm{S} ; 1800 \mathrm{~m} \\
\text { Siliceous clayey limestone?; } 20 \mathrm{~m}\end{array}$ & $\begin{array}{l}5^{\circ} \mathrm{N}: 3800 \mathrm{~m} \\
\text { Hiatus?- } 10 \mathrm{~m}\end{array}$ & $\begin{array}{l}6^{\circ} \mathrm{N}: 3800 \mathrm{~m} \\
\text { Hiatus? }\end{array}$ & $\begin{array}{l}13^{\circ} \mathrm{S}: 800 \mathrm{~m} \\
\text { Siliceous limestone: } 100 \mathrm{~m}\end{array}$ & $\begin{array}{l}6^{\circ} \mathrm{N}: 3100 \mathrm{~m} \\
\text { Chert. calcareous clay } 30 \mathrm{~m}\end{array}$ \\
\hline
\end{tabular}


1. The characteristic sediment in the tropical Pacific is radiolarianrich, regardless of age or paleodepth.

2. Carbonate-bearing pelagic sediment, in the form of siliceous limestone, is not preserved until the Berriasian (Sites 196, 307, 306) and occurs at depths shallower than $3400 \mathrm{~m}$. Coeval sites deeper than $3900 \mathrm{~m}$ (Sites 801 and 800 ) did not preserve any significant carbonate, even if they were at a similar latitudinal distance from the equator. The carbonate compensation depth (CCD) for this tropical region remained at approximately $3500 \mathrm{~m}$ during the earliest Cretaceous. Accumulation rates of siliceous limestone on shallow oceanic plateaus (Sites 305, $306,167,463$ ) are only slightly faster than accumulation rates at oceanic-crust depths on oceanic crust (Sites 196 and 307).

3. Passage of a site under the equatorial high-fertility zone is mainly expressed as an increased abundance of radiolarians. During the Tithonian, proximity to the equator is recorded as a facies of bedded radiolarian cherts (Site 801 and possibly Site 800 ). During the remainder of the Early Cretaceous, the equator crossings by oceaniccrust sites consist of an accelerated sedimentation of siliceous limestone, which appears to have a greater chert content than the preceding or succeeding facies deposited further from the equator (Lancelot and Larson, 1975; Lancelot, 1978).

4. Accumulations are about 30 to $60 \mathrm{~m}$ of sediment per geological stage during the Early Cretaceous, implying average sedimentation rates of about $5-10 \mathrm{~m} / \mathrm{m}$.y. Sites lacking calcareous sediments (Sites 801 and 800 ) have slightly lower accumulation rates. Passage under the paleoequator or arrival of significant volcanic detritus accelerated sedimentation rates. The Aptian stage displays much slower estimated sedimentation rates of pelagic sediment components, typically only 20 to $40 \mathrm{~m}$, perhaps indicating a decline in productivity or carbonate preservation.

5. The early Aptian had an abundance of volcanism, recorded as volcanic ash layers (Sites 167, 463, 307), volcaniclastics (Sites 800 and 801?; plus Sites 802 and 585 in the Mariana Basin), and injection of volcanic sills (Site 800). However, some sites near the equator during the early Aptian did not record significant volcanic activity (Sites 196, 305, 306, 304); perhaps volcanic ash at these low-wind doldrum latitudes was not dispersed over these sites.

6 . With rare exceptions, chert-rich facies represent either a mixture of clay and silica, or a mixture of carbonate and silica. Significant chert is not observed within a calcareous claystone or within a marly limestone, suggesting that the triple combination of silica-claycarbonate either does not lithify or else loses one of its components during diagenesis.

Within these broad facies trends of the western Pacific are several global sedimentation phenomena and numerous site-dependent features. We will now examine the details of the sedimentation and diagenesis record at these sites, principally the Jurassic and earliest Cretaceous record at Sites 801 and 800 , and of the sedimentary processes that influenced the facies.

\section{LITHOSTRATIGRAPHY AND PETROLOGY OF DSDP-ODP SITES}

\section{Middle Jurassic}

\section{Upper Bathonian Interflow Sediments at Site 801}

Holes $801 \mathrm{~B}$ and $801 \mathrm{C}$ penetrated $125 \mathrm{~m}$ of basaltic flows (approximately 466 to $591 \mathrm{mbsf}$ ), the oldest oceanic crust ever recovered by deep-sea drilling. Interbedded within these flows and sills of olivine/ plagioclase-phyric basalt to aphyric dolerite are several horizons of altered pelagic sediment and volcaniclastics, and a Fe-rich silica deposit of hydrothermal origin.

Chert fragments from the topmost interflow sediments or directly overlying sediment (Cores 801B-39R and -37R) contain a radiolarian assemblage with co-occurrence of Tricolocapsa conexa and Guexella nudata, but lacking Stylocapsa tecta and Stylocapsa catenarum (Mat- suoka, 1991, and this volume). This combination is assigned to the middle part of the Tricolocapsa conexa radiolarian Zone in the Jurassic zonation of Japan (Matsuoka and Yao, 1986), implying a geologic age of middle-late Middle Jurassic. The middle Tricolocapsa conexa radiolarian Zone is correlated to the approximate boundary of Mediterranean-Atlantic radiolarian Zones A0 and A1 of Baumgartner (1984), to which Baumgartner (1987) assigns an age of latest Bathonian-earliest Callovian (Matsuoka, 1991, and this volume). However, Meyerhoff Hull and Pessagno (1991) correlate the Tricolocapsa conexa radiolarian Zone to their North American Zone 2, Subzone 2 gamma radiolarian assemblage, implying an age of upper Oxfordian, whereas revision of the European radiolarian zonation has lowered the corresponding geological age correlation to Bathonian (Jurassic-Cretaceous Working Group, in press; A. Matsuoka, pers. comm., 1991). Faced with the dilemma of divergent radiolarian zone correlations to geological age, the initial geological age assignments by Matsuoka (1991, and this volume) will be retained in this report. The deeper pillow-basalt horizons must be earliest Callovian-latest Bathonian or older.

The underlying basaltic crust was generated in two episodes: the initial formation of typical mid-ocean ridge tholeiitic basalts, and a later eruption or injection of off- or near-axis alkalic volcanics of oceanic-island-type chemistry (Floyd et al., 1991; Castillo and Floyd, this volume). The lower volcanic series yielded an argon-argon single-crystal radiometric age date of $167 \pm 4.5 \mathrm{Ma}$ (Pringle, this volume), which is consistent with a Bathonian-earliest Callovian age on the DNAG time scale. However, aphyric basalts from the upper volcanic episode yielded a mean radiometric age date of $157 \pm 0.5 \mathrm{Ma}$ (Floyd et al., 1991; Pringle, this volume), which corresponds to a geologic age of late Oxfordian and implies a minimum delay of approximately $5 \mathrm{~m}$.y. between the two volcanic episodes. The radiometric age dates derived from the volcanic series are not entirely consistent with the biostratigraphic ages. This conflict between age assignments may be caused by a combination of many factors, including miscalibration of the DNAG time scale by 5-10 m.y. for this time interval, miscalibration of the Japanese radiolarian zonation to geological stages, partial resetting of the radiometric age, and/or later intrusion of the upper fine-grained homogeneous volcanic series as sills into older sediments.

Separating these two volcanic formations is a silicified hydrothermal deposit consisting of $10 \mathrm{~m}$ (from driller's log; recovered thickness is $3 \mathrm{~m}$ ) of iron hydroxide (goethite) and quartz (Core 801C-4R). Intermittent pulses of volcanic activity recurring over a $10^{4} \mathrm{yr}$ or longer episode, with intervening deposition of pelagic or hydrothermal sediments, is a common feature of slow-spreading ridges and exposed ophiolites (e.g., Robertson, 1981; Macdonald, 1986; Karpoff et al., 1988; Karson and Rona, 1990; Vogt et al., 1990). Because the two volcanic episodes are distinctly separated in time and chemistry, we will independently summarize the pelagic sedimentation associated with each.

\section{Interflow Sediments of Earlier Volcanic Episode (Cores $801 C-12 R$ through $-5 R$ )}

Lithology. Metalliferous, radiolarian-bearing claystone to clayey radiolarite (estimated $40 \%$ radiolarians) is found in direct contact with basalt pillows in several cores (Cores 801C-9R, $-8 R,-6 R$, and $-5 R$ ), but nowhere exceeding $1 \%-2 \%$ of the core recovery. In some cases, a thin intervening layer of volcaniclastic-rich claystone separates the basalt and sediments. The contact zone on basalt is altered to greenish and brownish metalliferous claystone, which is interpreted as a smectite replacement or palagonization of volcanic glass. Calcite has replaced radiolarians and is present as micrite and patches of spar within the claystone. Some radiolarian molds have remnants of a prior chalcedony filling. There are rare unidentified recrystallized calcitic forms that are possibly fecal pellets or molds of foraminifers. The clay-rich matrix is highly enriched (up to $70 \%$ ) in Fe-oxyhydroxides, which occur as fine silt-sized globules and aggregates of "reddish brown 
Table 6. Microprobe analyses of radiolarite samples from Sites 801 and 800.

\begin{tabular}{|c|c|c|c|c|c|c|c|c|c|c|c|c|c|}
\hline \multirow[b]{2}{*}{ Lithology } & \multirow[b]{2}{*}{ Points } & \multicolumn{12}{|c|}{ Oxide (wt\% by stoichiometry) } \\
\hline & & $\mathrm{SiO}_{2}$ & $\mathrm{Al}_{2} \mathrm{O}_{3}$ & $\mathrm{Fe}_{2} \mathrm{O}_{3}$ & $\mathrm{MnO}_{2}$ & $\mathrm{~K}_{2} \mathrm{O}$ & $\mathrm{MgO}$ & $\mathrm{TiO}_{2}$ & $\mathrm{CaO}$ & $\mathrm{P}_{2} \mathrm{O}_{5}$ & $\mathrm{BaO}$ & Total & Residual \\
\hline \multicolumn{14}{|c|}{ Sample $801 \mathrm{C}-8 \mathrm{R}-1,30-31 \mathrm{~cm}$ (contort to basalt pillow); late Bathonian } \\
\hline Altered basalt & 6 & 54.68 & 7.22 & 17.35 & 0.04 & 8.41 & 5.10 & 0.10 & 0.23 & 0.08 & 0.07 & 93.27 & 6.73 \\
\hline Fe-rich "claystone" & 13 & 39.07 & 5.02 & 29.35 & 0.22 & 3.48 & 4.89 & 0.07 & 1.03 & 0.10 & 0.02 & 83.23 & 16.77 \\
\hline Calcite-rich metalliferous radiolarite & 78 & 29.19 & 3.65 & 18.40 & 0.24 & 3.11 & 3.47 & 0.05 & 16.09 & 0.08 & 0.03 & 74.30 & $23.14 *$ \\
\hline Bulk average & 100 & 33.41 & 4.19 & 20.57 & 0.23 & 3.49 & 3.81 & 0.06 & 12.78 & 0.08 & 0.03 & 78.65 & 21.35 \\
\hline \multicolumn{14}{|l|}{ Sample 801B-36R-CC, 1-4 cm; late Callovian } \\
\hline Radiolarian clusters & 10 & 92.94 & 0.41 & 0.13 & 0.01 & 0.08 & 0.04 & 0.02 & 0.05 & 0.01 & 0.06 & 93.75 & 6.25 \\
\hline Matrix & 27 & 49.51 & 8.09 & 7.50 & 0.10 & 2.84 & 1.84 & 0.18 & 0.46 & 0.05 & 0.03 & 70.58 & 29.42 \\
\hline Bulk average & 43 & 62.14 & 5.46 & 5.16 & 0.07 & 1.89 & 1.22 & 0.12 & 0.33 & 0.03 & 0.04 & 76.45 & $23.55^{*}$ \\
\hline \multicolumn{14}{|c|}{ Sample $801 \mathrm{~A}-33 \mathrm{R}-1,26-29 \mathrm{~cm}$ (clay $\rightarrow$ radiolarite): late Callovian } \\
\hline Claystone & 69 & 56.32 & 8.09 & 6.94 & 0.04 & 2.89 & 1.70 & 0.20 & 0.38 & 0.07 & 0.16 & 76.79 & 23.21 \\
\hline Transition to radiolarite $(2 \mathrm{~mm})$ & 32 & 64.18 & 5.22 & 5.92 & 0.03 & 1.87 & 1.14 & 0.16 & 0.21 & 0.06 & 0.06 & 78.83 & 21.17 \\
\hline Radiolarite & 73 & 64.62 & 3.83 & 5.05 & 0.03 & 1.29 & 0.87 & 0.15 & 0.25 & 0.06 & 0.10 & 76.26 & 23.74 \\
\hline Bulk average & 174 & 61.25 & 5.77 & 5.96 & 0.04 & 2.03 & 1.25 & 0.17 & 0.30 & 0.07 & 0.12 & 76.95 & $23.05 *$ \\
\hline \multicolumn{14}{|c|}{ Sample 801B-33R-1, 29-38 cm (several layers); late Callovian } \\
\hline Clay-rich layer & 13 & 57.79 & 6.83 & 6.62 & 0.05 & 2.35 & 1.53 & 0.11 & 0.35 & 0.04 & 0.03 & 75.71 & 24.29 \\
\hline Radiolarian claystone layer & 28 & 65.52 & 3.41 & 3.80 & 0.03 & 1.27 & 0.79 & 0.06 & 0.19 & 0.04 & 0.01 & 75.12 & 24.88 \\
\hline Fe-rich layer & 21 & 61.50 & 3.61 & 5.22 & 0.03 & 1.34 & 0.85 & 0.35 & 0.19 & 0.05 & 1.43 & 74.56 & 25.44 \\
\hline Silica-rich layer & 79 & 65.14 & 2.02 & 2.52 & 0.03 & 0.77 & 0.41 & 0.04 & 0.11 & 0.03 & 0.06 & 71.13 & 28.62 \\
\hline Clayey radiolarite layer & 53 & 61.25 & 3.12 & 3.87 & 0.04 & 1.14 & 0.66 & 0.06 & 0.16 & 0.04 & 0.05 & 70.39 & 29.61 \\
\hline $\mathrm{Fe}$-rich horizon & 5 & 52.63 & 3.73 & 15.53 & 0.08 & 1.26 & 0.92 & 0.14 & 0.27 & 0.24 & 0.01 & 74.80 & 25.20 \\
\hline Radiolarian-rich layer & 39 & 62.73 & 3.42 & 4.03 & 0.03 & 1.21 & 0.70 & 0.11 & 0.18 & 0.04 & 0.43 & 72.89 & 27.11 \\
\hline Bulk average & 238 & 62.94 & 3.10 & 3.95 & 0.03 & 1.13 & 0.67 & 0.10 & 0.17 & 0.04 & 0.23 & 72.35 & $27.56 *$ \\
\hline \multicolumn{14}{|c|}{ Sample 801B-27R-1, 19-21 cm; early Tithonian } \\
\hline Lower radiolarite & 64 & 70.26 & 3.82 & 2.50 & 0.33 & 1.09 & 0.81 & 0.08 & 0.25 & 0.03 & 0.27 & 79.46 & 20.54 \\
\hline Mn-poor horizon & 16 & 70.76 & 4.30 & 2.87 & 0.09 & 1.38 & 0.88 & 0.05 & 0.28 & 0.06 & 0.04 & 80.70 & 19.30 \\
\hline Upper radiolarite & 36 & 70.79 & 3.90 & 2.69 & 0.30 & 1.15 & 0.92 & 0.08 & 0.28 & 0.06 & 0.06 & 80.23 & 19.77 \\
\hline Bulk average & 116 & 70.49 & 3.91 & 2.61 & 0.29 & 1.15 & 0.86 & 0.08 & 0.27 & 0.04 & 0.17 & 79.87 & $20.13^{*}$ \\
\hline \multicolumn{14}{|l|}{ Sample $800 \mathrm{~A}-52 \mathrm{R}-3,26-29 \mathrm{~cm}$; Valanginian } \\
\hline "Mn-rich" radiolarite & 43 & 74.39 & 4.47 & 2.79 & 0.44 & 1.57 & 0.99 & 0.09 & 0.72 & 0.37 & 0.03 & 85.86 & 14.14 \\
\hline "Mn-poor" claystone & 38 & 72.88 & 4.99 & 3.57 & 0.08 & 1.78 & 1.21 & 0.11 & 0.31 & 0.09 & 0.03 & 85.05 & 14.95 \\
\hline Claystone layer & 12 & 69.75 & 5.74 & 3.74 & 0.06 & 2.06 & 1.47 & 0.10 & 0.32 & 0.11 & 0.03 & 83.38 & 16.62 \\
\hline Average of clay + Mn-rich & 55 & 72.07 & 5.11 & 3.27 & 0.25 & 1.81 & 1.23 & 0.09 & 0.52 & 0.24 & 0.03 & 84.62 & 15.38 \\
\hline Bulk average & 81 & 73.70 & 4.71 & 3.15 & 0.27 & 1.66 & 1.09 & 0.10 & 0.53 & 0.24 & 0.03 & 85.49 & 14.51 \\
\hline
\end{tabular}

Notes: For each set of analyses, a suite of transects was made across polished thin sections using a 20- $\mu \mathrm{m}$ beam-spot size. Weight percentages of oxides are converted to proportions of biogenic silica, clay, and metal oxide by assuming that the clay is a mixed-layer Fe-rich smectite incorporating half of the Fe ions and all $\mathrm{Al}$, $\mathrm{K}$, and $\mathrm{Mg}$. Layers of different lithologies in the various samples are tabulated separately, and the variations are discussed in the text. Measurements suites marked by an asterisk (*) are considered to represent the bulk composition of the lithologic subunit.

semi-opaque objects," or "RSOs," similar to those described from pelagic clay (Shipboard Scientific Party, 1976). The initial sediment was probably a metalliferous clayey radiolarite, similar to the overlying Callovian sediment. Early partial-mobilization of silica was followed by pervasive calcification and silica-replacement, which probably was induced by release of calcium during weathering of the basalt.

Chemistry. Microprobe transects (100 measurements) across a transition from basalt to calcite-rich metalliferous clayey radiolarite from Sample 801C-8R-1, 30-31 cm, indicated that Si-Al-Ti-Mg remained in the same relative proportions regardless of lithology (Table 6). $\mathrm{Fe}_{2} \mathrm{O}_{3}$ and $\mathrm{CaO}$ are enriched in the radiolarian claystone to approximately $20 \%$. The calcified-radiolarian claystone has a relative ratio of Fe:Al:Mn oxides equal to 100:20:1, which is comparable to metalliferous claystone ("ochres") associated with ophiolite deposits; for example, metalliferous sediments associated with the Oman ophiolite have a general Fe-Al-Mn oxide ratio of 100:30:5 (Karpoff et al., 1988). Mg is enriched compared to overlying claystones, a trend consistent with observed concurrent $\mathrm{Fe}$ and $\mathrm{Mn}$ enrichment in pelagic clays and metalliferous sediments (Yamamoto, 1988). $\mathrm{Al}_{2} \mathrm{O}_{3}$ is low (less than 4\%) in the "claystone," suggesting that most of the clays represent $\mathrm{Fe}$-smectites formed by diagenesis.

The abundance of Fe and very low concentration of Mn (the $\mathrm{Fe} / \mathrm{Mn}$ ratio is approximately 70 ) is consistent with the chemistry of certain sediments deposited at other spreading centers (Bonatti, 1975). In general, proximal deposits to active ridges are Fe-enriched, whereas distal deposits are Mn-enriched (Karpoff et al., 1988). This Fe-enrichment and Mn-depletion continues through the overlying Callovian claystones.

\section{Interflow Sediments of Later Volcanic Episode (Cores 801C-3R through 801B-37R)}

Lithology. Pelagic sediment was recovered mainly in three interflow or intersill horizons within the late-stage volcanic episode at Site 801, in the middle of Cores $801 \mathrm{~B}-43 \mathrm{R}$ and $-44 \mathrm{R}$ and comprising the recovery of Core 801B-39R. Several pieces of chert were also noted at the tops of some cores, but they are probably cavings from the overlying chert-rich breccia of Core 801B-37R. Each of the three sediment horizons displays 


\begin{tabular}{|c|c|c|c|c|c|c|c|}
\hline \multirow[b]{2}{*}{ Lithology } & \multicolumn{3}{|c|}{ Approximate composition } & \multicolumn{4}{|c|}{ Elemental ratios } \\
\hline & $\begin{array}{c}\text { Fe- } \\
\text { smectite }\end{array}$ & $\mathrm{SiO}_{2}$ & $\begin{array}{l}\mathrm{Fe}-\mathrm{Mn} \\
\text { oxides }\end{array}$ & $\begin{array}{c}\mathrm{Al} /(\mathrm{Al}+\mathrm{Fe}+\mathrm{Mn}) \\
(\mathrm{wt} \%)\end{array}$ & $\begin{array}{l}\mathrm{Ti} / \mathrm{Al} \\
(\mathrm{wt} \%)\end{array}$ & $\begin{array}{l}\mathrm{Fe} / \mathrm{Mn} \\
(\mathrm{wt} \%)\end{array}$ & $\begin{array}{c}\mathrm{Al} / \mathrm{K} \\
\text { (atomic) }\end{array}$ \\
\hline \multicolumn{8}{|c|}{ Sample 801C-8R-1, 30-31 cm (contort to basalt pillow); late Bathonian } \\
\hline Altered basalt & 44.0 & 35.65 & 9.34 & .24 & .016 & 373 & 0.79 \\
\hline Fe-rich "claystone" & 62.9 & 13.41 & 17.89 & .11 & .016 & 120 & 1.33 \\
\hline Calcite-rich metalliferous radiolarite & 45.8 & 14.96 & 12.70 & .13 & .016 & 70 & 1.08 \\
\hline Bulk average & 48.7 & 16.63 & 13.37 & .13 & .017 & 81 & 1.10 \\
\hline \multicolumn{8}{|c|}{ Sample 801B-36R-CC, 1-4 cm; late Callovian } \\
\hline Radiolarian clusters & 1.2 & 98.52 & 0.08 & .68 & .058 & 10 & 4.53 \\
\hline Matrix & 41.9 & 48.85 & 5.45 & 45 & .025 & 68 & 2.62 \\
\hline Bulk average & 26.3 & 67.92 & 3.46 & .44 & .024 & 69 & 2.65 \\
\hline \multicolumn{8}{|c|}{ Sample 801A-33R-1, 26-29 cm (clay $\rightarrow$ radiolarite); late Callovian } \\
\hline Claystone & 37.5 & 54.33 & 4.58 & .47 & .028 & 141 & 2.57 \\
\hline Transition to radiolarite ( $2 \mathrm{~mm}$ ) & 26.1 & 68.10 & 3.79 & .40 & .035 & 165 & 2.56 \\
\hline Radiolarite & 21.1 & 73.92 & 3.35 & .36 & .045 & 157 & 2.73 \\
\hline Bulk average & 28.5 & 65.07 & 3.92 & .42 & .034 & 150 & 2.61 \\
\hline \multicolumn{8}{|c|}{ Sample 801B-33R-1, 29-38 cm (several layers); late Callovian } \\
\hline Clay-rich layer & 33.5 & 59.29 & 4.44 & .44 & .019 & 112 & 2.68 \\
\hline Radiolarian claystone layer & 17.7 & 78.16 & 2.56 & .40 & .021 & 136 & 2.47 \\
\hline Fe-rich layer & 21.1 & 71.60 & 3.55 & .34 & .109 & 141 & 2.49 \\
\hline Silica-rich layer & 11.6 & 85.62 & 1.81 & .38 & .025 & 86 & 2.43 \\
\hline Clayey radiolarite layer & 18.1 & 77.75 & 2.80 & .38 & .023 & 89 & 2.51 \\
\hline Fe-rich horizon & 40.4 & 48.97 & 10.48 & .15 & .042 & 176 & 2.72 \\
\hline Radiolarian-rich layer & 18.8 & 76.47 & 2.81 & .39 & .038 & 109 & 2.61 \\
\hline Bulk average & 17.7 & 77.92 & 2.78 & .37 & .035 & 107 & 2.52 \\
\hline \multicolumn{8}{|c|}{ Sample 801B-27R-1, 19-21 cm; early Tithonian } \\
\hline Lower radiolarite & 15.8 & 80.47 & 1.99 & .50 & .025 & 7 & 3.22 \\
\hline Mn-poor horizon & 17.5 & 78.83 & 1.88 & .52 & .013 & 30 & 2.87 \\
\hline Upper radiolarite & 16.2 & 80.07 & 2.05 & .49 & .023 & 8 & 3.14 \\
\hline Bulk average & 16.1 & 80.12 & 2.00 & .50 & .023 & 8 & 3.13 \\
\hline \multicolumn{8}{|l|}{ Sample $800 \mathrm{~A}-52 \mathrm{R}-3,26-29 \mathrm{~cm}$; Valanginian } \\
\hline "Mn-rich" radiolarite & 16.8 & 78.16 & 2.14 & .51 & .022 & 5.7 & 2.63 \\
\hline "Mn-poor" claystone & 19.7 & 75.73 & 2.19 & .51 & .026 & 39.4 & 2.59 \\
\hline Claystone layer & 22.5 & 72.29 & 2.31 & .53 & .020 & 56.6 & 2.57 \\
\hline Average of clay $+\mathrm{Mn}$-rich & 19.7 & 75.27 & 2.22 & .52 & .021 & 11.8 & 2.59 \\
\hline Bulk average & 18.2 & 77.04 & 2.16 & .51 & .024 & 10.3 & 2.61 \\
\hline
\end{tabular}

a different character, with interpretation of the original sediment facies complicated by later diagenesis, especially calcification.

Fe-rich radiolarian claystone alternating with clayey radiolarite dominates the pelagic sediments within the middle of Core $801 \mathrm{~B}$ 44R. This interval, of at least $55 \mathrm{~cm}$ thickness, also contains at least two interbeds of silicified tuffs or pyroclastic flows. Radiolarians are generally partially replaced or filled with calcite, with greater calcification where the original sediment had a higher radiolarian content. Indeed, poorly preserved and calcite-replaced fragments of radiolarian tests within recrystallized limestone horizons, coupled with the absence of identifiable calcareous microfossils, suggests that calcification and recrystallization can completely replace a former radiolarian "sand." The tuffaceous layers contain lapilli and may have partial calcification of a former silica-rich matrix. Radiolarian claystone adjacent to the tuff layers is partially silicified in places. The iron oxides are mainly present as dispersed dark fine-grained particles within the claystone, in contrast to the reddish semi-opaque "RSO" aggregates characteristic of the sediments within the underlying volcanic episode or overlying Callovian.

Recrystallized limestone is present within the middle of Core 801B-43R as a bed overlying basalt pillows and as interpillow fillings. The original sediment texture and most microfossils have been totally obscured, although some unidentifiable bioclasts are present within millimeter-sized micritic granules. Rare poorly preserved nannofossils of Watznaueria manivitae were found within millimeter-sized calcareous claystone fragments within one of these interpillow fillings. The chance preservation of nannofossils and possible "recrystallized foraminifers" in this interval (Shipboard Scientific Party, 1990c) suggest that there was an original calcareous component within the otherwise ubiquitous radiolarian claystone. The calcification in this interval and elsewhere within the basaltic basement is probably associated with release of calcium during seawater-influenced alteration of submarine basalts.

Silicified metalliferous clayey radiolarite comprises the $30-\mathrm{cm}$ recovery of Core 801B-39R (Fig. 4A). Pervasive mottling and the absence of laminations indicate bioturbation. Radiolarians are generally silica-filled and packed together within the equant burrows, and are flattened and less abundant within the clay- and iron-rich matrix. Mottling is locally enhanced by diagenetic processes. This mottled radiolarite texture is similar to the fine-mottled "woody" textures occurring within Callovian to Lower Cretaceous radiolarites, which are also considered to be a product of bioturbated homogenization and diagenetic silica redistribution.

In general, sedimentation at the late Bathonian ridge crest consisted of metalliferous clayey radiolarite and radiolarian claystone. At 

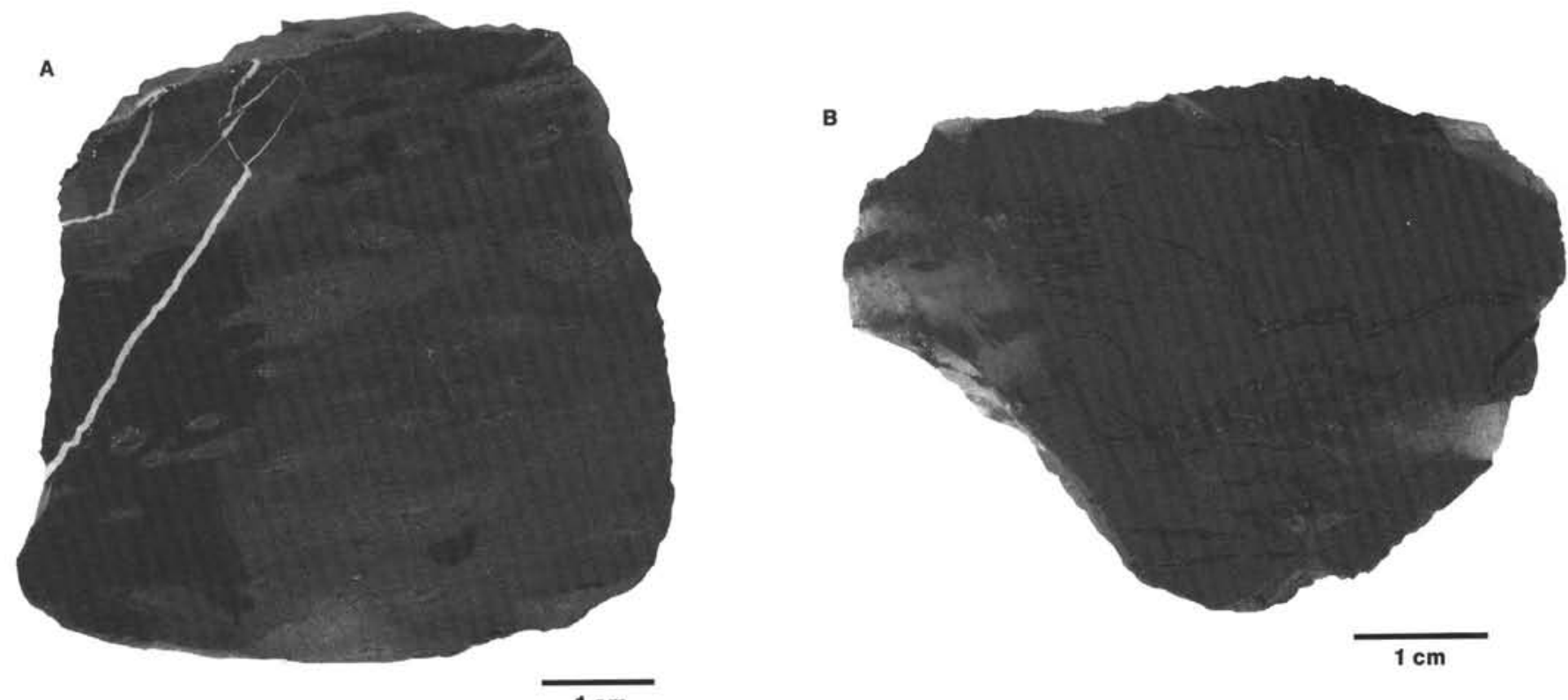

$1 \mathrm{~cm}$

Figure 4. Latest Bathonian or earliest Callovian facies, Site 801. A. Metalliferous clayey radiolarite, now silicified, from within the upper alkalic-volcanic basement complex. The pervasive mottling and lack of laminations is probably due to homogenization by bioturbation. Radiolarians are generally silica-filled and packed together within the rounded mottles, and are less abundant within the clay- and iron-rich inter-mottle regions. Some of this mottled texture may be due to localized silica dissolution and precipitation within an initially semi-homogeneous clayey radiolarite. Interval 129-801B-39R-1, 27-32 cm. B. Lowermost Callovian silicified claystone overlying the alkalic-volcanic basement complex. Reddish-brown "crackle-breccia" chert developed from a former iron-rich claystone through fracturing and silicification. The fractures within the silicified claystone are filled with drusy quartz. The chertified claystone fragments contain only rare radiolarians. Interval 129-801B-37-1,11-16 cm.

ridge-crest depths near the equator, calcareous microfossils were rare or not preserved within the sediment.

\section{Callovian at Site 801-Interbedded Radiolarite and Claystone}

From the top of the volcanic basement through the Lower Cretaceous, core recovery was minimal. Therefore, Formation MicroScanner resistivity imagery and geochemical logs (Molinie and Ogg, this volume) provide a valuable supplement for interpreting the sedimentary record from the Callovian through Valanginian sedimentary formations (Fig. 2). The Formation MicroScanner indicates that the top of the basaltic basement is at approximately $467 \mathrm{mbsf}$, or approximately at the base of Core 801B-37R. The immediately overlying chert in Core 801B-37R (Fig. 4B) is assigned an age of latest Bathonian to earliest Callovian, according to correlations of its radiolarian assemblage (Matsuoka, 1991, and this volume), as explained previously. The next $22 \mathrm{~m}$ consist of a series of slumped clay, radiolarite and chert deposits, comprising the majority of Cores 801B-37R through -33R. Nonredeposited Callovian strata comprise only $5.4 \mathrm{~m}$ (uppermost Cores $801 \mathrm{~B}-33 \mathrm{R}$ and $-32 \mathrm{R}$ ), and are terminated by a Callovian/Oxfordian hiatus at $439.4 \mathrm{mbsf}$.

A radiolarian assemblage from the middle of the slump deposits (Sample 801B-35R-3, 24-26 cm) contains Stylocapsa tecta, which was absent in Core 801B-37R at the base of the slump deposits, and Tricolocapsa conexa, but lacks Stylocapsa(?) spiralis, and therefore is assigned to the upper part of the Tricolocapsa conexa radiolarian Zone (Matsuoka, 1991, and this volume). Through correlation to the upper part of Tethyan radiolarian Zone A1 of Baumgartner (1984, 1987), the corresponding geologic age assignment is early to middle Callovian (Matsuoka, 1991, and this volume). Stylocapsa(?) spiralis is found throughout Cores 801B-33R and upper -34R, indicating the presence of the lower portion of the Stylocapsa(?) spiralis radiolarian Zone. Correlation of this zone to Tethyan radiolarian Zone A2 of Baumgartner implies an age assignment of late Callovian (Shipboard Scientific Party, 1990c). The absence of
Stichocapsa naradaniensis indicates that only the lower part of the $S$.(?) spiralis radiolarian Zone is present (Matsuoka and Yao, 1986). The overlying brown radiolarites of Core 801B-32R contain radiolarians diagnostic of the Cinguloturris carpatica radiolarian Zone of middle and late Oxfordian. Therefore, a hiatus at the top of this unit encompasses the upper portion of the Stylocapsa(?) spiralis radiolarian Zone and lower part of the Cinguloturris carpatica radiolarian Zone, implying that the latest Callovian and much of the early Oxfordian is not represented (Matsuoka, this volume).

These correlations of radiolarian assemblages imply that the slumped lower interval incorporates strata of latest Bathonian through middle Callovian age, and that the undisturbed upper interval comprises only sediments of late Callovian age. The mean sedimentation rate for this $27-\mathrm{m}$ Callovian interval is approximately $4-5 \mathrm{~m} / \mathrm{m}$.y. However, accumulation of slumped material and debris flows has probably thickened the original stratigraphic thickness of the deposits.

During this Callovian interval, the seafloor subsided from $2700 \mathrm{~m}$ to a depth of approximately $3300 \mathrm{~m}$ and drifted southward to approximately $250-300 \mathrm{~km}$ from the spreading ridge. The average paleolatitude is estimated as approximately $8^{\circ} \mathrm{S}$.

\section{Uppermost Bathonian through Middle Callovian (467-445 mbsf; Cores $801 B-37 R$ to $-33 R-1,95 \mathrm{~cm}$ )-Slump Deposits}

Sedimentary Structures. Lower Callovian strata appear on the Formation MicroScanner imagery as lacking coherent internal bedding, displaying irregular and commonly steep contacts with random orientations between blocks of different lithologies, and encompassing clasts of higher-resistance material (chert or porcellanite) within a low-resistance clay-rich matrix (Molinie and Ogg, this volume). The sediments recovered from these cores consist of red claystone interbedded with randomly oriented, cohesive blocks, $1-20 \mathrm{~cm}$ thick, of clayey radiolarite to chert. These observations indicate that the lower 


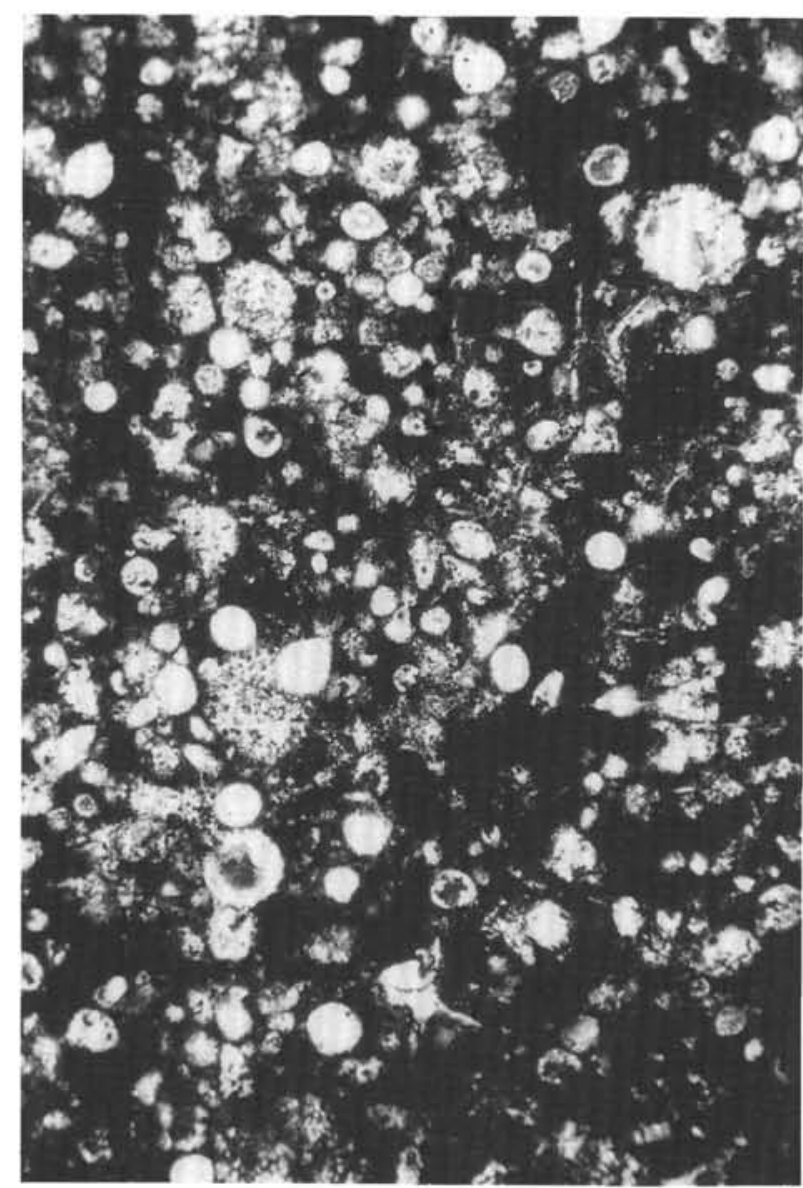

Figure 5. Early Callovian facies, Site 801. Photomicrogrâph of uppermost Bathonian to lowermost Callovian metalliferous clayey radiolarite overlying the alkalic-volcanic basement complex. Silica-filled radiolarian molds are packed within a very dark claystone matrix having a relatively high abundance of Fe-oxide particles and reddish semi-opaque "RSO" aggregates of iron oxyhydroxides. Radiolarian spines and some ornamentation is preserved. Photomicrograph in plane light, 10 ö magnification (width of view is $0.5 \mathrm{~mm}$; orientation unknown). Interval 129-801B-36R-CC, $2-4 \mathrm{~cm}$ (entire recovery of core).

Callovian sediments consist of slump deposits of disrupted radiolarite within a clay-rich matrix. The lowest few meters may include debris flows. Fragments of a conglomerate, consisting of poorly sorted, fine-pebble-size, rounded clasts of radiolarite to radiolarian claystone within a matrix of radiolarian-bearing porcellanite, were recovered from Core $801 \mathrm{~B}-34 \mathrm{R}$, possibly from an analogous debris flow.

Basal Silicification. Downhole logs of the lowest $5 \mathrm{~m}$ of this interval display an upward decrease in average resistivity, indicating an upward decrease in silicification of the matrix. Recovered sediments from this interval (Core 801B-37R, and a piece at the top of Core $38 \mathrm{R}$ which was probably displaced downhole) consist of reddish-brown "crackle-breccia" chert, which developed from a former iron-rich claystone through fracturing and silicification (Fig. 4B). The fractures within the silicified claystone are filled with drusy quartz. Behl and Smith (this volume) suggest that this crackle-breccia was formed when a soft sediment underwent rapid dewatering or fluid injection associated with the intrusion of basalt sills, followed by quartz cementation of the desiccation fractures. Alternatively, the brecciation may be dilational structugies adjacent to a décollement contact to the overlying submarine slump deposit (e.g., Winterer et al., 1991). The chertified claystone fragments contain only rare radiolarians, therefore the source of the silica is either external, perhaps from palagonized glass, or from dissolved radiolarians.
Origin of Slump Deformation. Above these basal chert-rich sediments, the remainder of the slump blocks appear to consist of alternations of claystone and clayey radiolarite without significant chertification (Fig. 5) - a facies also characteristic of the undisturbed upper Callovian. The few radiolarian-dated samples display the expected stratigraphic order of zones, indicating that the slump deposits did not mix uppermost Bathonian, lower Callovian, and middle Callovian strata. From the available evidence, it is not possible to determine whether this slumped interval represents a large olistrostrome or rotated block with internal deformation, or a series of individual slump and debris-flow deposits. Post-volcanic block rotations of oceanic crust are commonly observed (e.g., Carbotte and Macdonald, 1990; White et al., 1990), and overlying chalk deposits have been observed with dips from $10^{\circ}$ to more than $40^{\circ}$, implying that block-tilting may occur significantly later than emplacement of the uppermost lavas (Karson and Rona, 1990). Slumps of semi-brittle strata and associated dilational brecciation and neptunian dykes are common during lowangle tilting of submerged half-grabens (Winterer et al., 1991). The sharp contrast at Site 801 between the $20^{\circ}$-dipping upper Callovian and the overlying $10^{\circ}$-dipping Oxfordian implies that a major portion of the total rotation (tectonic tilting of basement and/or block rotation above a décollement surface) was synchronous with the CallovianOxfordian boundary.

\section{Upper Callovian (Cores $801 B-33 R-1,95 \mathrm{~cm}$, to $-32 R$ ) - Interbedded Red Radiolarite and Claystone}

Sedimentary Structures. The undisturbed $5.4 \mathrm{~m}$ of upper Callovian strata consists of thinly interbedded red radiolarite and claystone (Fig. 6A). Bands of unsilicified granular radiolarite, $1-2 \mathrm{~cm}$ thick, are semi-evenly spaced at 3-4-cm intervals. Contacts between the radiolarite and claystone layers are sharply defined in hand samples and consist of narrow transitions in thin section (Fig. 6B). The radiolarite horizons are vaguely laminated to bioturbated, with some intervals displaying anastomosing flaser-type structures; partial silicification occurs in rare lenses. The claystone interbeds are darker red and display moderate bioturbation. Bioturbation mixing occurred on a small scale only, as shown by the preservation of the thin and consistently parallel beds of clay and radiolarite. The frequency of radiolarite deposits is $6,000-20,000 \mathrm{yr}$, based on the $2-5-\mathrm{m} / \mathrm{m}$.y. estimate of accumulation rate.

Microfacies. Thin-section observations and microprobe transects across several claystone-radiolarite-claystone transitions from the Callovian alternations yield an interesting picture.

Claystone layers have $2 \%-20 \%$ radiolarians, dominated by uncompacted forms filled by microcrystalline quartz or chalcedony (Fig. 6C). The matrix contains about $15 \%-30 \%$ clay-sized "RSO" iron oxyhydroxides, $5 \%-10 \%$ fine-silt-sized mica, up to $5 \%$ silt-sized quartz, and rare fish-bone fragments.

Radiolarite layers consist of packed radiolarians (40\%-60\%), of which only about $10 \%$ have replacement or filling by microcrystalline quartz or chalcedony, the rest consist of compression-deformed relict tests and "ghosts" of former radiolarians, some of which are partially filled with silica (Fig. 6D). Within a radiolarite layer are horizons with only $20 \%$ radiolarians and rare lenticular pockets of radiolarian claystone. In general, the proportion of ghosts increases with greater abundance of total radiolarians. In fact, the observed changes in abundance of radiolarians within these radiolarite layers consist mainly of changes in the abundance of radiolarian ghosts; the population of silica-filled radiolarians remains much more constant. The silica-filled radiolarians retain more of the original shape, and, in many cases, have spines. No size-sorting or grading of radiolarians is apparent, and radiolarian abundances vary irregularly within the radiolarite layer. The matrix of the radiolarites consists of metalliferous clay, rich in reddish clay-sized "RSO" particles of iron oxyhydroxide and black silt-sized Fe-oxide particles (together comprising 
A

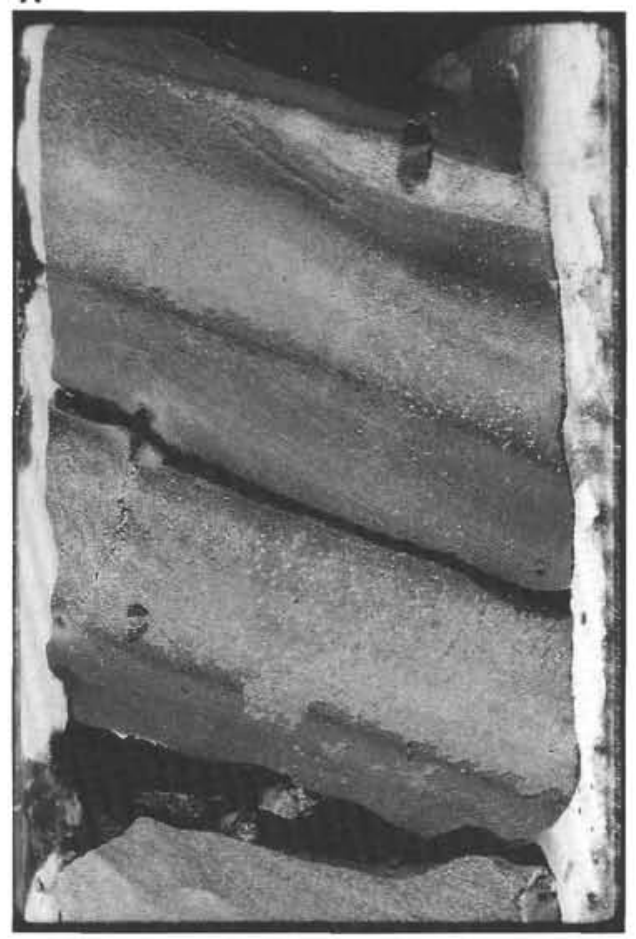

C

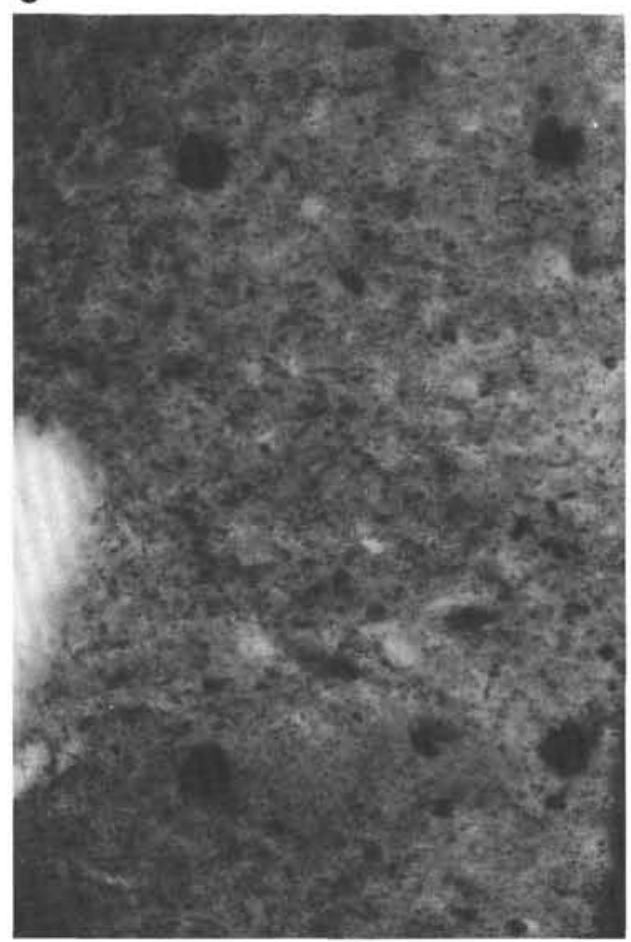

B

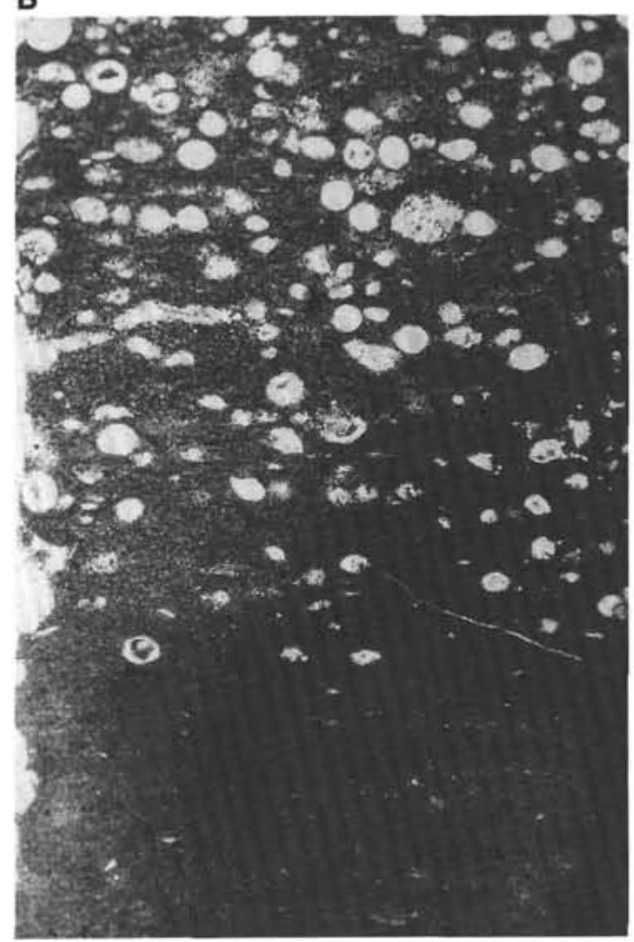

D

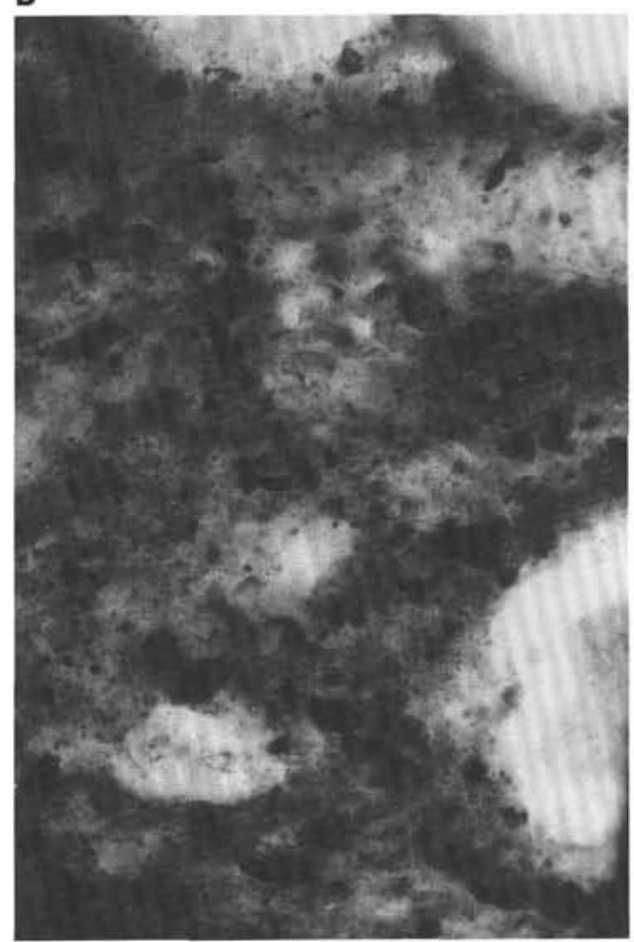

Figure 6. Late Callovian facies, Site 801, Core 33R. A. Upper Callovian red-colored radiolarite with alternations of clay-rich and radiolarian-rich layers. Strata dip at $15^{\circ}$ to $20^{\circ}$. These dipping beds may represent either tectonic tilting or a rotation above a décollement surface prior to the deposition of the overlying shallow-dipping Oxfordian strata. This succession was used for thin-section and microprobe transects of cycles (Figures 6B and 6C). Core is approximately actual size (width $=5.5 \mathrm{~cm}$ ). Interval 129-801B-33R-1, 20-30 cm. B. Photomicrograph of transition upward from claystone to radiolarite. Silica-filled radiolarians gradually increase in abundance upward over a 2-mm zone. This transition was analyzed by a series of microprobe transects (Table 6). Magnifications of each layer are Figures $6 \mathrm{C}$ and $6 \mathrm{D}$. Photomicrograph in plane light, $4 \times$ magnification (width of view is $2.0 \mathrm{~mm}$ ). Interval 129-801B-33R-1, 28-29 cm. C. Photomicrograph of claystone layer with dispersed particles and aggregates of reddish semi-opaque "RSO" iron oxyhydroxide. A silica-filled radiolarian mold is on the left. Black dots are burn spots from $20-\mu \mathrm{m}$ microprobe beam. Photomicrograph in plane light, $40 \times$ magnification (width of view is $0.20 \mathrm{~mm}$ ). Interval 129-801B-33R-1, $29 \mathrm{~cm}$. D. Photomicrograph of radiolarite layer with silica-filled and chalcedony-filled radiolarian molds in a metalliferous siliceous matrix. Matrix has numerous aggregates of reddish semi-opaque "RSO" iron oxyhydroxide particles. Photomicrograph in plane light, 40× magnification (width of view is $0.20 \mathrm{~mm}$ ). Interval $129-801 \mathrm{~B}-33 \mathrm{R}-1,28 \mathrm{~cm}$. 


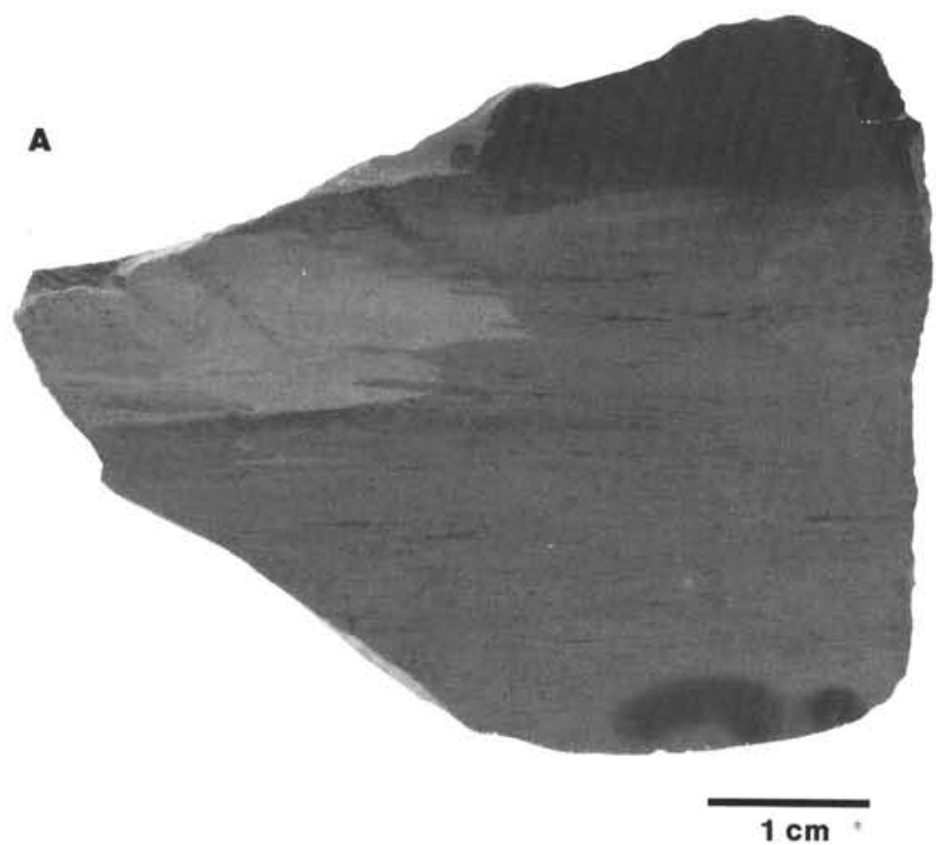

B

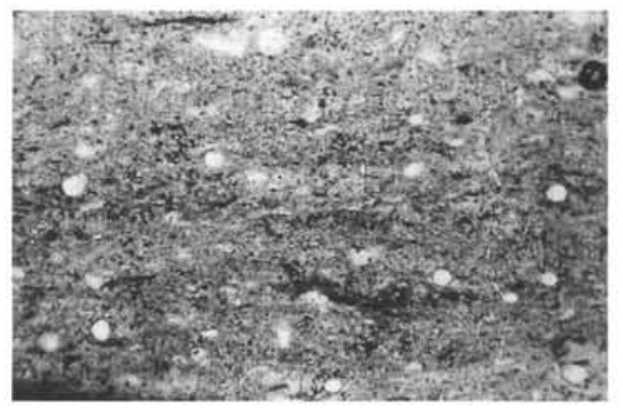

Figure 7. Late Jurassic facies, Site 801. A. Clayey radiolarite displays the characteristic brown "woody" texture of discontinuous wispy streaks of FeMn-oxide concentrations and of elongate microflaser-like variations in clay concentration. A reddish mottle caused by reduction of Mn-oxide is at the left side, a dark zone of silicification is at the top. This core has a middle Tithonian age. Interval 129-801 B-24R-1, 17-20 cm. B. Photomicrograph of characteristic "woody" texture of Upper Jurassic clayey radiolarites. Silica-filled radiolarian molds are distributed within a clay-rich matrix containing wispy streaks and small aggregates of FeMn-oxide concentrations. This core has a middle Tithonian age. Photomicrograph in plane light, $4 \times$ magnification (width of view is 2.5 mm). Interval 129-801B-25R-1, 56-55 cm.

up to $50 \%$ of the matrix), and containing fine-silt-sized mica (up to 20\%) (Fig. 6D).

Transitions from claystone upward to radiolarite span only 1$2 \mathrm{~mm}$, but the contacts are not sharp, which argues against radiolarian turbidites (Fig. 6B). Radiolarians, especially the partially-silicified forms, rapidly increase upward in abundance in the lower portion of the radiolarite layer. The claystone immediately below the radiolarite layer may have fewer radiolarians than in the underlying main claystone layer; a phenomenon possibly caused by enhanced silica dissolution from this adjacent claystone. Transitions from radiolarite upward to claystone are similar in appearance, but display a more gradual reduction in radiolarian abundance over a 3- to 4-mm zone.

Chemistry. Multiple microprobe transects (a total of 480 measurements with a $20-\mu \mathrm{m}$ beam size) were run on two sets of claystoneradiolarite layers (Samples 801B-33R-1, 26-29 cm, and 33R-1, $29-38 \mathrm{~cm}$; Figs. 6A and 6B). Claystone layers average $57 \%$ silica, $6.8 \% \mathrm{Fe}_{2} \mathrm{O}_{3}, 0.05 \% \mathrm{MnO}_{2}, 7.5 \% \mathrm{Al}_{2} \mathrm{O}_{3}, 2.5 \% \mathrm{~K}_{2} \mathrm{O}$, and $1.6 \% \mathrm{MgO}$, with about $24 \%$ loss-on-ignition (Table 6). The loss-on-ignition is probably a composite of porosity, water, and volatiles. Adjacent radiolarite layers have a similar $24 \%-25 \%$ loss-on-ignition; therefore, the elemental abundances can be compared directly to the claystone. The typical adjacent radiolarite is composed of $65 \%$ silica, $4.5 \% \mathrm{Fe}_{2} \mathrm{O}_{3}, 0.03 \% \mathrm{MnO}_{2}, 3.6 \% \mathrm{Al}_{2} \mathrm{O}_{3}, 1.3 \% \mathrm{~K}_{2} \mathrm{O}$, and $0.8 \% \mathrm{MgO}$. In addition to the silica-enrichment in the radiolarite, there is also an enrichment in Fe relative to clay $(\mathrm{Al}, \mathrm{K})$; the ratio of $\mathrm{Al} /(\mathrm{Al}+\mathrm{Fe}+\mathrm{Mn})$ drops from an average of 0.46 in the claystone to 0.38 in the adjacent radiolarite. $\mathrm{Fe}$ increases about $50 \%$ relative to $\mathrm{Al}$ in the radiolarite, as compared to the adjacent claystone. Within the radiolarite layer, higher $\mathrm{Al} / \mathrm{Fe}$ ratios are associated with increased clay content, and the inter-radiolarian matrix displays an increased abundance of clay- to silt-sized iron-oxide particles and small concretions (some spot analyses indicate up to $30 \% \mathrm{Fe}_{2} \mathrm{O}_{3}$ ). Mn is extremely low (Fe/Mn ratio is about 100 to 150 ) and is less variable in concentration than $\mathrm{Fe}$. $\mathrm{Ti}$ is slightly increased in abundance relative to $\mathrm{Al}$ in the radiolarite (typically $\mathrm{Ti} / \mathrm{Al}$ of 0.03 ) compared to adjacent claystone ( $\mathrm{Ti} / \mathrm{Al}$ of 0.023 ), and appears to have greatest abundance in Fe-rich horizons. It is possible that some Ti may be from devitrified volcanic glass. The ratio of $\mathrm{Al} / \mathrm{K}$ remains at $2.5-2.7$, independent of lithology.

We interpret these thin-section observations and geochemical data as indicating a two-stage mobilization of silica and Fe. In the first stage, a proportion of the radiolarians in the claystone and in the radiolarite were filled with silica (microcrystalline quartz or chalcedony); these radiolarians were resistant to later compaction and redistribution of silica. Silicification of radiolarite apparently substantially reduced permeability, locking in $\mathrm{Fe}$-oxides and preventing later free interaction with interstitial waters and reduction/dissolution of oxides (Behl and Smith, this volume). Some Fe may have migrated from adjacent claystone layers where iron hydroxides underwent partial reduction and dissolution.

\section{LATE JURASSIC}

The Pacific drilling record of the Upper Jurassic consists mainly of Site 801 and Site 307. Both sites indicate that sedimentation through the Upper Jurassic consisted only of clay-rich radiolarite and chert. The radiolarites are enriched in FeMn, especially near the ridge crest. No significant carbonate was preserved, even at depths less than $3 \mathrm{~km}$ in these tropical latitudes.

\section{Oxfordian through Tithonian Radiolarites at Site 801}

From the Oxfordian through middle Tithonian (M33-M21), the Hawaiian and Japanese magnetic patterns indicate fairly stable rates and directions of seafloor spreading (Handschumacher et al., 1988). The paleolatitude curve (Fig. 3) indicates that the Pacific Plate was moving northward during this period. Site 801 would have drifted progressively northward from $8^{\circ} \mathrm{S}$ to the paleoequator, and deepened from 3500 to $3900 \mathrm{~m}$ (Table 5).

A total of $43 \mathrm{~m}$ of brown clayey radiolarite, comprising Lithologic Subunit IVB, was deposited during this period. Formation Micro-Scan- 
Table 7. Mass accumulation rates of iron, manganese, aluminum, biogenic silica, and carbonate.

\begin{tabular}{|c|c|c|c|c|c|c|c|c|}
\hline & Age & Paleolatitude & $\begin{array}{l}\text { Sedimentation } \\
\text { rate (m/m.y.) }\end{array}$ & $\begin{array}{l}\text { Bulk density } \\
\left(\mathrm{g} / \mathrm{cm}^{3}\right)\end{array}$ & $\begin{array}{c}\mathrm{Fe}_{2} \mathrm{O}_{3} \\
(\%)\end{array}$ & $\begin{array}{c}\mathrm{Fe} \\
\left(\mathrm{g} / \mathrm{cm}^{2} / \mathrm{m} . \mathrm{y}\right)\end{array}$ & $\underset{(\%)}{\mathrm{MnO}_{2}}$ & $\begin{array}{c}\mathrm{Mn} \\
\left(\mathrm{g} / \mathrm{cm}^{2} / \mathrm{m} . \mathrm{y} .\right)\end{array}$ \\
\hline \multicolumn{9}{|l|}{$\begin{array}{l}\text { Sites } 800 \text { and } 801^{\mathrm{a}} \\
\text { Sample }\end{array}$} \\
\hline $801 \mathrm{C}-8 \mathrm{R}-1,30-31 \mathrm{~cm}$ & late Bathonian & $7^{\circ} \mathrm{S}$ & 2.0 & 2.4 & 18.4 & 62 & 0.24 & 0.9 \\
\hline 801B-36R-CC, $2-4 \mathrm{~cm}$ & early Callovian & $6^{\circ} \mathrm{S}$ & 2.0 & 2.0 & 5.2 & 14 & 0.07 & 0.2 \\
\hline $801 \mathrm{~B}-33 \mathrm{R}-1,26-29 \mathrm{~cm}$ & late Callovian & $5^{\circ} \mathrm{S}$ & 2.0 & 2.0 & 5.9 & 17 & 0.04 & 0.1 \\
\hline 801B-33R-1, 29-38 cm & late Callovian & $5^{\circ} \mathrm{S}$ & 2.0 & 2.0 & 3.9 & 11 & 0.03 & 0.1 \\
\hline Average of $801 B-33 R-1$ & late Callovian & $5^{\circ} \mathrm{S}$ & 2.0 & 2.0 & 4.9 & 14 & 0.03 & 0.1 \\
\hline $801 \mathrm{~B}-27 \mathrm{R}-1,19-21 \mathrm{~cm}$ & early Tithonian & $0^{\circ}$ & 5.0 & 2.0 & 2.6 & 18 & 0.29 & 2.3 \\
\hline 801B-21R (estimated) & late Tithonian & $0^{\circ}$ & 7.0 & 2.5 & 1.5 & 18 & 0.15 & 2.0 \\
\hline 801B-15R (estimated) & Valanginian & $10^{\circ} \mathrm{S}$ & 11.0 & 2.0 & 2.0 & 31 & 0.25 & 4.3 \\
\hline $800 \mathrm{~A}-52 \mathrm{R}-3,26-29 \mathrm{~cm}$ & Valanginian & $7^{\circ} \mathrm{S}$ & 4.0 & 2.0 & 3.3 & 18 & 0.25 & 1.6 \\
\hline \multicolumn{9}{|l|}{$\begin{array}{l}\text { Other Pacific sites } \\
\text { Site (typical core for age) }\end{array}$} \\
\hline 307-11R (calcareous radiolarite) & middle Berriasian & $6^{\circ} \mathrm{N}$ & 2.0 & 2.0 & 3.0 & 8 & 0.20 & 0.6 \\
\hline 307-8R (siliceous limestone) & middle Hauterivian & $4^{\circ} \mathrm{S}$ & 12.0 & 2.0 & 1.0 & 17 & 0.10 & 1.9 \\
\hline $306-40 \mathrm{R}$ (chert-bearing chalk) & Berriasian-Valanginian & $6^{\circ} \mathrm{N}$ & 10.0 & 1.8 & 1.5 & 19 & 0.10 & 1.4 \\
\hline 306-14R (siliceous limestone) & Barremian & $2^{\circ} \mathrm{S}$ & 15.0 & 1.8 & 1.0 & 19 & 0.10 & 2.1 \\
\hline 167-78R (radiolarian-rich limestone) & Hauterivian & $16^{\circ} \mathrm{S}$ & 10.0 & 2.0 & 0.5 & 7 & 0.05 & 0.8 \\
\hline 304/303A (metalliferous clayey chalk) & early Barremian & $5^{\circ} \mathrm{N}$ & 6.0 & 1.7 & 10.0 & 71 & 0.20 & 1.6 \\
\hline 304/303A (zeolitic claystone) & late Barremian & $4^{\circ} \mathrm{N}$ & 6.0 & 1.7 & 8.0 & 57 & 0.10 & 0.8 \\
\hline 463-83R (siliceous limestone) & late Barremian & $14^{\circ} \mathrm{S}$ & 10.0 & 2.0 & 1.0 & 14 & 0.05 & 0.8 \\
\hline \multicolumn{9}{|c|}{$\begin{array}{l}\text { Pacific Rim exposures of bedded radiolarian cherts } \\
\text { Location }\end{array}$} \\
\hline Inuyama, Japan & Middle-Late Triassic & $0.7^{\circ} \pm 3.4^{\circ}$ & 2.5 & 2.6 & 1.7 & 8 & 0.04 & 0.2 \\
\hline Marin Headlands, California & Early Cretaceous & & 2.0 & 2.6 & 3.1 & 11 & 0.06 & 0.2 \\
\hline Nicoya, Costa Rica & Tithonian-Hauterivian & & 2.0 & 2.6 & 2.6 & 10 & 0.23 & 0.9 \\
\hline Cedros Island, Baja, Mexico & Middle-Late Jurassic & $12^{\circ} \mathrm{N} \pm 5^{\circ}$ & 0.7 & 2.6 & 3.5 & 4 & 0.04 & 0.1 \\
\hline
\end{tabular}

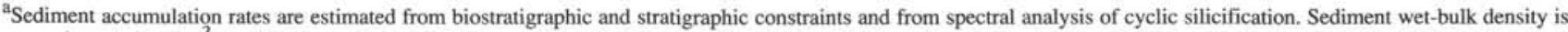
approximately $2 \mathrm{~g} / \mathrm{cm}^{3}$ for all these sediments (Shipboard Scientific Party, 1990b, 1990c). This bulk density (porosity) and clay content accounts for the $15 \%-25 \%$ average loss-on-ignition during microprobe analyses (Table 6). Biogenic silica is computed by subtracting silica in clay from total silica, where clay-incorporated silica is considered to be incorporated in Fe-smectites comprising half of the total $\mathrm{Fe}$ and in $\mathrm{Al}-\mathrm{K}$-smectites comprising all the Al. Detrital silica is considered to be insignificant for the purposes of these calculations, but some thin sections indicate up to $5 \%$ quartz silt is present. "Total clay" percentage is the residual after subtracting biogenic silica and half the iron oxide from the average $80 \%$ total weight of element oxides. The bulk compositions for the upper Tithonian bedded chert unit and the Valanginian clayey radiolarite at Site 801 are estimated from similar facies; all other values are from microprobe measurements (Table 6).

${ }^{b}$ Sediment accumulation rates are estimated from biostratigraphic and stratigraphic constraints and from analysis of cyclic sedimentation. Bulk dry density is according to physical properties of similar lithologies at other sites. Bulk compositions of biogenic silica, clay, carbonate, and metal oxides are estimated from core observations, thin-section descriptions and shipboard carbonate analyses; amounts of total $\mathrm{Al}_{2} \mathrm{O}_{3}$ and $\mathrm{SiO}_{2}$ are adjusted to obtain the biogenic silica content and the clay content, which is assumed to be an $\mathrm{Fe}$-smectite (incorporating all $\mathrm{Al}$ ions and half the $\mathrm{Fe}$ ions) and biogenic silica content. Other values as in footnote $a$.

${ }^{\mathrm{c}}$ Apparent average sedimentation rates for radiolarites is the mean of published estimates, a bulk density of $2.6 \mathrm{~g} / \mathrm{cm}^{3}$ (Jenkyns and Winterer, 1982) is assumed unless given otherwise. Inuyama bedded chert-bulk chemistry from Matsumoto and lijima (1983) assuming their analyzed shale partings comprise $10 \%$ of the section; age and bulk average accumulation rate from Matsuda and Isozaki (1991); paleolatitude is from Shibuya and Sasajima (1986). Cedros Island bedded chert-bulk chemistry from Rangin et al. (1981) adjusted to yield average outcrop lithology of $20 \%$ mudstone (Sedlock and Isozaki, 1990); age and average accumulation rate from Sedlock and Isozaki (1990); paleolatitude of accretion (mid-Cretaceous event) is from Hagstrom and Sedlock (1990, 1991). Marin Headlands (Franciscan Formation) bedded chert-bulk composition is computed from adjacent chert/shale samples in the Lower Cretaceous portion with chert:shale ratio of 2.3:1 (Karl, 1984); average sedimentation rate is from Hein and Karl (1983). Nicoya Complex, Costa Rica-bulk composition is computed from average chert/shale analyses with typical chert:shale ratio of 3.5:1 (Hein et al., 1983); average thickness and age span of their outcrops is from Gursky and Schmidt-Effing (1983).

ner imagery, geochemical-geophysical logs, recovered sediments, apparent dips, and sedimentation rates indicate that this interval comprises two main subunits: a chert-rich lower Subunit IVB-2, and a clay-rich upper Subunit IVB-1 (Fig. 2). Each subunit has considerable internal variability in bedding, in clay content, and in silicification horizons.

\section{Middle Oxfordian to Lowest Tithonian (439-412.5 mbsf; Cores 801B-31R to middle -26R; Lithologic Subunit IVB-2)-Interbedded Brown Chert and Clayey Radiolarite}

Callovian/Oxfordian Facies Change. There is a distinct boundary between the Callovian (Lithologic Unit V) and the Oxfordian (Lithologic Unit IV):

1. Callovian radiolarian claystones are red in color, whereas the Oxfordian and younger clayey radiolarites are brown. The abundance of $\mathrm{Fe}$ decreases by half, whereas $\mathrm{Mn}$-oxide becomes relatively abundant.
2. Characteristic sedimentary structures change from alternating layers in the Callovian of claystone and radiolarite, to a more homogeneous clayey radiolarite in the Oxfordian, in part due to increased bioturbation mixing. Burrow fills and sediment color suggest a slightly greater organic component than in the underlying red Callovian strata.

3. Apparent dip of bedding changes from $20^{\circ}$ in the Callovian to $10^{\circ}$ in the Oxfordian. This $10^{\circ}$ dip continues through Lithologic Subunit IVB-2.

4. Formation MicroScanner images show that the contact zone consists of an indistinct 1-m zone lacking sedimentary structures. The lithologic unit boundary is placed between 439.4 and $439.1 \mathrm{mbsf}$ (Molinie and Ogg, this volume).

5. Radiolarian assemblages from the top of Core 801B-33R and recovery in Core $801 \mathrm{~B}-32 \mathrm{R}$ indicate that the Cinguloturris carpatica radiolarite Zone of middle and late Oxfordian is overlying the lower subzone of the Stylocapsa(?) spiralis Zone of late Callovian (Shipboard Scientific Party, 1990c; Matsuoka, this volume). There is an apparent hiatus encompassing the upper Stylocapsa(?) spiralis Zone, as indicated by the absence of co-occurring Stichocapsa naradanien- 
Table 7 (continued).

\begin{tabular}{|c|c|c|c|c|c|c|c|c|c|c|}
\hline $\begin{array}{l}\mathrm{Al}_{2} \mathrm{O}_{3} \\
(\%)\end{array}$ & $\stackrel{\mathrm{Al}}{\left(\mathrm{g} / \mathrm{cm}^{2} / \mathrm{m} . \mathrm{y} .\right)}$ & $\begin{array}{l}\mathrm{SiO}_{2} \\
(\%)\end{array}$ & $\begin{array}{c}\mathrm{Si} \\
\left(\mathrm{g} / \mathrm{cm}^{2} / \mathrm{m} . y .\right)\end{array}$ & $\begin{array}{l}\mathrm{SiO}_{2} \\
\text { in clay }\end{array}$ & $\begin{array}{l}\text { Biogenic } \\
\text { silica }(\%)\end{array}$ & $\begin{array}{l}\text { Biogenic silica } \\
\left(\mathrm{g} / \mathrm{cm}^{2} / \mathrm{m} . \mathrm{y} .\right)\end{array}$ & $\begin{array}{l}\text { Clay } \\
(\%)\end{array}$ & $\begin{array}{r}\text { Biogenic silica } \\
\text { vs, clay (\%) }\end{array}$ & $\begin{array}{c}\mathrm{CaCO}_{3} \\
(\%)\end{array}$ & $\begin{array}{c}\mathrm{CaCO}_{3} \\
\left(\mathrm{~g} / \mathrm{cm}^{2} / \mathrm{m} . \mathrm{y} .\right)\end{array}$ \\
\hline 3.6 & 9 & 29.2 & 65 & 18.0 & 11.2 & 54 & 33.9 & 0.3 & 16.1 & 77 \\
\hline 5.5 & 12 & 62.1 & 116 & 10.2 & 51.9 & 208 & 20.1 & 2.6 & & \\
\hline 5.7 & 12 & 61.2 & 114 & 11.1 & 50.1 & 200 & 21.7 & 2.3 & & \\
\hline 3.1 & 7 & 62.9 & 117 & 6.5 & 56.4 & 226 & 12.7 & 4.4 & & \\
\hline 4.4 & 9 & 62.1 & 116 & 8.8 & 53.3 & 213 & 17.2 & 3.1 & & \\
\hline 3.9 & 20 & 70.5 & 329 & 6.4 & 64.1 & 641 & 12.7 & 5.1 & & \\
\hline 2.0 & 19 & 80.0 & 654 & 3.4 & 76.6 & 1340 & 6.8 & 11.2 & v & \\
\hline 4.0 & 47 & 73.0 & 750 & 6.1 & 66.9 & 1471 & 12.3 & 5.5 & & \\
\hline 5.1 & 22 & 72.1 & 269 & 8.4 & 63.7 & 510 & 16.7 & 3.8 & & \\
\hline 2.5 & 5 & 70.1 & 131 & 5.1 & 65.0 & 260 & 10.0 & 6.5 & 25 & 100 \\
\hline 1.5 & 19 & 42.5 & 476 & 2.5 & 40.0 & 959 & 5.0 & 8.0 & 55 & 1320 \\
\hline 2.5 & 24 & 19.0 & 160 & 4.0 & 15.0 & 269 & 8.0 & 1.9 & 75 & 1350 \\
\hline 1.5 & 22 & 57.5 & 725 & 2.5 & 55.0 & 1485 & 5.0 & 11.0 & 40 & 1080 \\
\hline 6.0 & 64 & 12.4 & 116 & 7.4 & 5.0 & 101 & 15.0 & 0.3 & 80 & 1600 \\
\hline 11.0 & 59 & 40.3 & 192 & 20.3 & 20.0 & 204 & 40.0 & 0.5 & 30 & 306 \\
\hline 24.8 & 134 & 54.8 & 261 & 34.8 & 20.0 & 204 & 70.0 & 0.3 & 0 & 0 \\
\hline 3.6 & 38 & 20.0 & 187 & 5.0 & 15.0 & 301 & 10.0 & 1.5 & 70 & 1400 \\
\hline 3.8 & 13 & 90.7 & 275 & 5.7 & 85.0 & 553 & 11.4 & 7.5 & & \\
\hline 4.4 & 12 & 87.0 & 211 & 7.4 & 79.6 & 414 & 14.7 & 5.4 & & \\
\hline 4.1 & 11 & 86.8 & 211 & 6.7 & 80.1 & 417 & 13.2 & 6.1 & & \\
\hline 4.0 & 4 & 87.0 & 69 & 7.3 & 79.7 & 135 & 14.3 & 5.6 & & \\
\hline
\end{tabular}

sis and Stylocapsa(?) spiralis, and probably the lower portion of the Cinguloturris carpatica Zone. This radiolarian biostratigraphy assumes that the ranges of taxa at Site 801 are similar to the ranges of taxa in Japan. The biostratigraphic hiatus corresponds to the upper portion of Tethys radiolarian Zone A2 (Baumgartner, 1984, 1987), indicating that the lithologic boundary corresponds to a major hiatus at the Callovian-Oxfordian boundary (Matsuoka, this volume).

These observations imply that the boundary between the Callovian and $\mathrm{Oxfordian}$ is a disconformity or unconformity. The earliest Oxfordian is absent, and the hiatus possibly encompasses much of the latest $\mathrm{Cal}-$ lovian through middle Oxfordian. The base of the Pseudodictyomitra primitiva radiolarian Zone, corresponding approximately to the Oxfordian/Kimmeridgian boundary, is placed in Core 801B-31R, or less than $6 \mathrm{~m}$ above the unconformity (Shipboard Scientific Party, 1990c; Matsuoka, this volume). Therefore, either the Oxfordian is represented by very slow sedimentation, or most of the Oxfordian is absent.

Stratigraphy and Lithology. The age span of Lithologic Subunit IVB-2 is poorly constrained by paleontology. The first occurrence of the radiolarian Pseudodictyomitra carpatica, and corresponding base of this next higher radiolarian zone, is between Cores 801B-21R and 20R (Shipboard Scientific Party, 1990c; Matsuoka, this volume). Therefore, Cores $801 \mathrm{~B}-31 \mathrm{R}$ through $-21 \mathrm{R}$ are assigned to an undifferentiated Kimmeridgian to middle Tithonian. A diverse nannofossil assemblage was recovered in Section 801B-25R-CC, enabling assignment to the Hexalithus noelae Subzone of Bralower et al. (1989), which spans magnetic polarity chrons of upper M20r through lower M19n of middle Tithonian. The presence of the short-ranging nannofossil Umbria granulosa minor further limits the age assignment in this sample to the upper half of this subzone, corresponding to upper M20n through lower M19n (Bralower et al., 1989). Occurrence of nannofossil Polycostella beckmannii in Core 801B-26R-CC (Shipboard Scientific Party, 1990c) implies an age not older than magnetic polarity chron M21 of middle Tithonian (Ogg et al., 1991). Spectral analysis of silicification horizons within Lithologic Subunit IVB-2 yielded a possible, but unreliable, sedimentation rate of $14.5 \mathrm{~m} / \mathrm{m} . y$. (Molinie and $\mathrm{Ogg}$, this volume), suggesting that the $27 \mathrm{~m}$ may only encompass about 2 m.y. of accumulation, although the age span may be greater. Formation MicroScanner imagery suggests a possible discontinuity in sedimentation at $419.4 \mathrm{mbsf}$ (Molinie and Ogg, this volume), corresponding to the top of Core 801B-28R. This array of age and stratigraphic constraints suggests that Lithologic Subunit IVB-2 encompasses late Oxfordian through middle Tithonian (M20), or an age span of approximately $8-9$ m.y. However, the biostratigraphy suggests that the majority of the Kimmeridgian may be absent. Compensating for a possible hiatus at $419.4 \mathrm{mbsf}$, we will use a mean of $5 \mathrm{~m} / \mathrm{m}$.y. for the calculation of elemental mass accumulation rates.

Recovered sediments from these cores are dark brown and consist of chert and of clayey radiolarite to radiolarian-rich claystone. Light yellowish brown to pink mottling and banding commonly cuts across burrows and laminations and is probably due to localized post-burial reduction and migration of $\mathrm{Mn}$. $\mathrm{Mn}$ - and Fe-oxide also occur as scattered micronodules, as black flecks and streaks in the radiolarite, as dendritic coatings on fractures, and as coatings and replacement of radiolarian tests.

The less-silicified radiolarites commonly exhibit a streaky, discontinuous-laminated, "woody" texture (Figs. 7A and 7B). Clearly delineated burrows or continuous laminations are less common. This texture is probably the result of bioturbation, especially by subhorizontal burrows, followed by compaction.

Chert or porcellanite occurs as secondary lenses or distinct beds of silicified radiolarite. The chert is typically darker brown than the host radiolarite, and commonly has reddish brown coloration in mottles, lenses, burrows, and adjacent to fractures. Mn-oxide micronodules occur within the chert, indicating that chert-nodule formation followed Mn precipitation. $\mathrm{Mn}$ is probably the major contributor to the brown color.

Formation MicroScanner imagery enables observation of the thickness and spacing of these chert-rich horizons (Molinie and Ogg, this 

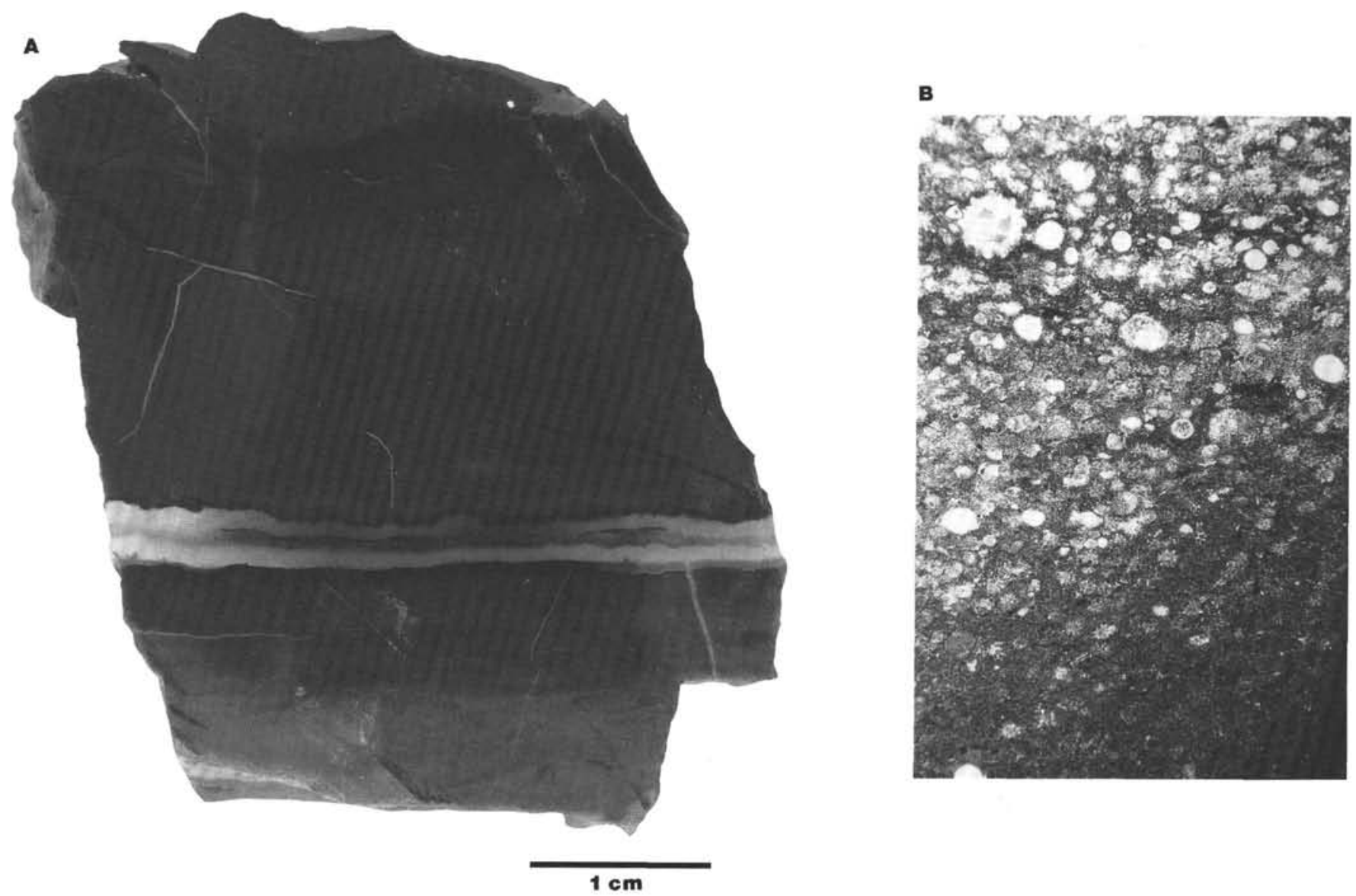

Figure 8. Late Tithonian facies, Site 801. A. Upper Tithonian silicified radiolarite from the bedded chert Subunit IVA-3. Chert is dark brown and displays a pre-silification texture of a bioturbated radiolarite. Other fragments from this facies display drusy quartz-lined fractures and vugs. This bedded chert facies formed when Site 801 was at the paleoequator. Interval 129-801B-22R-CC (entire recovery of core). B. Photomicrograph of silicified radiolarite from the bedded chert Subunit IVA-3. Radiolarians are present either as microcrystalline quartz- or chalcedony-filled molds or as deformed "ghosts." Vague planar lamination is tilted upward in lower right portion of photomicrograph due to compaction over an earlier silica-concretion (off photograph). The more compacted sediment has experienced the greatest dissolution of radiolarians, leaving a clay-rich residue. Silica from the dissolution zone has reprecipitated in the more distant radiolarite. Photomicrograph in plane light, $4 \times$ magnification (width of view is $2.0 \mathrm{~mm}$ ). Interval $129-801 \mathrm{~B}-21 \mathrm{R}-1,6-7 \mathrm{~cm}$.

volume). In the lowest $7 \mathrm{~m}$ of Subunit IVB-2, corresponding to the uppermost Oxfordian and possibly lowest Kimmeridgian, chert-rich zones, 4-7 cm thick, are spaced approximately $15-30 \mathrm{~cm}$ apart. The overlying $20 \mathrm{~m}$ commonly have sets of chert beds spaced every $1.0-1.2 \mathrm{~m}$. Each set spans about $1 / 2 \mathrm{~m}$ and consists of a central cluster of one to three major chert beds, $5-10 \mathrm{~cm}$ thick, bordered by thinner chert beds. If these sets represent the 95 k.y. -123 k.y. eccentricity-cycles (Molinie and Ogg, this volume), then a 1.2-m silicification wavelength corresponds to a sedimentation rate of approximately $13 \mathrm{~m} / \mathrm{m}$.y. Between these chert concentrations, the clay-rich, partially silicified radiolarite has lenticular or irregular siliceous bands spaced an average of $15 \mathrm{~cm}$ apart. The top of Subunit IVB-2 is a chert-poor interval, $2.5 \mathrm{~m}$ thick, at $416.9-419.4 \mathrm{mbsf}$, followed by a 1.7 -m-thick set of chert beds at 412.3-414 mbsf. The alternating chert- and clay-rich lithologies was responsible for the very poor recovery during drilling. There is a general upward increase in the average amount of silicification (Fig. 2) and in the spacing of chert-rich clusters. This trend suggests an upward increase in the flux of radiolarians and an acceleration of overall sedimentation rates.

Recovered sediments have an apparent dip of $10^{\circ}$, which exceeds the $2^{\circ}$ deviation of the drill string from vertical. Dipmeter logs confirmed that the Upper Jurassic strata have dips decreasing upward from $14^{\circ}-7^{\circ}$, oriented toward the southwest. In contrast, recovered sediments and dipmeter logs indicate that the overlying Lower Cre- taceous sediments dip only $2^{\circ}-4^{\circ}$ toward the southwest (Molinie and Ogg, this volume).

Microfacies. Radiolarians, either as tests filled by microcrystalline quartz or as partially-dissolved relict tests and "ghosts," constitute about $5 \%-25 \%$ of the radiolarian-rich claystone intervals, and about $50 \%-60 \%$ of the clayey radiolarite to porcellanite intervals. Distribution of radiolarians in both lithologies is very patchy, and contributes to the "woody" texture (Fig. 7B). There is generally a visual distinction between the populations of silica-filled radiolarian molds and of dissolved ghosts. The proportion of silica-filled radiolarians relative to ghosts is higher in the clay-rich intervals than in the radiolarite layers, and these silica-filled radiolarians generally also have better preserved tests within the clay-rich intervals. In the radiolarite intervals, the poorly preserved radiolarian ghosts are identified as radiolarian-sized patches of microcrystalline quartz. The total abundance of microcrystalline silica, either as filled radiolarians or as partial infilling or replacement of corroded tests and or ghosts, is estimated as $15 \%$ in the typical clay-rich layer and $45 \%$ in the typical radiolarite. A multistage redistribution of silica is indicated by early filling of a few scattered radiolarian tests, formation of ghosts and partial silicification of relict tests in the radiolarite layer, late-stage local silification of the matrix to form porcellanite or chert lenses, and formation of silica-filled vein fractures.

FeMn-oxides occur in the clay-rich intervals predominantly as finesilt-sized particles, either dispersed or as wispy stringers (Fig. 7B). 
These fine particles are much less common in the radiolarian-rich intervals, but the greater abundance of FeMn micronodules and/or clusters of silt-sized granules in these radiolarian-rich intervals imply that the average abundance of FeMn remains constant. Some FeMn occurs as coatings or replacement of silica-filled radiolarian tests.

The characteristic "woody" fabric of this facies (Figs. 7A and 7B) is caused by the combination of several features: (1) Wispy, semi-diffuse concentrations of clay, enriched in fine-silt-sized semi-opaque "RSO"-type reddish Fe-oxyhydroxides. These thin lenses and stringers are typically $0.5-1.0 \mathrm{~mm}$ long, poor in radiolarians and black Mn-oxide, locally deformed around radiolarians, and can occur in larger patches comprising reddish mottles. (2) Wavy elongate clusters and stringers of FeMn-oxide granules, typically about $0.1 \mathrm{~mm}$ long, and most common in clay-rich layers. (3) Plastically deformed ghosts of compacted radiolarians. (4) Patchy distribution of radiolarians and clay at the $1-3 \mathrm{~mm}$ scale, coupled with color mottling from redistribution of Mn-oxide. (5) Formation of anastomosing clay-rich and FeMnrich seams and rare compaction stylolites around silicified radiolarite concentrations. In addition to the woody fabric, this facies has irregular banding at the 5-15 cm scale as clay-rich or radiolarian-rich layers or lenses. Planar lamination is absent, but some radiolarian-rich layers exhibit a vague cross-lamination. The "woody" texture is less developed in the radiolarian-rich layers. The initial clayey radiolarite was an irregular bioturbated distribution of radiolarians and clay, perhaps affected by bottom currents, which developed the present "woody" fabric of wispy discontinuous-laminations largely as a result of diagenetic compaction and of differential migration by $\mathrm{Fe}, \mathrm{Mn}$, and silica.

Chemistry. Three microprobe transects, with 120 measurements using a $20-\mu \mathrm{m}$ beam size, were made of a typical "woody"-textured and mottled radiolarian claystone to clayey radiolarite (Sample 801B$27 \mathrm{R}-1,19-21 \mathrm{~cm})$. The bulk composition is predominantly $70.5 \%$ silica, 2.6\% $\mathrm{Fe}_{2} \mathrm{O}_{3}, 0.3 \% \mathrm{MnO}_{2}, 3.9 \% \mathrm{Al}_{2} \mathrm{O}_{3}, 1.1 \% \mathrm{~K}_{2} \mathrm{O}$, and $0.9 \%$ $\mathrm{MgO}$, with loss-on-ignition of $20.2 \%$ (Table 6).

Lighter-colored mottles, which are possibly due to burrows, are the result of a 70\% depletion in $\mathrm{MnO}_{2}$. The mottles have slightly higher $\mathrm{Al}$ and $\mathrm{Fe}$ content, due to the slightly lower abundance of radiolarians. This chemical signature indicates a post-burial migration of $\mathrm{MnO}_{2}$ from the mottle region, presumably due to a mild local reducing condition.

There is considerable variation in $\mathrm{MnO}_{2}$ abundance within the "woody" texture, whereas $\mathrm{Fe}$ remains constant relative to $\mathrm{Al}$. Therefore, many of the dark wispy stringers of opaques within the clayey radiolarite are caused by post-burial precipitation of $\mathrm{MnO}_{2}$.

The rock is very siliceous, despite the visual and microscope classification of "radiolarian claystone." If half of the $\mathrm{Fe}$ and all the $\mathrm{Al}$ were present in the form of smectite clays, then the equivalent silica in these clays would be $10 \%$ of the total silica, and "non-clay" silica would be $65 \%$ of the rock (Table 7). This implies that much of the inter-radiolarian matrix is partially silicified.

$\mathrm{Fe}$ and $\mathrm{Mn}$ constitute approximately $2.6 \%$ and $0.29 \%$, respectively, of this sediment. The Fe/Mn ratio is typically 8 , increasing to 30 in the Mn-poor mottles. When compared to the underlying Callovian, with a Fe/Mn ratio of 100 and $\mathrm{Mn}$ abundance of only $0.03 \%$, this Upper Jurassic sediment is considerably Mn-enriched. In addition, $\mathrm{Fe}$ abundance decreases by half from the Callovian level of $4 \%$. However, the mass-accumulation rate of Fe remains similar to the Callovian, at about $18 \mathrm{~g} / \mathrm{cm}^{2} / \mathrm{m}$.y. due to the higher estimated rate of sedimentation. In contrast, the Mn accumulation rate of $2 \mathrm{~g} / \mathrm{cm}^{2} / \mathrm{m}$.y. is nearly 20 times the Callovian rate.

The character of terrigenous clays $(\mathrm{Al}, \mathrm{K}, \mathrm{Mg}$, and $\mathrm{Ti}$ ratios) is similar to the underlying Callovian sediments. The higher $\mathrm{Al} /(\mathrm{Al}+$ $\mathrm{Fe}+\mathrm{Mn}$ ) ratio of 0.5 , compared to the Callovian ratio of 0.4 , implies that authigenic Fe-smectites are a much less important constituent of these sediments. Hydrothermal contributions diminished as distance from the spreading ridge increased.

These observations are based upon analysis of a single characteristic sample. While representative of the trends, the quantitative values may not be the same as the mean sediment.
Middle Tithonian (412.5-396 mbsf; Upper Core 801B-26R through -23R; Lithologic Subunit IVB-1) - Clayey Radiolarite with Periodic Silicification

Stratigraphy and Lithology. Formation MicroScanner imagery and recovered sediments indicate that this interval is distinctly clayrich relative to underlying and overlying sediments. Semi-quantitative measurements of the degree of bulk silicification (Molinie and Ogg, this volume) suggest that this interval has approximately half as much silica as in the underlying upper portion of Subunit IVB-2 (Fig. 2). Recovered sediments lack the abundance of chert, characteristic of the underlying subunit.

The age within the lower core is constrained by nannofossil data, as cited previously, to be not older than middle Tithonian magnetic polarity chron M20n and not younger than M19n. Paleomagnetic measurements on the recovered sediments indicate predominantly reversed polarity, which may incorporate M19r or M20r (Shipboard Scientific Party, 1990c). Spectral analysis and identification of Milankovitch periodicity yields an estimated accumulation rate of $6.5 \mathrm{~m} / \mathrm{m} . \mathrm{y}$. (Molinie and Ogg, this volume), implying a time span of approximately 2 m.y. for this clay-rich interval, although Formation MicroScanner imagery of silicification characteristics does not support a regular cyclicity throughout. Assembling this array of stratigraphic data, we suggest that this clay-rich interval comprise a relatively short stratigraphic interval within the middle Tithonian, perhaps limited to about 1-2 m.y. of sedimentation during magnetic polarity chrons M20r-M19r. Therefore, the onset of this clay-enriched zone corresponds to the reorganization of spreading ridge orientations and geometry between magnetic anomalies M21 and M20 (Handschumacher et al., 1988; Sager et al., 1988) and to a reversal in the direction of Pacific Plate paleolatitude drift (Fig. 3).

Formation MicroScanner imagery displays a sharp onset of clayenrichment at $412.5 \mathrm{mbsf}$. The lower $7 \mathrm{~m}$ have periodic partial silicification, spaced at about $1 \mathrm{~m}$ intervals, but no major chert beds. Chertification becomes more important in the upper half of the subunit, with a transition to the bedded chert facies of the overlying unit. The uppermost clay-rich bed is at 396 mbsf.

Recovered sediments are predominantly dark brown radiolarian claystone to clayey radiolarite, with lenses of secondary porcellanite or chert (Fig. 7A). Some of the relatively clay-rich horizons contain minor amounts of volcanic glass. Sedimentary structures, "woody" texture, and other features are very similar to the underlying subunit; the main contrast is the increased average clay content.

Microfacies. Radiolarians comprise about $15 \%-25 \%$ of the radiolarian claystone and porcellanites in the lower cores, and locally up to $40 \%$ of the upper cores. Silica-filled radiolarian tests are limited to about $10 \%$ of the sediment (Fig. 7B). Some tests (or spines?) consist of three-lobed dumbbells of silica, with $20-30 \mu \mathrm{m}$ width (approximately one-fourth of the average diameter of a radiolarian); these unusual forms are mainly limited to the upper Tithonian. Radiolarian preservation is better within the upper cores. The clay-rich lower sections contain up to $5 \%$ silt-sized detrital quartz and $15 \%$ fine-siltsized mica. Other characteristics, such as Mn-oxide redistribution, are similar to the underlying subunit.

Significance. This interval of clay-enrichment interrupts the overall trend within the Upper Jurassic toward increasing silica content of the sedimentation, which culminates in the overlying upper Tithonian bedded cherts (Fig. 2). This pulse of clay input coincides with a middle Tithonian (M21-M20) plate reorganization within the western Pacific and possible onset of the Shatsky Rise volcanism (Handschumacher et al., 1988; Sager et al., 1988). Pacific Plate changed direction of drift in the middle Tithonian (Fig. 3; Steiner and Wallick, this volume; B. Wallick, unpubl. data, 1992). Episodes of Pacific Plate reorganization during the Tertiary resulted in an increased hydrothermal activity and a corresponding pulse of higher mass accumulation rates of $\mathrm{Fe}$ and $\mathrm{Mn}$ into sediments at considerable distances from the active ridges (Leinen and Stakes, 1979; Owen and Rea, 1985; Olivarez and Owen, 1989; Rea et al., 1990). 
The accumulation rate of pelagic clay is also very sensitive to changes of global or regional climate and associated transport of eolian dust (Leinen, 1989; Rea, 1990). An association of the Site 801 clay-enrichment interval with increased volcanic activity and eolian influx is supported by shipboard observations of volcanic glass and by the relatively higher abundance of detrital quartz silt. This pulse of clay-enrichment could also record a period of decreased silica sedimentation. The extent of this middle Tithonian clay-enrichment pulse within the Pacific is not known.

\section{Upper Tithonian (396-378 mbsf; Cores 801B-22R to middle of -20R; Lithologic Subunit IVA-3) - Bedded Radiolarian Chert}

Stratigraphy and Lithology. A pronounced interval of $18 \mathrm{~m}$ of bedded chert is the final phase of Upper Jurassic sedimentation at Site 801 . Late Jurassic radiolarian assemblages within the chert (Pseudodictyomitra primitiva radiolarian Zone) indicate that Core 801B-21R cannot be younger than latest Tithonian (Shipboard Scientific Party, 1990c; Matsuoka, this volume). The nannofossil age constraint of middle Tithonian for underlying clay-rich Subunit IVB-1 implies that this overlying bedded chert formation must be late Tithonian in age. Paleomagnetic results indicates reversed polarity within two of the recovered chert pieces. Spectral analysis of Milankovitch cyclicity in the silicification yields an estimated sedimentation rate of $7.5 \mathrm{~m} / \mathrm{m}$.y., implying a time span of approximately 2 m.y. for these bedded cherts (Molinie and Ogg, this volume). All these constraints suggest that deposition may have spanned the 2 m.y. interval between magnetic polarity chrons M20n-M19r-M19n of latest Tithonian.

Formation MicroScanner imagery indicates a rapid upward increase in chert between 396.4 and 393.1 mbsf (Molinie and Ogg, this volume). The next $12 \mathrm{~m}$ are almost entirely silicified, with irregular chert bands that merge, pinch, and swell. Chert beds average $15 \mathrm{~cm}$ thick and range from $5-25 \mathrm{~cm}$ thick. Numerous fractures and vugs are present, especially within the thicker beds. Recovered chert pieces indicate that some of these cavities are lined with drusy quartz, and many of the fractures are quartz- or chalcedony-filled.

The uppermost $5 \mathrm{~m}$ contain less siliceous interbeds, which become progressively thicker and more clay-rich. At $378-377 \mathrm{mbsf}$ there is an apparently rapid transition from chert-dominant to clay-dominant facies, and the few siliceous layers progressively change from bands to nodules. This sudden termination of silica-rich facies corresponds to the boundary to the next overlying radiolarian zone of BerriasianValanginian, and, according to spectral analysis of cycles, is a discontinuity in sedimentation rates.

The recovered chert pieces are very dark grayish brown to dark brown, with tan to yellowish red mottling, streaks, and patches (Fig. 8A). Some fractured pieces display "compartmented" differences in degrees of silicification, indicating that some brecciation occurred prior to complete chertification (Behl and Smith, this volume).

Microfacies. The pre-chertification lithology was a clayey radiolarite. Semi-quantitative log-response estimates of average clay content within this interval is approximately $30 \%-40 \%$, which is the lowest computed clay content of any facies within Hole 801B (Moline and Ogg, this volume). Radiolarians filled by microcrystalline quartz or chalcedony comprise $10 \%-30 \%$ of the recovered chert, with deformed ghosts of former radiolarians having only partial microcrystalline-quartz replacement comprising another $20 \%$. Total visible radiolarian content is patchy, with the most variation being in the ability to distinguish ghosts of former radiolarians.

One thin section (801B-21R-1, 6-7 cm) displays a local compaction of a layer of former radiolarian claystone over a nodule of early-lithified Mn-oxide-rich radiolarite (Fig. 8B). There is a progressive distortion and dissolution of radiolarians within this layer as the degree of compression increases, with an end-product of a silicadepleted seam of FeMn-rich clay directly over the nodule. This compaction-enhanced dissolution of radiolarians affected both silicafilled and partial-ghost forms, with the exception of an Mn-oxide-

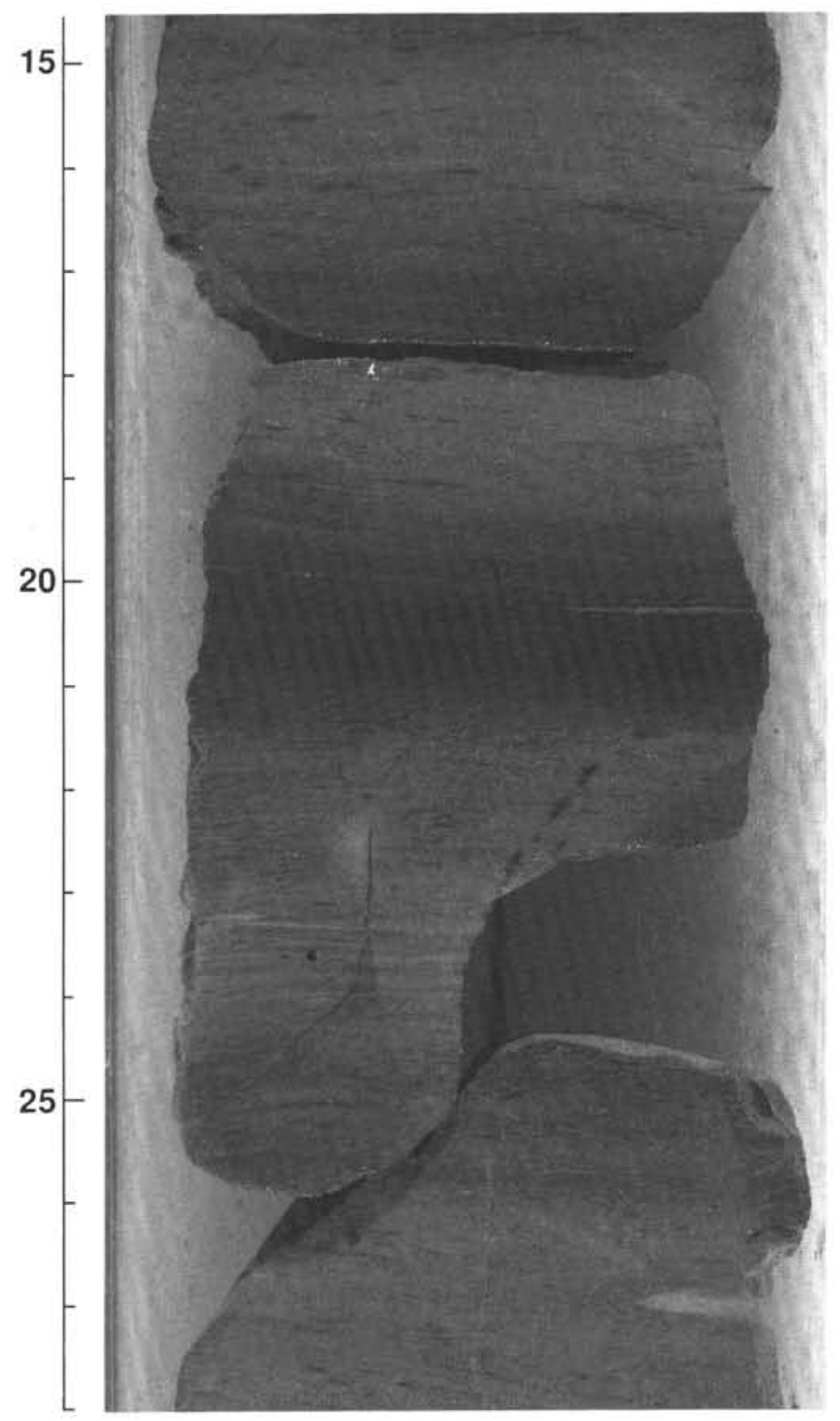

Figure 9. Early Cretaceous facies, Site 801. Upper Berriasian-Valanginian clayey radiolarite displays a "woody" texture similar to that observed in the underlying Upper Jurassic clayey radiolarites (Fig. 7). The discontinuous streaks of FeMn-oxides and of wispy and elongate flaser-like clay concentrations that may be caused by compaction of fine subhorizontal bioturbation. Black streaks and spots are concentrations of FeMn-oxides. Zones of partial silicification, such as the dark brown area at the $20-\mathrm{cm}$ level, are spaced at 5 -cm intervals in Formation MicroScanner imagery. Light mottles are local reduction of Mn-oxide. Interval 129-801B-18R-1, 15-28 cm.

replaced test. The silica migrated from the compaction zone, and appears to have reprecipitated as cement in adjacent radiolarite regions. It is probable that similar dissolution of radiolarians from relatively clay-rich layers during burial and compaction provided some of the silica necessary to create the present chert. The volume of silica that fills radiolarian tests as chalcedony or opal-CT cement suggests that a minimum of 1-3 times as much biogenic silica was completely dissolved and reprecipitated as was replaced and preserved with recognizable structure.

Each successive stage of silicification appears to cause redistribution of silica over progressively larger regions. The first stage is the scattered infilling of radiolarian tests, each surrounded by partially dissolved tests and radiolarian ghosts, which were the source 
of part of the required silica for the infillings. Biosiliceous debris, rather than complete radiolarians, makes up the principle component of most shallowly buried siliceous sediments and is the probable source of most of the earliest free silica, as is observed in younger porcellanites (Behl and Smith, this volume). This stage seems to involve dissolution-migration-precipitation on the scale of less than a millimeter. The second stage is a drawing of silica from relatively clay-rich zones to relatively silica-rich zones during compaction. Radiolarians in the clay-rich zone dissolve, and microcrystalline quartz partially fills the crushed remnants of the radiolarian tests in the silica-rich zones. This redistribution contributes to the observed patchy clustering in radiolarian abundance on the scale of 1-2 mm. The third stage is the dissolution of the former silica-filled radiolarians in the progressively clay-richer zones; the silica migrates to provide silicification of the radiolarite layers, producing the contrast between clay layers and chert layers. This dissolution-migration-precipitation cell seems to operate over the scale of 5-15 cm, the halfspacing of chert beds. The chert layers include silicification of slightly clay-rich patches that were incorporated within the broader zones of chertification. The final stage of silification produced the quartz-lined fractures and vugs and appears to involve intra-bed cannibalization of previously silicified radiolarite, as reflected in the partially dissolved silica-molds in the claystone.

Mn mobilization and precipitation occurred early, prior to the main redistribution of silica. Larger granules of $\mathrm{Mn}$-oxide precipitated within the more radiolarian-rich zones. The process of silicaremoval from the more clay-rich zones resulted in concentration of fine-particle Mn-oxide and Fe-oxide stain within the final clay-enriched products.

Significance. Radiolarite chert formations with wavy-knobby to even "ribbon" bedding are a characteristic Jurassic pelagic sediment exposed around the Pacific margins and in the Tethyan belt (e.g., Jenkyns and Winterer, 1982; Baumgartner, 1987; Hein and Obradovic, 1989). This $18-\mathrm{m}$ unit of bedded radiolarian chert represents the first well-documented occurrence of an in-situ deep-sea equivalent to such radiolarite chert formations. The sedimentary structures of pinch-and-swell and bifurcation of chert beds observed on the Formation MicroScanner imagery, of $15-\mathrm{cm}$ average bedding thickness with a $5-25 \mathrm{~cm}$ range, and of quartz-filled late-stage vugs and fractures within the thicker chert beds are, however, more characteristic of wavy-irregular or "knobby" radiolarite chert, than of the typical "ribbon" even-bedded chert formations. The observations at Site 801 indicate that a well-mixed clayey-siliceous primary deposit is a required precursor for knobby-bedded radiolarian chert formation. In contrast, a ribbon-bedded chert requires a well-stratified primary deposit of alternating radiolarian- and clay-rich layers, which undergoes silica redistribution and enhanced chertification of the radiolarian-rich layers during diagenesis.

\section{Mass Accumulation Rates and Cyclicity of Biogenic Silica}

Site 801 exhibits a progressive increase in biogenic silica flux and associated degree of silicification from Oxfordian to Tithonian. The computed clay vs. biogenic silica of our samples suggests that clay proportion drops from $26 \%$ of the average Callovian radiolarite to $16 \%$ in the lower Tithonian (Table 7). During the late Tithonian, the site reached an equatorial paleolatitude (Table 5) and the sediments consist of bedded chert. Silica content probably attains $85 \%-90 \%$ of the bedded chert unit of the uppermost Tithonian.

Analysis of logs of Site 801 (Fig. 2) reveals that the relative proportion of silica to clay increases upward more significantly than indicated by these few chemical analyses, suggesting that there was a progressive rapid increase in biogenic silica productivity. This increase in siliceous radiolarian input and decrease in clay content corresponds to increased proximity to the equator and increased distance from hydrothermal emissions from the spreading ridges. This progression of silicification was briefly interrupted in the middle
Tithonian by a pulse of clay influx (and possible reduction in radiolarian productivity or preservation) reflecting an increased hydrothermal and volcanic activity associated with the Pacific Plate reorganization and change in drift direction between $\mathrm{M} 21$ and $\mathrm{M} 20$, then resumed the general trend (Fig. 2).

The accumulation rates of the different sedimentary components varied greatly through the Upper Jurassic. Long-term trends of multimillion-year duration, especially the middle Tithonian pulse of clay input, are imprinted on the general trend of increasing radiolarian content. Formation MicroScanner imagery and spectral analysis of logging properties indicate a pronounced cyclicity, at the scale of $1-4 \mathrm{~m}$, in the relative clay abundance and degree of silicification. This cyclicity appears to be caused by Milankovitch climatic cycles, especially eccentricity (Molinie and Ogg, this volume).

Within these 100-400-k.y. cycles of clustered silica-rich beds, the sediments display clay-rich and radiolarian-rich banding with 10-20$\mathrm{cm}$ repetitions. At the millimeter scale, each bed displays a patchy distribution of preserved radiolarians. Both the banding and the patchy variation may be significantly enhanced by diagenetic migration of silica, bottom currents, and bioturbation. The estimated sedimentation rate of $5-7 \mathrm{~m} / \mathrm{m} . \mathrm{y}$. implies that the average $15-\mathrm{cm}$ alternations have an approximate periodicity of $25,000 \mathrm{yr}$, and therefore may incorporate the 20-k.y. cycles of Milankovitch precession.

The accumulation rate of biogenic silica during the Tithonian is approximately $600 \mathrm{~g} / \mathrm{cm}^{2} / \mathrm{m}$.y. This is much more rapid than the modern $100-200 \mathrm{~g} / \mathrm{cm}^{2} / \mathrm{m}$.y. accumulation rate of opal in the eastern equatorial Pacific (Lyle et al., 1988) or the $80-130 \mathrm{~g} / \mathrm{cm}^{2} / \mathrm{m} . y$. accumulation rate of biogenic silica preserved during glacial periods in sediments of the central equatorial Pacific (Rea et al., 1991). However, opal fluxes as high as $1000 \mathrm{~g} / \mathrm{cm}^{2} / \mathrm{m}$.y. have been recorded, such as in Paleocene mid-latitude, open-ocean sediments from the Kerguelen-Broken Ridge Plateau in the Indian Ocean (Rea et al., 1990). This surge at Site 801 in biogenic silica influx and preservation was probably due to the position of the site under the equatorial high-productivity zone. It is estimated that only $1 \%-2 \%$ of radiolarian tests are preserved and buried in modern sediments (De Wever, 1989). Increased silica preservation under the Late Jurassic paleoequator, perhaps due to an increased dissolved-silica content of the ocean waters, may have also contributed to a higher accumulation rate of silica, but the main factor was increased radiolarian productivity.

\section{Mass Accumulation Rates of Metal Oxides and Other Elements}

Microprobe analyses were made of a series of typical radiolarites to determine the distribution of elements between layers and to compute bulk compositions. We combined this data with sedimentation rates derived from spectral analysis of cyclicity or estimated from biostratigraphic and stratigraphic constraints, making it possible to compute mass accumulation rates of various components through time (Table 7). These values indicate the significant trends, but the number of samples is inadequate to derive quantitative data.

Mass accumulation rates can be distorted by local redistribution of sediments. At Site 801, the presence of a series of slumps expanding the uppermost Bathonian-lower Callovian record suggests that the site may be located on a local topographic depression or slope. No slumps were observed within the Upper Jurassic.

Iron. The abundance of $\mathrm{Fe}$, present either as $\mathrm{Fe}$-smectites or as $\mathrm{Fe}$-oxide, steadily decreases upward as a percentage of the sediment. $\mathrm{Fe}$ decreases by half between the Callovian and Tithonian. The amount of $\mathrm{Al}$ remains constant, with $\mathrm{Al}_{2} \mathrm{O}_{3}$ comprising about $4 \%$ of the sediment, except within the middle Tithonian pulse in clay content. Therefore, the upward decreasing ratio of $\mathrm{Fe} / \mathrm{Al}$ indicates that hydrothermal-induced $\mathrm{Fe}$ contribution to the sediment decreases by at least $50 \%$ during the Late Jurassic. The accumulation rate of $\mathrm{Fe}$, however, may not change significantly. The estimated Fe mass-accumulation rate for the lower Tithonian is $18 \mathrm{~g} / \mathrm{cm}^{2} / \mathrm{m}$.y., which is much higher than the $3 \mathrm{~g} / \mathrm{cm}^{2} / \mathrm{m}$.y. of typical Tertiary Pacific sediments 
away from the ridge crest, but about half of the rate on the present East Pacific Rise crest (Leinen and Stakes, 1979).

Manganese. There is an order of magnitude increase in abundance of Mn between the Callovian and Tithonian, and possibly a twentyfold increase in accumulation rate. The Tithonian accumulation rate of $2.3 \mathrm{~g} / \mathrm{cm}^{2} / \mathrm{m}$.y. is half the rate of $5 \mathrm{~g} / \mathrm{cm}^{2} / \mathrm{m}$.y. at the East Pacific Rise, but is much higher than the $0.6 \mathrm{~g} / \mathrm{cm}^{2} / \mathrm{m}$.y. of typical accumulation in sites away from the ridge (Leinen and Stakes, 1979). Tithonian Fe/Mn ratios are consistent with near-ridge metalliferous sediments. As for $\mathrm{Fe}$, the high $\mathrm{Mn}$ accumulation rate is partially due to the continued influence of the ridge. A secondary source could be migration of $\mathrm{Mn}$ from the underlying Mn-depleted Callovian, as was discussed previously.

Rare Earth Elements. Rare earth elements (REE) throughout the Upper Jurassic-Lower Cretaceous sediments are depleted in light components relative to typical pelagic red clays (Karl et al., this volume). REE abundances and the negative cerium anomaly indicate a seawater source for these elements in sediments with subordinate detrital component. The seawater signature is the result of relatively slow sedimentation and of authigenic clays dominating terrigenous clays (Karl et al., this volume).

Aluminum. The abundance of $\mathrm{Al}$, an indicator of terrigenous dust component, decreases only slightly as a proportion of the radiolarite, from $5 \%$ in the Callovian to $4 \%$ in the lower Tithonian. Most of this percentage decline is due to dilution by biogenic silica. Estimates of mass accumulation of $\mathrm{Al}$ indicate a possible doubling between the Callovian to upper Tithonian, when Al accumulates at $20 \mathrm{~g} / \mathrm{cm}^{2} / \mathrm{m}$.y. This rate is higher than average Neogene accumulation rates for $\mathrm{Al}$ in the equatorial Pacific, which are typically less than $5 \mathrm{~g} / \mathrm{cm}^{2} / \mathrm{m} . \mathrm{y}$. (Leinen and Stakes, 1979). Either eolian dust influx from the arid Laurasia-Gondwana landmasses must have been a very significant component of sedimentation in this region of the Pacific, or there was a regional (volcanic?) source of $\mathrm{Al}$-rich clay.

\section{Tithonian Radiolarites at Site 307 and Site 196}

DSDPSite 307 was drilled to basaltic crust of magnetic anomaly M21, implying that the overlying sediments have a maximum age of middle Tithonian. The lower $20 \mathrm{~m}$ of sediment was originally assigned an age of Berriasian-Valanginian, based upon the radiolarian assemblage of the Sphaerostylus lanceola Zone of Riedel and Sanfilippo (1974) (Shipboard Scientific Party, 1975e). Baumgartner (1984) observed that this zone also encompasses the Tithonian, therefore the basal sediment age for Site 307 is probably consistent with the drilled magnetic anomaly.

The uppermost basalt and hyaloclastic debris at Site 307 are highly altered. Fractures with orange oxidation zones penetrate into the greenish-colored, palagonite- and Fe-smectite-rich basalt. Red to yellowishbrown radiolarian chert within brownish-red metalliferous claystone comprises the basal sediment. The chert is nearly homogenized by bioturbation and has extensive FeMn color mottling and dendrites. The basal chert (Sample 307-12R-1, 119-120 cm) is dark reddish-brown, metalliferous silicified clayey radiolarite, consisting of packed silicafilled radiolarian tests within a FeMn-oxide-rich matrix. The next higher core consists of fragments of reddish-brown to light yellowish-brown chert and reddish-brown dolomitic porcellanite with manganese dendrites. The lowest carbonate at Site 307 is approximately $20 \mathrm{~m}$ above basement, and has a Berriasian-Valanginian age.

A single spot-core at DSDP Site 196 may have recovered fragments of Upper Jurassic, but age control is poor. The few pieces consist of dark-colored chert, radiolarian-rich siltstone and radiolarianbearing claystone (Shipboard Scientific Party, 1973b).

\section{Early Cretaceous}

\section{Berriasian-Valanginian Radiolarites at Site 801}

From the Berriasian to middle Valanginian (M18 to M11), the Hawaiian and Japanese ridges maintained fairly stable patterns of seafloor spreading, with the formation of the Shatsky Rise at their junction (Sager et al., 1988). During this period, Site 801 drifted to latitudes $5^{\circ}-8^{\circ}$ south of the equator and subsided to depths of 4000-4300 m (Table 5).

A total of $64 \mathrm{~m}$ of brown clayey radiolarite, comprising Lithologic Subunits IVA-1 and IVA-2, was deposited during this period. The sediments recovered from this Lower Cretaceous unit contain more porcellanite and chert than those of the underlying Upper Jurassic Subunit IVB (Shipboard Scientific Party, 1990c), but this interpretation conflicts with results from geochemical and density-velocity logs, which indicate that the Lower Cretaceous has the same or perhaps less silicification (Fig. 2). These Berriasian-Valanginian radiolarites are bound by hiatuses or rapid facies changes. Formation MicroScanner imagery indicated two main subunits: a clay-rich Subunit IVA-2 overlain by a relatively chert-rich Subunit IVA-1.

\section{Tithonian/Berriasian Facies Change (378-373 mbsf; top of Core $801 B-20 R$ )}

The Jurassic/Cretaceous boundary at Site 801 corresponds to the biostratigraphic boundary between the Pseudodictyomitra primitiva radiolarian Zone and the Pseudodictyomitra carpatica Zone, which is placed between Cores 801B-20R and -21R (Shipboard Scientific Party, 1990c; Matsuoka, this volume). Formation MicroScanner imagery indicates that the upper Tithonian bedded chert is overlain by a $4 \mathrm{~m}$ claystone (377.6-373.2 mbsf) with rare siliceous nodules (Molinie and $\mathrm{Ogg}$, this volume). This claystone interval was interpreted on geochemical logs as a possible "radiolarite with volcanic clay" (Shipboard Scientific Party, 1990c). There was no recovery of this pulse of clay. The underlying uppermost Tithonian displays a rapid upward transition over about $1.5 \mathrm{~m}$ from bedded chert to the claystone. Tithonian strata dip at approximately $7^{\circ}$ to the southwest, whereas the Berriasian-Valanginian strata have shallow dips of $2^{\circ}-4^{\circ}$, mainly toward the southwest and west (Molinie and Ogg, this volume). The change in dip character on the dipmeter log corresponds to this Tithonian-Berriasian boundary at about $378 \mathrm{mbsf}$. Spectral analysis of cyclicity of silicification indicates a disconformity in sedimentation rates from $7.5 \mathrm{~m} / \mathrm{m} . \mathrm{y}$. in the Tithonian bedded chert to $11.5 \mathrm{~m} / \mathrm{m}$.y. in the Berriasian-Valanginian.

These observations indicate an unconformity between the uppermost Tithonian and the overlying Berriasian. This event is characterized by an episode of tilting of the Jurassic strata (rotation above a décollement surface and/or tectonic movement of basement), by deposition of a claystone which may have a volcanic origin, by juxtaposition of biostratigraphic zones, and by a change in sedimentation rates. An unknown amount of Berriasian may be absent, because the next biostratigraphic marker is the middle Valanginian lowest occurrence of radiolarian Cecropus septemporatus in Core 801B-14R, approximately $55 \mathrm{~m}$ higher. Assuming a $11.5 \mathrm{~m} / \mathrm{m}$.y. sedimentation rate for these overlying radiolarites would imply that the early Berriasian is absent in Site 801 .

This Tithonian-Berriasian boundary event may be connected with the voluminous volcanism and possible tectonic disruptions associated with the construction of the southern half of the Shatsky Rise, located about $1500 \mathrm{~km}$ to the north (Fig. 1). The fact that we have stratigraphic data at only one site makes this inference speculative.

\section{Berriasian to Middle Valanginian (373-314 mbsf; Cores 801B-19R to -14R; Lithologic Subunits IVA-2 and IVA-1) - Clayey Radiolarite}

Stratigraphy. The boundary claystone of the Tithonian-Berriasian event is followed by radiolarian claystone with periodic silicification at 1-m intervals. Core recovery from the $15-\mathrm{m}$ interval of this Lithologic Subunit IVA-2 consisted of only a few fragments of brown radiolarian claystone and silicified radiolarite (Fig. 9).

Lithologic Subunit IVA-1 consists of $50 \mathrm{~m}$ of brown, partially silicified clayey radiolarite. The clayey radiolarite is finely banded by chert and porcellanite, typically $2-3 \mathrm{~cm}$ thick, spaced at $5-\mathrm{cm}$ inter- 
A

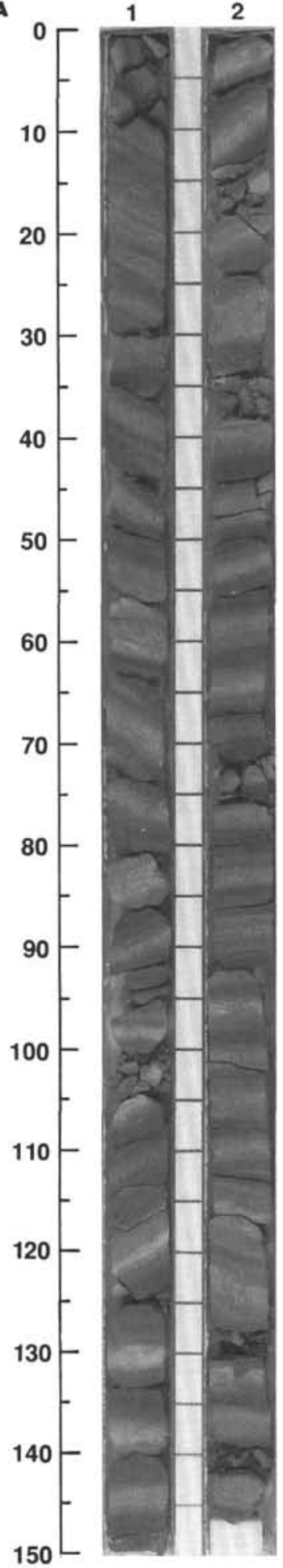

B

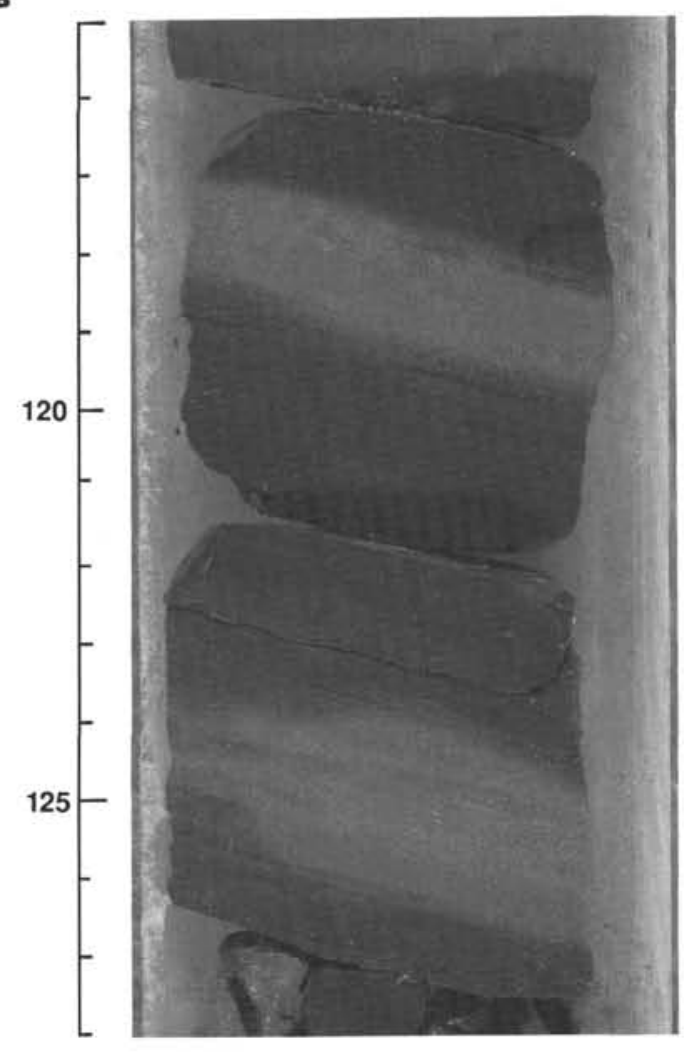

c

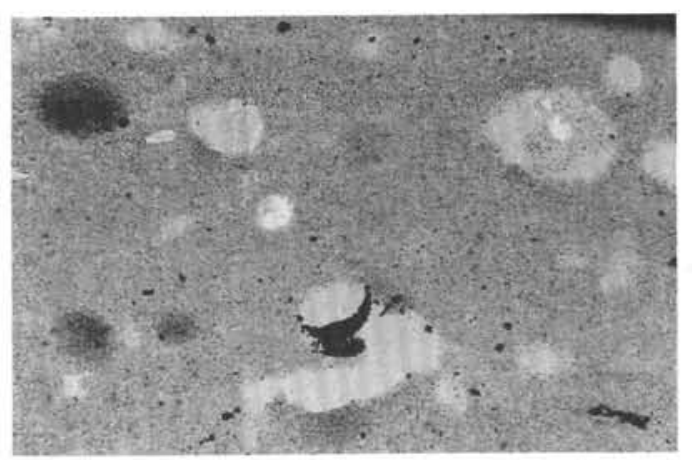

Figure 10. Early Cretaceous facies, Site 800. A. Upper Berriasian clayey radiolarite has alternations of brownish claystone and clayey radiolarite layers with approximately $15-\mathrm{cm}$ spacing. These periodic radiolarian enrichments may represent oscillations of oceanic productivity associated with the $20,000 \mathrm{yr}$ period of Earth's orbital precession. Contrast between clay-rich and radiolarian-rich layers varies, and may reflect the modulation of precession by the $100,000 \mathrm{yr}$ period of Earth's orbital eccentricity Strata have dips of $30^{\circ}$ to $35^{\circ}$. Core $129-801$ B-55R. B. Valanginian clayey radiolarite displaying alternations of claystone (dark brown) with radiolarian-rich layers (light brown). Dissolution of former radiolarians in the clay-rich layers has enhanced the compositional differences. Sediments display a "woody" discontinuous pseudo-lamination similar to that of Site 801 , which seems to be caused by compaction of fine-scale bioturbation. Strata have dips of approximately $20^{\circ}$. Interval $129-800$ A-52R-1, 115-128 cm. C. Photomicrograph of claystone layer of Valanginian clayey radiolarite. Former silica-filled radiolarians in this claystone horizon, which directly overlies a radiolarite, have undergone a late stage of dissolution to produce casts. A fragment of a Mn-oxide-replaced radiolarian test partially encloses a cast at the lower right. The dissolution/reprecipitation of silica has enhanced the compositional differences between layers. This thin-section was used for a microprobe transect (Table 6). Photomicrograph in plane light, 10x magnification (width of view is $1.0 \mathrm{~mm}$ ). Interval $129-800 \mathrm{~B}-52 \mathrm{R}-3,28-29 \mathrm{~cm}$. 
vals (Molinie and Ogg, this volume). Core recovery from this interbedded unit was insignificant-less than $10 \%$ of each cored interval-therefore the stratigraphy is based primarily upon the Formation MicroScanner imagery and other logs. The silicification has minor peaks at about 1-m intervals, and a longer-period alternation of relatively clay-rich and chert-rich zones at about 4- to 5-m spacing. Spectral analysis of this cyclicity is consistent with eccentricity-induced Milankovitch climate periods of 95 k.y., 123 k.y., and 413 k.y., and implies a mean sedimentation rate of $11.5 \mathrm{~m} / \mathrm{m} . \mathrm{y}$. (Molinie and Ogg, this volume). The characteristic $5-\mathrm{cm}$ banding would therefore correspond to intervals of approximately $5000 \mathrm{yr}$. Bedded chert intervals, 6 and $3 \mathrm{~m}$ thick, respectively, are detected at 357.4$351.5 \mathrm{mbsf}$ and at $343.9-340.6 \mathrm{mbsf}$. There is a general upward decrease from $357-316$ mbsf in the abundance of silica and associated average degree of silicification.

Lithology. The recovered sediments consist of dark brown to tan radiolarite with variable concentrations of clay and degrees of silicification (Fig. 9). The radiolarite generally displays discontinuous lamination or "woody" texture, similar to the underlying Upper Jurassic radiolarites (Fig. 7), and a vague rhythmic variation of clay content, radiolarian abundance, partial silicification and color darkness corresponding to the 5 -cm banding observed in the Formation MicroScanner imagery. Mnoxide is abundant as micronodules, black flecks and streaks, and coatings of microfossil tests. Some cherts recovered from the silica-rich intervals are characterized by quartz- or Mn-oxide-filled fractures.

Microfacies of the recovered pieces are dominated by clayey radiolarian porcellanite, with radiolarians typically comprising $20 \%-$ $35 \%$ of the sediment, but up to $60 \%$ in some layers. Radiolarians occur as tests generally filled by microcrystalline quartz or chalcedony or are present as partially silicified molds. The clay-rich matrix is generally highly silicified and contains FeMn-oxides as finely disseminated black specks and reddish fine-silt-sized particles. FeMn oxides comprise about $5 \%-10 \%$ of the sediment. Zeolites are present in amounts from traces to $5 \%$.

Histograms of the Formation MicroScanner images reveal that intervals having high average degrees of silicification also have an increased thickness of the chert beds (Molinie and Ogg, this volume). This correlation suggests that both the thickness and the spacing of silicified beds is partially controlled by the original ratio of clay to radiolarians. When more clay is present, the migration of silica is more inhibited, resulting in thin bands or local nodules of silicification concentrating the silica from shorter distances. Intervals having higher original contents of radiolarians had both an abundant silica supply and higher porosity, thereby enabling growth of thicker chert bands with wider spacing. However, an alternative possibility is that siliceous beds are wider and spaced farther apart because sedimentation rates, especially of radiolarians, are greater within the more siliceous intervals, and therefore the natural periodicity of radiolarianrich and -poor pulses are spaced at greater widths.

Mass Accumulation Rates. The sedimentation rate of $11.5 \mathrm{~m} / \mathrm{m} . \mathrm{y}$. from spectral analysis of Milankovitch cycles is consistent with the biostratigraphic and lithological constraints. Thin-section and macroscopic observations of the recovered silicified clayey radiolarite, when compared to lower Tithonian samples, display slightly lower amounts of FeMn enrichment relative to $\mathrm{Al}$, similar clay content, and a higher silica content. We estimate the average Berriasian-Valanginian sample to consist of approximately $2 \% \mathrm{Fe}_{2} \mathrm{O}_{3}, 0.25 \% \mathrm{MnO}_{2}$, $4 \% \mathrm{Al}_{2} \mathrm{O}_{3}$, and $73 \%$ silica. The increase in sedimentation rate implies that the Berriasian-Valanginian radiolarites have nearly double the rates of mass accumulation for biogenic silica and other elements relative to the similar lower Tithonian facies (Table 7). However, Site 800 , which was closer to the paleoequator than Site 801, displays a lower rate of mass accumulation of biogenic silica during this same time interval (Table 7). Therefore, this computed mass accumulation rate of biogenic silica at Site 801 during the Berriasian-Valanginian is anomalously high. Some possible explanations for these relatively high accumulation rates are (1) actual sedimentation rates were slower than those calculated by spectral analysis of silica cycles (Molinie and Ogg, this volume), (2) the faster accumulation rate of clay at this site enhanced the burial and preservation of biogenic silica, (3) the site experienced local redeposition by bottom currents or distal turbidites followed by bioturbation obliteration of sedimentary structures, and (4) there was a more vigorous southern gyre during the Berriasian-early Valanginian.

\section{Middle Valanginian Termination (316-313 mbsf; Core 801B-13R)}

The uppermost few meters of Lithologic Unit IV (Core 801B-14R) are assigned an age of middle Valanginian. Chert fragments from this Core 801B-14R contain the lowest occurrence of radiolarian Cecrops septemporatus, and corresponding base of that radiolarian Zone (Shipboard Scientific Party, 1990c; Matsuoka, this volume). The upper $2 \mathrm{~m}$, from 315.7 to $314 \mathrm{mbsf}$, have extremely high relative resistivity on the Formation MicroScanner imagery, indicating a well-cemented or highly siliceous sediment, followed by $1 \mathrm{~m} \mathrm{(314-}$ $313 \mathrm{mbsf}$ ) of an extremely high resistivity layer. The interval from 316 to 314 mbsf displays the typical 5-cm banding of Subunit IVA, but the overlying meter of extremely high resistivity is devoid of decipherable sedimentary structures. Geophysical logs display a sharp pulse of total gamma-ray emission, a sharp upward decrease in $\mathrm{Si}$ and $\mathrm{Th}$, and a rise in $\mathrm{K}$ and $\mathrm{U}$. The next core consists of distal volcaniclastic turbidites. There was no recovery of this unique wellcemented feature which terminates the radiolarite, and there is no age from the immediately overlying volcaniclastics. The middle Valanginian termination of radiolarite sedimentation coincides with the M11-M10 age of a reorganization of the Pacific spreading centers and termination of Shatsky Rise volcanism (Sager et al., 1988).

According to the Formation MicroScanner imagery, this middle Valanginian cemented radiolarite is overlain by approximately $13 \mathrm{~m}$ of sediment with 5- to $40-\mathrm{cm}$ banding and low-resistivity contrasts (314-301 mbsf; Lithologic Subunit IIIC) (Molinie and Ogg, this volume). Cores $801 \mathrm{~B}-13 \mathrm{R}$ and $-12 \mathrm{R}$ indicate that this interval consists mainly of greenish-gray, sandy to clayey volcaniclastic turbidites with thin interbeds of radiolarian claystone. This first undated (pre-middle Albian) pulse of volcanic sediment is followed by another $20 \mathrm{~m}$ of clayey radiolarite (301-281.5 mbsf; Lithologic Subunit IIIB), which displays thin-bedded silicification zones similar to the BerriasianValanginian radiolarites. This radiolarite interval, according to Formation MicroScanner imagery, contains a 1-m-thick slump structure and rare volcaniclastic turbidites. No ages were obtained from these radiolarites, but if a $10-\mathrm{m} / \mathrm{m}$.y. sedimentation rate is applied, they represent approximately $2 \mathrm{~m}$.y. A second major series, $155 \mathrm{~m}$ thick, of redeposited volcaniclastics interbedded with minor radiolarites (Lithologic Subunit IIIA) was deposited into the Cenomanian.

The combination of the sudden change in facies from clayey radiolarites to volcaniclastic turbidites, the unusually high resistivity and inferred degree of lithification, and the apparent continuity of sedimentation banding and sedimentation rates up to the termination, suggests that the radiolarite sedimentation was abruptly overwhelmed by the arrival of the distal volcaniclastic turbidites. Part of the abnormal cementation may be the result of lithification associated with a redox interface to the overlying greenish (hence, lower Eh) volcaniclastic turbidites. No precursor volcanigenic sediment beds were observed (except perhaps the anomalous clay-enrichment layer in the basal Berriasian) and there is only minor interbedding of radiolarites within these volcaniclastic turbidites. Therefore, either the volcaniclastic turbidites arrived as a series of close-spaced events within the middle Valanginian, or radiolarite sedimentation had halted prior to the volcanic episode and the exposed seafloor was subjected to a prolonged episode of hardground cementation and/or erosion. Based on comparison with other sites, especially nearby Site 800 , we suggest that the first pulse of volcanic turbidites could be late Barremian or early Aptian in age. 


\section{Middle Berriasian-Valanginian-Lower Hauterivian Radiolarites at Site $\mathbf{8 0 0}$}

Site 800 was drilled on a magnetic anomaly (M33) considered to be Oxfordian in age. Drilling was terminated after penetrating volcanic beds of massive, aphyric, dolerite basalt underlying Berriasian-age radiolarites (Shipboard Scientific Party, 1990b). These volcanics are possibly sills, injected into the Lower Cretaceous strata during the building of nearby Himu or other seamount edifice. The reversed magnetic polarity of the sills suggests intrusion prior to the Cretaceous Quiet Zone, perhaps during the late Barremian-earliest Aptian (Shipboard Scientific Party, 1990b). These volcanics yielded an argon-argon radiometric age date of $126.1 \pm 6 \mathrm{Ma}$ (Pringle, this volume), corresponding to an age of approximately Hauterivian-Barremian on the DNAG time scale.

During deposition of the recovered radiolarite section, Site 800 is estimated to have been located in subequatorial latitudes, $2^{\circ} \mathrm{S}-8^{\circ} \mathrm{S}$, and at depths of $4000-4300 \mathrm{~m}$.

Stratigraphy. The recovered radiolarite section spans approximately $50 \mathrm{~m}$. The stratigraphy is based entirely on the moderate shipboard recovery; logging runs were not possible in this interval. The radiolarite succession of Lithologic Unit $\mathrm{V}$ encompasses portions of three radiolarian zones (Matsuoka, this volume). The Pseudodictyomitra carpatica radiolarian Zone (latest Tithonian to early-middle Valanginian) probably spans the lowest $25 \mathrm{~m}$ from the basal sills through 800 A-54R-2, 98-100 cm. The Cecropus septemporatus Zone (early-middle Valanginian to middle-late Valanginian) extends approximately $12 \mathrm{~m}$ through $800 \mathrm{~A}-52 \mathrm{R}-\mathrm{CC}$. The Dibolachras tytthopora Zone of late Valanginian to earliest Barremian covers the upper $13 \mathrm{~m}$ to the base of the overlying undated initiation of volcaniclastic turbidite deposition. The Cecropus septemporatus radiolarian Zone is estimated to encompass $12 \mathrm{~m}$ of radiolarite and span approximately $3 \mathrm{~m} . \mathrm{y}$, thereby indicating a sedimentation rate of approximately $4 \mathrm{~m} / \mathrm{m}$.y. If this sedimentation rate is applied to the radiolarite sections above and below the Cecropus septemporatus Zone, then the recovered radiolarian section extends from middle Berriasian through earliest Hauterivian. The radiolarites are overlain by redeposited volcaniclastics of early Aptian or older age.

Lithology and Cyclicity. Interbedded within the sills is a thin horizon, $15 \mathrm{~cm}$ thick, of dark reddish brown chert and radiolarite, which display bioturbation mottling and discontinuous laminations. The intersill bioturbated chert (Sample $800 \mathrm{~A}-58 \mathrm{R}-1,37-42 \mathrm{~cm}$ ) is a silicified clayey radiolarite with approximately $55 \%$ radiolarians, half of which are microcrystalline quartz molds and half are indistinct ghosts, in a FeMn-rich matrix. Overlying the volcanic sills is approximately $10 \mathrm{~m}$ of grayish-brown, silicified, bioturbated, radiolarian claystone to clayey radiolarite. Extensive silicification appears to be restricted to the radiolarite in contact with the dolerite sills, suggesting that the hot intrusions induced the formation of chert during contact metamorphism (see discussion of "thermal cherts" in Behl and Smith, this volume).

The Valanginian-lower Hauterivian radiolarite predominantly consists of alternations of reddish-brown clayey radiolarite and of dark brown radiolarian-bearing claystone (Figs. 10A and 10B). There are approximately 15 cycles per meter in the lower Valanginian (Core $800 \mathrm{~A}-55 \mathrm{R})$, decreasing to approximately 10 cycles per meter in the clay-rich upper Valanginian (Cores 51R and 52R). The degree of contrast of claystone vs. radiolarite varies, with maximum contrast occurring at each 4th to 6th cycle (Fig. 10A). Application of the estimated $4-\mathrm{m} / \mathrm{m}$.y. sedimentation rate to the average of 12 alternations per meter implies that these cycles have a periodicity of approximately 21 k.y. Therefore, these alternations in relative abundance of radiolarians and clay were probably produced by Milankovitch precession-induced climatic-oceanographic cycles, which have periods of 19 k.y. and 23 k.y. The variation in clay/radiolarite contrast may be due to the 100-k.y. eccentricity-modulation of the amplitudes of precession effects and to the superposition of the two precession frequencies. An increase in spacing of alternations in the upper clay-rich portion of Lithologic Unit V suggests that sedimentation rates increased prior to the onset of volcaniclastic turbidite deposition.

Radiolarian abundance displays a general upward decrease. The radiolarian-rich layers in the lower cores of the unit consist of $40 \%-$ $60 \%$ radiolarians, in contrast to the $15 \%-25 \%$ radiolarian content of such layers in the upper cores. The abundance of radiolarians in the claystone interbeds remain at about $5 \%-10 \%$. In the uppermost few meters (Core $800 \mathrm{~A}-51 \mathrm{R}$ ), some radiolarians contain partial filling by calcite spar; otherwise calcite is absent.

The brown claystone and radiolarite layers are characterized by fine bioturbation mottling, Chondrites burrows, and wispy lamination, indicating moderately oxygenated bottom conditions and possible slow bottom currents (Fig. 10B). The textural appearance is "woody," similar to the brownish clayey radiolarite of Site 801, but has more evident small-scale bioturbation. The reddish brown coloration of the radiolarite is caused by a combination of Fe-oxide and Mn-oxide. Local reduction of both oxides produces mottles of reddish and of light greenish hues that cut across the banding and wispy lamination; these mottles are mainly present in the upper portion of the radiolarite unit. Mn-oxide-rich dark mottles, black streaks, and dendrites are common. The uppermost cores (800A-51R and -52R) are less brownish in color and have more abundant iron-reduction mottling than the underlying cores, suggesting a lower post-burial oxidation state and possibly increased bioturbation.

The alternating bands display apparent dips of $35^{\circ}$ in the lowest core $\left(800 \mathrm{~A}-55 \mathrm{R}\right.$; Fig. 10A) decreasing to $20^{\circ}$ in higher cores. The overlying lower portion of the volcaniclastic turbidites also displays contacts dipping at $10^{\circ}-20^{\circ}$. The cause and timing of this apparent tilting is not known, but could indicate rotation above a basal décollement surface or a late-stage basement tilting.

Microfacies of Alternations between Radiolarite and Claystone. Thin-section and microprobe geochemical transects were made across alternating layers of radiolarian-rich claystone and of clayey radiolarite (Fig. 10B). In radiolarian-rich layers, approximately half the radiolarians are filled with microcrystalline quartz or chalcedony; the rest are partially silicified infillings of dissolved tests. In contrast, many of the radiolarians within the claystone layers are only recognized by distinctive radiolarian-shaped voids, some with partial Mnreplacement of former tests (Fig. 10C). These hollow casts of dissolved radiolarians are most abundant in the portion of the claystone layer that is directly adjacent to a radiolarite layer. With increasing distance from the radiolarite layer, the claystone displays a decreasing abundance of radiolarian ghosts and rare silica-filled molds. Some of these narrow transition intervals retain a mixed population of silica-filled radiolarians and dissolved radiolariancasts. These observations imply that silica was dissolved from the claystone adjacent to the radiolarite and reprecipitated in the radiolarite, converting a former gradational transition between radiolarianpoor and -rich layers into a sharp boundary.

Radiolarian-rich layers contain a higher abundance of Mn than the adjacent claystone layers, but $\mathrm{Fe}$ remains constant relative to $\mathrm{Al}$. One microprobe transect (Sample 800A-52R-3, 26-29 cm) indicated that the radiolarite layer has $0.44 \% \mathrm{MnO}_{2}$ vs. only $0.06 \%$ in the overlying claystone (Table 6). The ratio of $\mathrm{Al} /(\mathrm{Al}+\mathrm{Fe}+\mathrm{Mn})$ remains constant at 0.51 , even though there is $25 \%$ more $\mathrm{Al}$ in the claystone layer. The silica-depleted boundary between the radiolarite and the claystone transition has the highest concentration of $\mathrm{Mn}$, averaging $2.4 \% \mathrm{MnO}_{2}$, and appears in some other thin sections as a metalliferous claystone. Mn has preferentially precipitated within the radiolarite, and has also been concentrated near the diagenetic enhancement boundary to the adjacent claystone. The $\mathrm{Fe} / \mathrm{Mn}$ ratio is 60 within the claystone in contrast to 6 within the radiolarite layer, suggesting that $\mathrm{Mn}$ has migrated from the claystone into the radiolarite.

The claystone and clay-rich matrix within the radiolarite has abundant (up to $20 \%$ ) fine-silt-sized mica. Fe is present mainly as dispersed clay-sized black particles and reddish "RSO"-type semi- 
opaque fine-silt-sized globules of Fe-oxide/hydroxide, generally comprising about $10 \%$ of the claystone. Traces of zeolites and fish bones are also present.

Mass Accumulation Rates. The average oxide abundances of the radiolarite-rich layer and the claystone layer of the typical sample from Core $52 \mathrm{R}$ are $72.1 \%$ silica, $5.1 \% \mathrm{Al}_{2} \mathrm{O}_{3}, 3.3 \% \mathrm{Fe}_{2} \mathrm{O}_{3}$, and $0.25 \% \mathrm{MnO}_{2}$. Based upon the sedimentation rate of $4 \mathrm{~m} / \mathrm{m}$.y., the mean mass accumulation rates for the Valanginian are approximately $20 \mathrm{~g} / \mathrm{cm}^{2} / \mathrm{m}$.y. for both $\mathrm{Fe}$ and $\mathrm{Al}, 2 \mathrm{~g} / \mathrm{cm}^{2} / \mathrm{m}$.y. for $\mathrm{Mn}$, and $500 \mathrm{~g} / \mathrm{cm}^{2} / \mathrm{m}$.y. for biogenic silica (Table 7). The average clay content is approximately $20 \%$ of the sediment.

In general, the proportions of $\mathrm{Fe}, \mathrm{Mn}, \mathrm{Al}$, clay, and biogenic silica are comparable to the Valanginian of Site 801; however, the estimated sedimentation rate, hence mass accumulation rate, is approximately one-third as great. As noted previously, it is possible that Site 801 experienced anomalously high rates of sedimentation during this interval.

Sediment Facies vs. Paleolatitude. The upper portion of the radiolarites have a wider spacing of cyclic alternations of radiolarite and claystone relative to the lower portion ( 10 cycles per meter vs. 15 per meter). If this quasi-cyclic bedding is driven by Milankovitch climate cycles, then the sedimentation rates of the upper Valanginian-lower Hauterivian are $50 \%$ greater than in the upper Berriasian. Thin-section observations and shipboard smear slides indicate that the lower portion of the unit has perhaps two to three times the relative abundance of radiolarians within the radiolarite-rich layers. Therefore, the mass accumulation rate of biogenic silica in the form of radiolarians decreased slightly from the Berriasian through the Valanginian, whereas the clay accumulation rate increased significantly. These trends are consistent with the passage of the Site from a Berriasian near-equatorial high-productivity location at approximately $2^{\circ} \mathrm{S}$ to a Hauterivian tradewind belt location at approximately $8^{\circ} \mathrm{S}$ (Table 5). The site apparently had more detrital clay input as it passed into the tradewind belt.

\section{Lower Cretaceous Sediments at Other Pacific Sites}

Sites 801 and 800 provide a record of the deepest portions of the Pacific, and the Lower Cretaceous pelagic sedimentation consists entirely of FeMn-rich clayey radiolarites governed by latitude and influenced by Milankovitch cycles. Other Pacific DSDP sites indicate that carbonate was being preserved at shallower depths on the spreading center and on oceanic plateaus. We examined the record of these Lower Cretaceous sediments in the cores and in thin section. This summary will concentrate on two main factors: mass accumulation rates of components and presence of cyclicity.

\section{Site 196 (M24, Japanese Magnetic Lineations)—Berriasian through Barremian Siliceous Limestones}

The Lower Cretaceous at Site 196 consisted of only two widely spaced spot cores. The Berriasian-Valanginian recovery consists of white, homogeneous, radiolarian-bearing $(10 \%-15 \%)$ micritic limestone, and fragments of chert and radiolarian claystone. These siliceous sediments were deposited when the site was at approximately $2^{\circ}-5^{\circ} \mathrm{S}$ latitude and at a paleodepth of $4000 \mathrm{~m}$ (Table 5). Sedimentation rates must have exceeded $10 \mathrm{~m} / \mathrm{m} . \mathrm{y}$. for much of the BerriasianValanginian, but this database is inadequate to compute rates for any specific stage.

\section{Site 307 (M21, Hawaiian Magnetic Lineations)—Berriasian through Barremian Siliceous Limestones}

Site 307 discontinuously cored a succession of Berriasian through Barremian chert-rich limestones (Cores 307-11R through -6R) overlying noncalcareous metalliferous radiolarian claystone (Core 12R). All sediments are bioturbated, with either subplanar compacted burrow-mottles or homogenized, massive beds. Nearly all intervals are reddish colored, but FeMn-oxides are sparse in thin sections of the cherty limestones. The recovery was biased towards reddish chert, formed by the silicification of a radiolarian-rich $(10 \%-30 \%)$ chalk precursor, but the cores contain pieces of radiolarian-rich micritic limestone, which is probably the host sediment for the chert concretions. Volcanic ash is present in lower Aptian sediments (Core 307-5R).

Sedimentation rates are difficult to estimate due to the discontinuous recovery, but shipboard nannofossil stratigraphy indicates about $2-3 \mathrm{~m} / \mathrm{m}$.y. during the Berriasian-middle Valanginian (Cores 307-11 R and $-10 \mathrm{R}$ ) when the site was approaching the equator, and possibly $10-20 \mathrm{~m} / \mathrm{m} . \mathrm{y}$. during the late Valanginian-Hauterivian (Cores $9 \mathrm{R}$ through $7 R$ ) when the site was under the equator. The recovery indicates a general upward increase in carbonate from Cores $11 \mathrm{R}$ to $7 \mathrm{R}$. A carbonate analysis of a typical siliceous limestone (Sample 307-9R-1, $148 \mathrm{~cm}$ ) yielded $26 \% \mathrm{CaCO}_{3}$ (Bode, 1975). Thin-sections indicate that even the limestone intervals contained up to $40 \%$ radiolarians, now largely replaced by micrite or infilled by microcrystalline quartz or chalcedony (Sample 7R-1, 59-61 cm). For mass accumulation estimates, we assumed a middle Berriasian (Core 11R) sedimentation rate of $2 \mathrm{~m} / \mathrm{m} . \mathrm{y}$. of $60 \%$ biogenic silica, $25 \%$ carbonate, $10 \%$ clay and $3 \% \mathrm{Fe}_{2} \mathrm{O}_{3}$, and a middle Hauterivian (Core 7R) sedimentation rate of $12 \mathrm{~m} / \mathrm{m} . \mathrm{y}$. of $40 \%$ biogenic silica, $55 \%$ carbonate and $10 \%$ clay. Such assumptions would imply that the rate of biogenic silica accumulation would increase by a factor of 4 between the Berriasian and Hauterivian, reaching about $900 \mathrm{~g} / \mathrm{cm}^{2} / \mathrm{m} . \mathrm{y}$. during the equatorial crossing, while carbonate increases by an order of magnitude, exceeding $1300 \mathrm{~g} / \mathrm{cm}^{2} / \mathrm{m}$.y. at the equatorial crossing.

Carbonate preservation and sedimentation rates appear to have declined rapidly during the Barremian (Core 307-6R contains only zeolitic claystone with chert), probably as a combined effect of subsidence below the CCD and drift out of the equatorial highproductivity zone. The disappearance of carbonate at Sites 304 and $303 \mathrm{~A}$ higher on the ridge during the same period suggests that a regional rise in $\mathrm{CCD}$ occurred.

The recovered lithologic fragments are inadequate to determine if the sediments display cyclicity.

\section{Sites 305 and 306 (Shatsky Rise)-Berriasian through Aptian Cherts and Siliceous Limestones}

Sites 305 and 306 were drilled on the southern end of Shatsky Rise. This volcanic plateau is estimated to have formed near sea level, but drilling did not penetrate the oldest sediments. Despite the poor recovery, Matter et al. (1975) recognized two Lower Cretaceous facies: a chert-bearing nannofossil chalk of Berriasian through earliest Barremian age (Cores 306-42R to -18R) and a calcareous porcellanite and chert-dominated radiolarian limestone of Barremian through Aptian age (Cores 306-17R to approximately -7R, and 305$68 \mathrm{R}$ to about $-55 \mathrm{R})$. The petrology of the cherts and porcellanites in these facies has been studied by Keene (1975).

The lower carbonate-rich facies formed at estimated paleolatitudes of $8^{\circ}-2^{\circ} \mathrm{N}$ at depths of about $1000-1500 \mathrm{~m}$ (Table 7), and has a sedimentation rate (at Site 306) of approximately $10 \mathrm{~m} / \mathrm{m} . \mathrm{y}$. The tan to light-brownish gray, radiolarian-rich $(20 \%-40 \%)$ chalk has bioturbation disrupting vague laminations and contains greenish reduction mottles. Radiolarians are infilled by calcite spar, microspar, or silica. Porcellanite nodules are replacements of a micritic limestone. Radiolarian and clay abundances within the chalk vary vertically. Relatively clay-rich intervals also contain the lowest abundance of radiolarians (less than 10\%) as dissolved tests or infilled molds. There is approximately $2 \%$ FeMn-oxide present as coarse-silt-sized particles and stain. Carbonate analyses indicate about $85 \%-95 \% \mathrm{CaCO}_{3}$ in the chalks and $25 \%-50 \% \mathrm{CaCO}_{3}$ in the porcellanites (Bode, 1975 ; Keene, 1975). We estimate the bulk composition as $15 \%$ biogenic silica, $75 \%$ carbonate, and $8 \%$ clay.

The upper silica-rich facies formed at an equatorial paleolatitude and water depths of approximately $1500 \mathrm{~m}$ (Table 7). Sedimentation 
rate at Site 306 is estimated as $12-15 \mathrm{~m} / \mathrm{m}$.y. The dominant lithologies consist of radiolarian-rich $(15 \%-30 \%)$ micrite to radiolarian chert. The light-tan siliceous limestones are bioturbation-homogenized with faint banding and gray chert or porcellanite nodules. Carbonate analyses average from $20 \%$ (Site 305 ) to $45 \%$ (Site 306) (Bode, 1975 ), and the calcareous-rich porcellanites are about $50 \% \mathrm{CaCO}_{3}$ (Keene, 1975). About a third of the radiolarians are silica- or calcitefilled molds; the rest are partially replaced ghosts. In some cases, the silica nodules enclose calcite-spar-filled molds of former radiolarians, indicating that $\mathrm{CaCO}_{3}$ replacement by silica during chert nodule growth caused local calcite spar precipitation followed by incorporation of the less-soluble calcite-spar-filled radiolarian molds into the growing nodule (see discussion of "carbonate-replacement chert" in Behl and Smith, this volume). Some clay seams were observed within microspar-recrystallized bands. FeMn-oxides $(1 \%-2 \%)$ are mainly present as black, fine-silt-sized, dispersed particles. We estimate the bulk composition as $55 \%$ biogenic silica, $40 \%$ carbonate, and $5 \%$ clay.

Silica accumulation rates were approximately 8 times as rapid under the Barremian equator than Berriasian-Valanginian accumulation slightly north of the equator, with a maximum of approximately $1700 \mathrm{~g} / \mathrm{cm}^{2} / \mathrm{m}$.y. (Table 7). Carbonate accumulation rates decreased by $30 \%$ during the approach to the equator, but were always over $1000 \mathrm{~g} / \mathrm{cm}^{2} / \mathrm{m}$.y.

\section{Site 167 (Magellan Rise)_Late Berriasian through Barremian Siliceous Limestones}

Age and Paleolatitude. Site 167 is located on the Magellan Rise near the intersection of the Hawaiian and Phoenix magnetic lineations. The basal age for Site 167 was originally reported as Berriasianlate Tithonian (Shipboard Scientific Party, 1973a). However, the reported frequent presence of nannofossil Rucinolithus wisei from Core $82 R$ to the base of Core 93R, one core above the basalt (Roth, 1973), indicates a late Berriasian-early Valanginian age, based on the restriction of this form in the Atlantic to above magnetic chron M16n (Bralower et al., 1989). The simultaneous occurrence of nannofossil Polycostella beckmannii, which has an upper limit of late Tithonian in Atlantic-Tethys (Bralower et al., 1989), implies either that there is mixing of Tithonian and of late Berriasian taxa, or that the Pacific ranges are different than the Atlantic ranges. Magnetic anomalies M11 to M17 of the Phoenix set appear to intersect the Magellan Rise, therefore a basal age of M16, or latest Berriasian, seems probable. The basaltic basement at Site 167 is estimated to have formed at a water depth of about $700 \mathrm{~m}$ and at a paleolatitude of $10^{\circ} \mathrm{S}$ (Table 5). During the Early Cretaceous, the site drifted progressively farther from the equator, reaching $18^{\circ} \mathrm{S}$ during the early Aptian.

Lithology and Cyclicity. The basal cores (Cores 167-94R and $-93 R)$ of radiolarian-rich $(20 \%-25 \%)$ micritic limestone are reddish to brownish-olive in color. The downward increase in FeMn-oxide staining and volcanic detritus in the basal cores suggest that the hole terminated in proximity to the underlying volcanic crust. Approximately a third of the radiolarians are present as calcite spar- or microspar-filled molds; the rest are partial microspar-replaced ghosts. Porcellanite is present in minor amounts, and clay may comprise up to $10 \%$ of the basal sediments.

The overlying Valanginian to Barremian section is white to light brownish-gray, radiolarian-bearing $(5 \%-15 \%)$ micritic limestone. All sediments show moderate to intense bioturbation. Reddish to gray concretions of chert or calcareous porcellanite comprise less than $5 \%$ of the sediment. The diagenesis of silica at Site 167 was extensively studied by Lancelot (1973), who concluded that quartz chert nodule formation is restricted to carbonate facies, whereas porcellanite (opal-CT cemented siliceous sediment) forms in clay-rich sediments. The diagenesis of the host limestones and preservation of microfossils at Site 167 is summarized by Schlanger et al. (1973), who noted that nannofossil abundance appears to remain fairly constant throughout the Lower Cretaceous, whereas preserved radiolarians are quite variable in abundance from sample to sample. Radiolarians are present as calcite-spar-filled molds and as microspar ghosts. The average sedimentation rate for the late Berriasian to middle Barremian (Cores 94R through 70R) accumulation of 230 meters of siliceous limestones is $14 \mathrm{~m} / \mathrm{m}$.y.

Grayish to greenish-brown, clay-rich bands, averaging about 5$10 \mathrm{~cm}$ wide, occur at about 20 -cm intervals. These clay concentrations occur as diffuse zones of anastomosing clay-seams in a bioturbated matrix or as distinct clay seams. Clay-rich zones have a much lower abundance of radiolarians and do not contain chert nodules. Cotillon $(1984,1987)$ suggested that these clay-rich/-poor intervals at Site 167 represent Milankovitch cycles similar to those observed in the Atlantic and in Southern France. If a 20,000 yr precession frequency is assumed for the average $20-\mathrm{cm}$ spacing of the clay enrichments, then the corresponding sedimentation rate would be $10 \mathrm{~m} / \mathrm{m}$.y., which is within the constraints of the biostratigraphy and magnetostratigraphy. We will assume an average sedimentation rate of $10 \mathrm{~m} / \mathrm{m}$.y. for the Valanginian through Barremian for the purposes of mass accumulation rates.

Latest Barremian polarity Zone M1 is reported to begin in Core 167-69R, Section 2, and the earliest Aptian polarity Zone M0 in Core 67R, Section 1 (Tarduno et al., 1989); implying that this $3 \mathrm{~m} . \mathrm{y}$. interval has an average sedimentation rate of approximately $7 \mathrm{~m} / \mathrm{m}$.y. Alternatively, foraminifer identifications and contorted bedding suggest that Cores 167R-68 through - 65 may contain intervals of largescale sliding and associated missing or repeated sections; therefore the sedimentation rate is uncertain (Tarduno et al., 1989; Sliter, 1989). These early Aptian sediments of Core 67R through lower Core 65R contain an abundance of dark greenish-gray, zeolite- and glass-rich, volcanic tuff. Sliter (1989) has suggested that the lamination of the tuffs of Core 66 may also indicate low-oxygen conditions.

Mass Accumulation Rates. Carbonate contents for the Valanginian through Barremian range from $95 \%-31 \%$, averaging about $90 \%$ for the light grayish limestone and about $50 \%$ for clay-rich intervals (Bode, 1973). Incorporating the thin-section and core observations, bulk composition of the Site 167 sediments is estimated as $80 \% \mathrm{CaCO}_{3}, 15 \%$ clay, and $5 \%$ biogenic silica. The accumulation rate of carbonate is approximately $1500 \mathrm{~g} / \mathrm{cm}^{2} / \mathrm{m}$.y., whereas biogenic silica is approximately $110 \mathrm{~g} / \mathrm{cm}^{2} / \mathrm{m}$.y., the lowest of any $\mathrm{Pa}-$ cific site. The low accumulation rate of silica is probably due to the position of Site 167 at $13^{\circ}-15^{\circ}$ south of the equator. Fluctuations in carbonate productivity and preservation or in eolian input of clay were probably the cause of the varying clay abundances.

\section{Sites 304 and 303A (M9 and M4, Hawaiian Lineations)- Valanginian through Barremian Chert and Calcareous Clay}

Sites 304 and 303A formed on oceanic crust of early Hauterivian and early Barremian age, respectively. The Hauterivian-Barremian sediments of these sites are estimated to have been deposited at water depths of $2700-3500 \mathrm{~m}$ and at paleolatitudes of $7^{\circ}-9^{\circ} \mathrm{N}$.

Both sites have an upward succession of two to three basal cores above the volcanic basement which containing chert-bearing calcareous clay, followed by radiolarian-chert-rich zeolitic claystone (Shipboard Scientific Party, 1975b). This change from calcareous clay to noncalcareous claystone was interpreted as passage of the site from above to below the CCD. A CCD depth of approximately $3000-3300 \mathrm{~m}$ is implied for this latitude. However, it is probable that a regional rise in $\mathrm{CCD}$ during the Barremian, not subsidence of the sites, is the main factor.

At Site 304 , the lower brown nannofossil ooze contains brown calcareous porcellanite of metalliferous (15\%-20\% FeMn-oxide) radiolarian-rich $(20 \%)$ silicified chalk (Sample 304-12R-1, 124$126 \mathrm{~cm}$ ). The overlying brown zeolitic claystone also has porcellanite (radiolarian-rich $(20 \%-25 \%)$ silicified claystone) with $3 \%-7 \%$ FeMn-oxides and $15 \%$ fine-silt-sized mica.

At Site 303A, the lowest sediment is dark brown, bioturbated, metalliferous (10\% black FeMn-oxide), phosphate-rich(?) clayey nannofossil chalk with calcispheres, foraminifers, and shell fragments, but contains no radiolarians (Sample 303A-8R-1, 145- 
$146 \mathrm{~cm}$ ). This is overlain by dark brown, bioturbated, nannofossil claystone with brown chert composed of metalliferous clayey radiolarite $(40 \%-50 \%$ radiolarians) (Sample 303A-7R-1, 140-142 cm). The upper Barremian consists of bioturbated dark brown zeolitic claystone with yellowish-brown porcellanite of silicified radiolarianrich $(20 \%-25 \%)$ claystone.

Sedimentation rates at both sites are similar, averaging about $6 \mathrm{~m} / \mathrm{m}$.y. until the early Aptian. Based upon core and thin-section observations, the bulk composition for the calcareous claystone unit for both sites is estimated as $10 \% \mathrm{Fe}_{2} \mathrm{O}_{3}, 20 \%$ biogenic silica, $30 \%$ carbonate, and $40 \%$ clay. The overlying zeolitic claystone composition is estimated as $8 \% \mathrm{Fe}_{2} \mathrm{O}_{3}, 20 \%$ biogenic silica, and $70 \%$ clay and zeolites. The implied mass accumulation rate for biogenic silica is approximately $200 \mathrm{~g} / \mathrm{cm}^{2} / \mathrm{m}$.y., which is similar to the accumulation rates for both Site 307 and the Shatsky Rise (Site 306) when they were at a similar $5^{\circ}-9^{\circ} \mathrm{N}$ paleolatitude (Table 7).

\section{Site 463 (Mid-Pacific Mountains)_Barremian Siliceous Limestone}

The oldest recovered sediments at Site 463 were deposited about $11^{\circ}$ south of the equator in water depths estimated as approximately $500 \mathrm{~m}$ (Table 5). The site drifted to $14^{\circ} \mathrm{S}$ in the early Aptian, then began to drift northward. Paleomagnetism of sediments at Site 463 is consistent with these paleolatitudes (Sayre, 1981; Winterer and Metzler, 1984).

Integration of Site 463 magnetic stratigraphy (Sayre, 1981; Tarduno et al., 1989) and sedimentology (Shipboard Scientific Party, 1981a) allows precise determination of average sedimentation rates. Prior to the influx of volcanic ash above magnetic polarity Zone M0 of the early Aptian (Core 463-72R), approximately $190 \mathrm{~m}$ of siliceous limestone and redeposited shallow-water carbonates accumulated during the late Barremian between $\mathrm{M} 3$ and M0, implying an average sedimentation rate of approximately 20 to $25 \mathrm{~m} / \mathrm{m}$.y. During the late Barremian, a volcanic island and atoll near Site 463 was the source for numerous redeposited beds containing oolites, stromatolites, large mollusks, and echinoderms. Spores and pollen grains in these redeposited beds indicate that the island was vegetated (G. Ogg, this volume). The unsorted character of these beds suggest transport by debris flows (Shipboard Scientific Party, 1981a). These redeposition events are rarer above magnetic polarity Zone M1 (Cores 463-78R and $-77 R$ ). Approximately half of the Barremian strata are redeposited beds, therefore the sedimentation rate of the pelagic siliceous limestone component is estimated as approximately $10 \mathrm{~m} / \mathrm{m}$.y.

The pelagic sedimentation consists mainly of white, bioturbated, radiolarian-rich micritic limestone with chert-rich and clay-rich intervals. The pelagic white limestone alternates at $10-30-\mathrm{cm}$ spacing with zones containing abundant greenish to grayish clay wisps and anastomosing clay seams. Cyclicity is more pronounced when the overall clay content of the pelagic limestone increases in the latest Barremian (Core 463-83R and above). Clay-rich intervals appear to have less bioturbation than adjacent limestone intervals. Burrows from the clay-rich interval extending downward into the underlying limestone are also infilled with clayrich sediment, implying that the pelagic sediment had primary alternations of clay-rich and carbonate-rich. As clay content increases, the chert/porcellanite content decreases, suggesting inhibition of silification by the presence of clay and/or decrease in radiolarian abundance. Calcareous porcellanite is approximately twice as abundant as chert, and together comprise approximately $10 \%-15 \%$ of the pelagic sediment.

The clay-rich portion of a typical Barremian cycle consists of nannofossil micrite/microspar limestone which is radiolarian-rich (4\%-30\%, averaging $10 \%)$ and clay-rich (15\%-20\%, as estimated from shipboard carbonate analyses). Radiolarians are mainly calcite-spar-replaced and -filled. These calcified radiolarian-molds have higher concentrations in the clay-rich microspar zones. Some of this enrichment of radiolarians in clay-rich zones may be as a diagenetic residual during preferential dissolution of the fine-grained nannofossil component.
The limestone portion of a cycle consists of radiolarian-biomicrite limestone. Radiolarians comprise up to $50 \%$ (packed radiolarite). In siliceous limestones, commonly half of the radiolarians are filled by microcrystalline quartz or radial-fibrous chalcedony; the other half have partial infilling by calcite-microspar. The carbonate portion of the limestone consists entirely of micrite, with only rare calcareous microfossils.

These clay-rich/-poor alternations are similar to the cycles of Site 167. The average spacing of $20 \mathrm{~cm}$ for the Barremian cycles, where not diluted by redeposited beds or ash input, combined with the estimated $10 \mathrm{~m} / \mathrm{m}$.y. rate of pelagic sedimentation, indicates a possible cyclicity of $20,000 \mathrm{yr}$, identical to the cycle periodicity observed at Site 167. Variations in nannofossil and radiolarian productivity were probably the cause for these cycles, although clay input may also have fluctuated.

We estimate the bulk composition of the Barremian pelagic sedimentation to be approximately $15 \%$ biogenic silica (combined chert abundance and average proportion of silica-infilled radiolarians), $10 \%$ clay, and $70 \%$ carbonate. The implied relatively high mass accumulation rates of biogenic silica and carbonate $\left(300 \mathrm{~g} / \mathrm{cm}^{2} / \mathrm{m}\right.$.y. and $1400 \mathrm{~g} / \mathrm{cm}^{2} / \mathrm{m}$.y., respectively) for a site located $11^{\circ}$ from the equator may be partially due to local upwelling and enhanced fertility associated with oceanic circulation around the adjacent emergent seamounts.

The uppermost Barremian-basal Aptian, a 30-m interval from Core 463-74R through magnetic polarity Zone M0r in the middle and upper Core 463-72R, displays an upward increase in greenish coloration and reduction in radiolarian and chert content. Clay-rich layers, $2-5 \mathrm{~cm}$ thick and containing some volcanic glass, have $30-\mathrm{cm}$ average spacing. Volcanic ash dominates dark-gray, mottled, siliceous limestone of the overlying $20 \mathrm{~m}$ of lower Aptian (Cores 463-71R and $-70 \mathrm{R})$ and is interbedded with several laminated layers, containing up to $7.5 \%$ organic carbon. These organic-rich layers have sharp lower boundaries and gradational upper transitions, contain a higher proportion of marine-derived organic-carbon material as total organic carbon content increases, and have been interpreted to reflect a periodic expansion or intensification of the mid-water oxygen minimum (Dean, 1981; Dean et al., 1981; Mélières et al., 1981; Timofeev and Bogolyubova, 1981; Thiede et al., 1982). The paleodepth of Site 463 during early Aptian is estimated to be between $500 \mathrm{~m}$ and $1000 \mathrm{~m}$ (Table 5). Typical alternations of white siliceous limestone and clay-rich zones resume for another $100 \mathrm{~m}$ throughout the rest of the Aptian and into the early Albian.

\section{Site 460 (Mariana Trench)—Lower Cretaceous Calpionellid- bearing Limestone}

Site 460 , located in the inner wall of the Mariana Trench, recovered rare millimeter-sized fragments of micritic limestone within clasts of volcaniclastic sandstone, which has been redeposited in an upper Eocene-lower Oligocene conglomerate (Shipboard Scientific Party, 1982). In one thin-section (Sample 460-5R-1, 30-32), the micrite limestone lithic-grains had bioclast forms, which were interpreted from photographs by Azéma and Blanchet (1982) as Calpionella alpina calpionellids, implying a possible late Tithonian to Berriasian age. We examined other thin sections, but the circular "calpionellid" forms are rather ambiguous. This is the only reported possible occurrence of calpionellid-bearing micrite in the Pacific, but the setting of this rare facies is unknown.

Dredged fragments of middle to late Valanginian radiolarian cherts from the outer Mariana forearc are interpreted to be sediments associated with accreted oceanic crust (Johnson et al., 1991).

Site 596 (Southwest Pacific)-Lower Cretaceous and ?Late Jurassic Metalliferous Claystone

Site 596, drilled east of the Tonga-Kermadec Trench $\left(23.9^{\circ} \mathrm{S}\right.$, $\left.194.4^{\circ} \mathrm{E}\right)$, recovered a condensed section of pre-Late Cretaceous 
metalliferous clay overlying basaltic crust (Menard, Natland, Jordan, Orcutt, et al., 1987). The basement age is uncertain, but the associated magnetic anomaly may be M29, hence early Oxfordian, on a piece of Farallon Plate attached to the Pacific Plate during a possible Kimmeridgian-age ridge jump (Menard, pers. comm., 1986; however, Larson, pers. comm., 1992, considers the magnetic anomaly interpretations to be erroneous). The lowermost $2 \mathrm{~m}$ of undated sediments consist of reddish-black metalliferous clay with approximately $75 \%$ "RSO" reddish semi-opaque particles, 5\%-10\% opaque micronodules, and rare fish bones in a zeolite-bearing clay, with thin interbeds of white clay interpreted to be former volcanic ash. (Shipboard Scientific Party, 1987). The overlying $30 \mathrm{~m}$ of pre-Late to Late Cretaceous age is dusky red metalliferous clay with an upward increase in zeolite, a decrease in RSOs and micronodules, and the appearance of porcellanite and chert. The decreasing metalliferous component probably reflects increasing distance from active spreading ridges. Interbedded in these Early Cretaceous and ?Jurassic claystones are thin stringers of reddish yellow to white clay, interpreted to be altered volcanic ash.

The Early Cretaceous paleolatitudes for this site, if it was attached to the Pacific crust, are projected from Table 5 to have been between $45^{\circ} \mathrm{S}$ (Tithonian) to $60^{\circ} \mathrm{S}$ (Aptian). The volcanic basement, if Oxfordian in age, is projected to be approximately $50^{\circ} \mathrm{S}$. Paleomagnetic measurements on the basalts yield a paleolatitude of approximately $63^{\circ} \mathrm{S}$ and on the lower unconsolidated sediments yield approximately $45^{\circ} \mathrm{S}$ (Montgomery and Johnson, 1987). Therefore, Pacific pelagic sedimentation in mid-latitudes during the Early Cretaceous and possibly Late Jurassic consisted entirely of condensed accumulation of metalliferous clay with rare volcanic ash horizons. Radiolarians in mid-latitudes were either absent or underwent dissolution prior to the Late Cretaceous.

\section{INTERPRETATION OF SEDIMENTATION HISTORY}

The array of ODP and DSDP sites provide a record of the sedimentation processes in the tropical Pacific from the latest Bathonian through Aptian. The pre-Tithonian is known only from Site 801, but is similar in many aspects to oceanic Upper Jurassic radiolarite deposits accreted to Pacific margins. The Early Cretaceous is constrained by several sites at varying paleolatitudes and paleodepths. The paleoceanographic record is partially obscured by diagenetic alteration and redistribution of minerals, but the main features of mass accumulation rates and cyclicity of major components, bottom water conditions, and processes of lithification can be interpreted.

\section{Callovian Metalliferous Radiolarites of Site 801}

\section{Oxygenated Bottom Waters}

The Callovian clayey radiolarites at Site 801 are red, grading to yellowish or brownish red. White mottles cut across the internal layering of the radiolarite beds and blocks, and are interpreted as post-burial reduction zones. After correction for the varying dips, the primary magnetization carried by hematite within these blocks of radiolarite yield consistent inclinations (B. Wallick, pers. comm., 1991). The mottling and the hematite magnetization imply that oxidation of the sediments occurred at the surface, prior to localized decay of buried organics or to the slumping of the sediments. The abundance of Fe staining of matrix and coatings on some radiolarians indicates that Fe mobility and oxidation may have preceded silica mobility. Bioturbation is locally common, although most of the upper Callovian strata and some of the consolidated blocks within underlying slump deposits retain layering at the centimeter scale. The early oxidation of iron in the sediments, lack of any organic matter, and presence of bottom life indicate that oxygenated bottom waters persisted throughout the Callovian on this near-spreading ridge setting.

\section{Biological Productivity and Cyclicity}

\section{Mass Accumulation Rate of Biogenic Silica}

Siliceous tests of radiolarians are the most important component of the metalliferous clayey radiolarites of Site 801, comprising approximately $30 \%-40 \%$ of the bulk sediment in the form of silica-filled molds or partially preserved ghosts. The average silica content of the Callovian strata is $62 \%$. If half of the $\mathrm{Fe}$ ions and all of the $\mathrm{Al}$ are assumed to be present as $\mathrm{Fe}$-rich smectite, then the equivalent amount of silica incorporated in these smectite clays is approximately $15 \%$ of the total sediment. The computed apportionment of silica in clay implies that $50 \%$ of the sediment is in the form of "non-clay silica," mainly of biogenic silica origin (Table 7). The accumulation rate of this biogenic silica, assuming the $2 \mathrm{~m} / \mathrm{m}$.y. low-estimate for Callovian sedimentation, is $200 \mathrm{~g} / \mathrm{cm}^{2} / \mathrm{m}$.y. This is at the high end of the modern $100-200 \mathrm{~g} / \mathrm{cm}^{2} / \mathrm{m}$.y. accumulation rate of opal in the eastern equatorial Pacific (Lyle et al., 1988), perhaps partially due to the relatively thinner and lighter skeletons of late Cenozoic radiolarians and associated increased susceptibility to dissolution on the seafloor (Moore, 1969; Hurd and Theyer, 1975; Takahashi and Honjo, 1983; A. Matsuoka, pers. comm., 1991).

\section{Alternations of Radiolarite and Claystone}

The accumulation rate of radiolarians fluctuated significantly from the mean, producing layers of packed radiolarians interbedded with radiolarian-poor claystones. This layering is well preserved in the upper Callovian sediments due to the lack of significant bioturbation. The underlying lower and middle Callovian record is distorted by slumping, but the blocks also display similar oscillations of radiolarian enrichment.

Discrete layers of radiolarian concentrations interbedded within radiolarian-poor claystone are observed in various pelagic deposits: Callovian in Pacific Site 801, Berriasian-Valanginian in Pacific Site 800, Callovian in western Atlantic Site 534 (Shipboard Scientific Party, 1983; Ogg et al., 1983), Cenomanian in eastern Atlantic Sites 386 and 387 (McCave, 1979; Kälin et al., 1979), and in Callovian-Oxfordian silicified radiolarites in Ligurian ophiolite sections in Italy (Folk and McBride, 1978; Kälin et al., 1979; Barrett, 1981a, 1982; and field observations by us). These discrete radiolarian enrichment bands are a different facies than the relatively clay-poor and rhythmic-bedded "ribbon" radiolarian cherts. However, discrete radiolarian-rich layers commonly occur in proximity to ribbon radiolarites and, in some cases, may indicate a related origin of formation.

There are several hypotheses for the origin of alternating discrete layers of clay and radiolarite observed in the oceanic cores and of ribbon radiolarian cherts. The petrography and sedimentary structures vary among deposits, and it is probable that different processes or combinations of processes are involved (Jenkyns and Winterer, 1982; Baltuck, 1983). Differential silica dissolution/precipitation between clay-enriched and-depleted layers would enhance the original compositional differences, regardless of the initial origin of the concentrations. Indeed, it is possible that slight differences in initial radiolarian to clay ratios may have been accentuated into distinct chert and claystone horizons through diagenetic segregation of silica (e.g., Karl, 1984; Brueckner et al., 1987). The origins of radiolarianrich bands and for even-bedded radiolarian cherts include the following possibilities:

1. Episodic blooms or periodic high productivity of radiolarians. Mass accumulation rates of biogenic opal during the Pleistocene varies in association with Milankovitch climatic-oceanographic cycles, which affected surface productivity (e.g., Rea et al., 1991). It is probable that similar cycles of oceanic productivity and associated flux of radiolarians to the sediments have been active throughout the 
Mesozoic. Some rhythmic-bedded radiolarian chert deposits have been interpreted to be partially formed by episodic flux of radiolarians (e.g., McBride and Folk, 1979; McCave, 1979; Jenkyns and Winterer, 1982; De Wever, 1987; Ruiz-Ortiz et al., 1989)

2. Redeposition pulses of radiolarian-rich sediment as turbidites from adjacent margins or local topographic highs, or as deposits from bottom currents. Several of the Tethyan radiolarites display sedimentary structures indicative of redeposition, such as grading and mudstone chips, or regional patterns suggesting redeposition into basinal settings (e.g., Nisbet and Price, 1974; Folk and McBride, 1978; Kälin et al., 1979; Barrett, 1981a, 1982; Baumgartner, 1987). This model has also been applied to some radiolarian chert successions accreted to Pacific margins (e.g., Hein and Karl, 1983; Hein et al., 1983; Gursky and Schmidt-Effing, 1983; Karl, 1984). In many cases, the source region of the postulated siliceous turbidites has not been identified, nor is the absence of significant radiolarians within the host claystone explained.

3. Pulses of clay input from variable eolian flux or as distal turbidity currents. Shale partings in some Mesozoic rhythmic bedded chert formations in Japan have been interpreted from geochemical comparisons to be distal turbidites (Matsumoto and Iijima, 1983; lijima et al., 1985).

4. Current winnowing and concentration of radiolarian tests. Radiolarian tests have a very low density owing to their delicate framework skeleton, and winnowing is facilitated by the presence of spines that inhibit adhesion to sediment; therefore, suspension and redistribution by near-bottom currents is probably more common than concentration as a turbidite density current (P. Baumgartner, pers. comm., 1989). In situ winnowing of radiolarian tests is possible if the tests become filled with clay or undergo partial overgrowths. Some siliceous layers in Jurassic basinal sediments are composed of winnowed sponge spicules, rather than concentrated radiolarians (P. Baumgartner, pers. comm., 1989).

5. Variable dissolution of silica in the uppermost sediment prior to burial. The preservation of radiolarian tests is affected by the Eh and $\mathrm{pH}$ of the interstitial waters (e.g., Johnson, 1975; Kastner et al., 1977; Riech and von Rad, 1979; Kastner and Gieskes, 1983), and varies among different radiolarian taxa (Takahashi, 1987). Therefore, enhancement of silica preservation could result from several factors, including the presence of reducing organic material or an increase in the $\mathrm{CO}_{2}$ content of bottom waters (e.g., De Wever, 1982).

The origin of the interlayed radiolarite and claystone deposits in the Callovian at Site 801 cannot be deduced from the available sedimentary and chemical data, but some of the possibilities can be rejected. The presence of upper and lower transition zones between claystone and radiolarite layers, even if only a couple of millimeters thick, argue against turbidite redeposition of the radiolarites or of the clay (Fig. 6B). Source regions for an influx of concentrated radiolarian turbidites into a claystone basin is not consistent with the subdued Jurassic topography. Current winnowing would produce sharp contacts and lenticular concentrations of radiolarians, which is not observed. Transport by currents would also produce flasers, starved ripples, or discrete laminae, and appears to have played only a minor role in sediment deposition on this oxygenated Callovian sea bottom.

Variable flux of radiolarians and/or clay, with primary differences in composition enhanced by surface dissolution and burial diagenesis of siliceous tests, is the mechanism most consistent with our observations. In the overlying Upper Jurassic, the silica content of strata fluctuates in harmony with Milankovitch climate cycles of eccentricity, presumably as a result of periodic pulses of radiolarian influx (Molinie and Ogg, this volume); likewise, the Callovian may display similar cycles of productivity. Orbital-precession cycles, modulated by eccentricity, should have been the dominant influence on climate within the equatorial regions of the Mesozoic world (Oglesby and Park, 1989). Relatively abrupt changes in tropical upwelling may have occurred in response to Milankovitch fluctuations, especially if the surface current gyres to the north and south of the equator were not well established due to the continuation of the Pacific into the eastern Tethys. The flux of radiolarians to the seafloor is a good measure of seasonal surface productivity, although the preserved assemblages will be skewed by variable dissolution (e.g., Takahashi, 1987). Milankovitch cyclicity in radiolarian influx and associated silicification is observed in the overlying Upper Jurassic and Lower Cretaceous radiolarites (Molinie and Ogg, this volume); therefore, it is probable that similar climate-induced cyclicity of productivity was also present during the Callovian. If these thin-bedded radiolariteclaystone cycles, averaging $4 \mathrm{~cm}$ in thickness, represent precessioninduced Milankovitch climatic cycles having 20 k.y. periodicity, then the corresponding sedimentation rate for the upper Callovian is $2 \mathrm{~m} / \mathrm{m}$.y., and this 5.4-m interval represents $2.7 \mathrm{~m}$.y.

If these periodic variations in radiolarian influx are caused by climatic-oceanographic cycles, then it is possible that other pelagic radiolarites would have experienced similar variations in radiolarian abundance. In intervals lacking bioturbation, this original signal might have been preserved. Such a radiolarian-productivity periodicity is one of the several models for the formation of ribbon-bedding in some radiolarian chert deposits (e.g., Jenkyns and Winterer, 1982). However, intractable problems of diagenetic overprinting and lack of a detailed time scale preclude demonstration of Milankovitch periodicity within most ribbon-bedded radiolarite deposits.

\section{Metalliferous and Clay Components}

\section{Iron Enrichment}

The Callovian sediments (samples from Cores 801B-36R and $-33 \mathrm{R})$ have an average $\mathrm{Al} /(\mathrm{Al}+\mathrm{Fe}+\mathrm{Mn})$ of 0.42 , with $\mathrm{Fe}$ concentrations generally equal to $\mathrm{Al}$. The average $\mathrm{Fe}: \mathrm{Al}: \mathrm{Mn}$ weight $\%$ of Callovian strata of 100:55:1 represents less than half the Fe-enrichment observed in the underlying interpillow sediments, which have ratios in the range of 100:20:1.

Significant iron enrichment of sediments $(\mathrm{Al} /(\mathrm{Al}+\mathrm{Fe}+\mathrm{Mn})$ less than 0.40 ) occur up to $1000 \mathrm{~km}$ from the fast-spreading East Pacific Rise (Boström and Peterson, 1969; Boström et al., 1969). Within 50 km

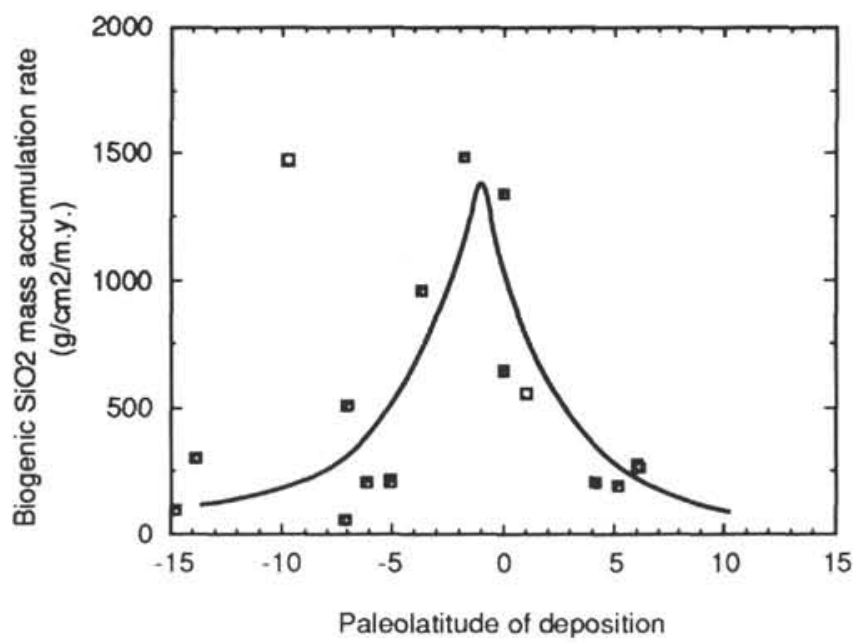

Figure 11. Biogenic silica accumulation rates with paleolatitude for Middle Jurassic through Early Cretaceous radiolarites and radiolarian-rich sediments. Accumulation rates include Sites 167, 303/304, 306, 307, 463, and 800 (Table 7). The anomalously Valanginian of Site 801 and the Triassic radiolarites of Japan are shown by open squares. Biogenic accumulation is greatest within about $5^{\circ}$ of the paleoequator, and peaks at about $1^{\circ} \mathrm{S}$. Paleolatitudes from skewness models of magnetic lineations (Fig. 3) would shift this curve about $6^{\circ}$ to the south. 
of the ridge, hydrothermal vents can contribute colloidal Fe and $\mathrm{Mn}$, which precipitates to the seafloor in more oxic environments. Fe and Mn accumulate over the East Pacific Rise nearly 10 times faster than in sediments away from the ridge crest ( $35 \mathrm{vs} .3 .1 \mathrm{~g} / \mathrm{cm}^{2} / \mathrm{m}$.y.) (Leinen and Stakes, 1979). The distribution of $\mathrm{Al}$-poor sediments on ridges correlates well with the rates of seafloor spreading (Boström et al., 1969), and the accumulation rates of Fe in East Pacific Rise sediments correlate closely with times of major change in spreading rate or direction along the rise crest (Leinen and Stakes, 1979).

Site 801 , which has a basement age of approximately $170 \mathrm{Ma}$, is $800 \mathrm{~km}$ from magnetic anomaly M25, which has an age of $157 \mathrm{Ma}$ (Kimmeridgian/Oxfordian boundary). Therefore, the Pigafetta Basin formed during the Callovian-Oxfordian at a relatively fast, spreading half-rate, estimated as $60-70 \mathrm{~km} / \mathrm{m}$.y. This spreading rate is similar to that of the present East Pacific Rise. Significant enrichment in iron and manganese would therefore be expected through the CallovianOxfordian. An average Callovian sedimentation rate of $2 \mathrm{~m} / \mathrm{m} . \mathrm{y}$. implies that the accumulation rate of elemental $\mathrm{Fe}(5 \% \mathrm{Fe}$ in sediment having $2 \mathrm{~g} / \mathrm{cm}^{3}$ wet bulk density) is $15 \mathrm{~g} / \mathrm{cm}^{2} / \mathrm{m}$.y., consistent with the rate expected for this near-ridge location.

\section{Clay Component}

Much of the Fe-enrichment within the Callovian claystone and radiolarite is probably in the form of authigenic Fe-rich montmorillonite and other Fe-smectites. Authigenic deep-sea Fe-smectites are common near spreading centers. Smectite clays in the near-ridge-crest sediments have a range of compositions from the end-member of $\mathrm{Fe}_{2} \mathrm{Si}_{4} \mathrm{O}_{10}(\mathrm{OH})_{2}$, which is approached in nontronite formed near Galapagos hydrothermal vents, to mixed-layer smectite with $\mathrm{Fe} / \mathrm{Al}$ ratios of 3, typical of East Pacific Rise Femontmorillonite (McMurtry et al., 1983). The formation of authigenic $\mathrm{Fe}$-smectite may be from the reaction of $\mathrm{Fe}$-hydroxides, transported from ridge vents, with biogenic Si (Heath and Dymond, 1977; Aoki et al., 1974), or it may be the Fe-smectite clay, and not the Fe-hydroxide, that was transported (McMurtry et al., 1983). The source of $\mathrm{Al}$ in these smectites in ridge settings may either be as detrital ( $\mathrm{Al}$ ) montmorillonite mixing with authigenic (Fe) nontronite, or from $\mathrm{Al}$-rich volcanic detritus allowing $\mathrm{Al}$-rich nontronite to form (reviewed in Weaver, 1989).

Most $\mathrm{Al}$ in Pacific sediments, including those from the East Pacific Rise, is detrital in origin (Leinen and Stakes, 1979). Most of the Al-rich clay influx into the Tropical Pacific is carried by tradewind belts and the Equatorial Current, and the accumulation rates generally decrease westward. An observed small equatorial enrichment in $\mathrm{Al}$ and in some other metals may reflect the intensity of equatorial eolian-current transportation, perhaps coupled with biological scavenging in the associated high-productivity belt. Present-day sediments accumulating between the equator and $20^{\circ} \mathrm{N}$ are probably influenced by seasonal wind patterns, receiving clays from Asia transported by the westerlies during the spring and from North America by the tradewinds during the winter dry season (Leinen, 1989; Rea, 1990).

The average $\mathrm{Al}$ accumulation rate through the Tertiary is $1-3$ $\mathrm{g} / \mathrm{cm}^{2} / \mathrm{m} . \mathrm{y}$. in the main equatorial zone (Leinen and Stakes, 1977). Al accumulation rates typically exceed $10 \mathrm{~g} / \mathrm{cm}^{2} / \mathrm{m} . y$. at $10^{\circ} \mathrm{N}$, possibly reflecting increased terrigenous input. Total detrital influx to Paleogene pelagic clays in the Pacific is estimated at only $10-20 \mathrm{~g} / \mathrm{cm}^{2} / \mathrm{m}$.y., and accelerated by an order of magnitude in the Neogene when climate became drier and eolian erosion and transport increased (Leinen and Heath, 1981; Janecek and Rea, 1983; Rea et al., 1985; Leinen, 1989). Influx of atmospheric dust also increases during glacial periods and mirrors climatic cycles of Milankovitch periodicity (e.g., Reaetal., 1991). However, there is not a systematic relationship between the $\mathrm{Al}$ accumulation and the position of tropical Pacific sites, suggesting that bottom-current redistribution may play a role (Donnelly and Wallace,
1976). Using the $2 \mathrm{~m} / \mathrm{m}$.y. low-estimate of sedimentation rate, $\mathrm{Al}$ accumulated in the Callovian sediments of Site 801 at about $10 \mathrm{~g} / \mathrm{cm}^{2} / \mathrm{m}$.y. (Table 7), consistent with its estimated paleolatitude under the southern tradewind belt. However, the rate is comparable to that during the present-day climate, suggesting that eolian transport was enhanced by the relative dryness of the Pangea supercontinent.

Analyses of Callovian clay and radiolarite indicate an constant $\mathrm{Al} / \mathrm{K}$ ratio of 2.6 and a $\mathrm{K} / \mathrm{Mg}$ ratio of $2 . \mathrm{Ti} / \mathrm{Al}$ ratios of Callovian sediments range from $0.024-0.035$, indistinguishable from the average terrigenous clay with $\mathrm{Ti} / \mathrm{Al}$ in the range $0.027-0.036$ (Donnelly and Wallace, 1976).

\section{Manganese Depletion and Interstitial Water Conditions}

Mn has extremely low relative concentrations in these hematiterich Callovian sediments (Fe/Mn averages 100). The bright red coloration is due to hematite, without darkening by manganese-oxide. In contrast, the brown-colored, overlying radiolarites of Oxfordian and younger strata have $\mathrm{Fe} / \mathrm{Mn}$ ratios of 8 .

This extreme Mn-depletion of the Callovian strata is unusual relative to other pelagic sediments in a near-ridge setting. Metalliferous hydrothermal deposits on the East Pacific Rise generally have $\mathrm{Fe} / \mathrm{Mn}$ ratios of 3 (Dymond, 1981). Near the present equatorial East Pacific Rise, sediments typically have Fe/Mn ratios of 5-8; farther from the ridge, Fe/Mn is typically 3-5 (Leinen and Stakes, 1979). The gradient in $\mathrm{Fe} / \mathrm{Mn}$ away from the hydrothermal sources is caused by the greater solubility and sensitivity to redox conditions of Mn compared to $\mathrm{Fe}$ (Krauskopf, 1957). Average accumulation rates of $\mathrm{Mn}$ at the East Pacific Rise is approximately $5 \mathrm{~g} / \mathrm{cm}^{2} / \mathrm{m}$.y. (Leinen and Stakes, 1979). In contrast, the maximum rate of accumulation of $\mathrm{Mn}$ in these upper Callovian sediments is $0.2 \mathrm{~g} / \mathrm{cm}^{2} / \mathrm{m}$.y., assuming the faster estimated sedimentation rate of $5 \mathrm{~m} / \mathrm{m}$.y., and probably only $0.1 \mathrm{~g} / \mathrm{cm}^{2} / \mathrm{m}$.y., using the probable sedimentation rate of $2 \mathrm{~m} / \mathrm{m}$.y. (Table 7). Slowly accumulating North Pacific red clays have typical $\mathrm{Fe} / \mathrm{Mn}$ ratios of 7-15 (Goldberg and Arrhenius, 1958; Cronan, 1969; Yamamoto, 1988). Therefore, the Callovian radiolarites have a Fe content corresponding to their near-ridge setting, but a Mn content that is an order of magnitude less than similar metalliferous pelagic sediments.

The notable absence of $\mathrm{Mn}$ is either the result of post-burial migration or due to an original non-precipitation. Precipitation of Mn-oxide decreases with either decreasing Eh or decreasing $\mathrm{pH}$. In the present open ocean $\left(\mathrm{pH}=8.1, \mathrm{pO}_{2}=0.2, \mathrm{Eh}=0.4 \mathrm{~V}\right), \mathrm{Mn}^{2+}$ is oxidized and precipitates as $\mathrm{MnO}_{2}$ in nodules and crusts (Brookins, 1988; Mangini et al., 1990). Present oxygen levels in Pacific bottom water are sufficient to oxidize most organic matter; therefore, the Mn redox level is generally too deep within the sediment to allow $\mathrm{Mn}^{2+}$ migration into the water column (Froelichetal., 1979; Emerson and Hedges, 1988). During glacial stages, higher flux of organic carbon to the sediments and associated lower bottom-water oxygen levels may have resulted in the observed episodes of slower growth of Mn crusts and in increased $\mathrm{Mn}^{2+}$ levels in ocean water (Dean et al., 1989; Mangini et al., 1990). During the following transition to interglacial conditions, a pulse of $\mathrm{MnO}_{2}$ precipitation occurred when bottom-water oxygen levels increased. In a similar manner to this Pleistocene situation, one possible model for the lack of Mn within the Callovian sediments would be low-oxygen bottom-water conditions or an increased burial of organic matter, which resulted in the early reduction and migration of $\mathrm{Mn}^{2+}$ from the sediment. The observed low level of bioturbation mixing suggests low bottom-water oxidation levels, but the early formation of hematite in the sediments indicates that oxygenation levels were sufficient to form iron oxide. However, reduction mobilization of $\mathrm{Fe}$ requires a much more reducing condition than $\mathrm{Mn}$, therefore the small amounts of organic material associated with radiolarian tests and burrow detritus may have been adequate for early mobilization of $\mathrm{Mn}$.

Post-burial (diagenetic) migration from the Callovian strata of $\mathrm{Mn}^{2+}$ and perhaps other metal ions upward into Oxfordian and 
younger strata is suggested by common Mn-oxide micronodules and dendritic fracture-coatings within the overlying brownish radiolarites. A similar fractionation of $\mathrm{Mn}$ from $\mathrm{Fe}$ in metalliferous radiolarian claystones is observed in Lower Cretaceous radiolarites on oceanic crust exposed in Turkey, and has been interpreted as possible mobilization of Mn during the decay of organic matter in buried radiolarians (Robertson, 1981). Fe-rich, but Mn-depleted, mudstones occur within the Troodos Complex of southern Cyprus, and may reflect an original lowered $\mathrm{Eh}$ in a bathymetric depression which resulted in almost complete separation of Mn from Fe (Robertson, 1978). Postburial migration/precipitation of $\mathrm{Mn}$ has also been postulated to explain bands of elevated Mn-oxide associated with turbidites (Dean et al., 1989) or within Upper Cretaceous variegated claystone overlying organic-rich shales (Arthur, 1979). For our Callovian situation, this scenario would require post-burial flow of fluids upward from the basalt, sufficiently low in Eh to dissolve the Mn-oxides, but not affecting the hematite.

An alternative hypothesis is that the important factor was the $\mathrm{pH}$ of the bottom waters, rather than Eh and oxygen levels within the buried sediment. Precipitation of $\mathrm{MnO}_{2}$ would no longer occur in the present ocean if the $\mathrm{pH}$ of ocean water shifted from 8.1 to a more acidic 7.9. This minor increase in acidity would not affect hematite formation, but silica precipitation and preservation would be enhanced and carbonate dissolution would increase slightly. Two methods to lower the $\mathrm{pH}$ of bottom or interstitial waters are increased levels of dissolved $\mathrm{CO}_{2}$ or of dissolved silica. An increase of dissolved $\mathrm{CO}_{2}$ might be generated if the ocean equilibrated with an elevated atmospheric $\mathrm{CO}_{2}$ level, or if buried organic carbon underwent early oxidation in the carbonate-depleted sediment. Dissolved silica concentration in interstitial pore waters and an associated lowering of $\mathrm{pH}$ generally increases with depth in siliceous sediments, until opal-CT begins to precipitate. An early diagenetic shift in sediment $\mathrm{pH}$, by even a small amount, would result in dissolution of Mn-oxide. This slight decrease in interstitial-water $\mathrm{pH}$, either primary or during early burial, would be consistent with the high hematite concentrations within these silica-rich sediments, with the lack of preserved carbonate, and with the absence of $\mathrm{Mn}$-oxide.

Of the possible influences on interstitial-water $\mathrm{pH}$ level, the most speculative, but most interesting, is the possibility that the net $\mathrm{pH}$ of ocean water was slightly decreased due to equilibrium with an elevated atmospheric $\mathrm{CO}_{2}$ concentration. $\mathrm{Mn}^{2+}$ levels would increase in the ocean, and $\mathrm{MnO}_{2}$ precipitation would be favored mainly in environments having an Eh that was slightly higher than present ocean water, such as aerated carbonate platforms. A period of reduced deep-water $\mathrm{pH}$ from increased dissolved $\mathrm{CO}_{2}$ will enhance the dissolution of carbonate, resulting in an elevated CCD in the oceans. Slightly more acidic surface waters also favor plankton which precipitate siliceous tests over those which precipitate carbonate tests. A similar scenario of an high- $\mathrm{CO}_{2}$ pulse and associated paleoceanographic conditions has been proposed for the middle Cretaceous (Sheridan, 1983; Arthur et al., 1985).

\section{Diagenetic Processes}

\section{Inhibition of Silicification}

Why are most of these Callovian radiolarite layers unsilicified, in contrast to overlying Oxfordian-Kimmeridgian chert-rich sediments? Apparently the thin-bedded claystone and radiolarite did not have sufficient silica available for the continued silicification that is necessary for the formation of dense chert. Other than a few early-silicafilled radiolarians, the claystone layers do not have sufficient siliceous tests for chertification or to provide a significant silica source for silicification of adjacent radiolarite layers. The thin "radiolarite" layers are mainly composed of partially silicified ghosts of radiolarians; their total silica content, including Fe-smectite clays in the matrix, is only $65 \%$. Therefore, complete utilization of this silica by dissolution, migration, and precipitation would be inadequate to produce chert layers thicker than $1 \mathrm{~cm}$. The high clay content will also slow the rate of silica reprecipitation as opal-CT (Kastner et al., 1977).

\section{Dissolution of Carbonate}

Calcareous microfossils are not preserved within the Callovian sediments. Only chance preservation of a few nannofossils are present, in a basalt fissure containing calcareous claystone clasts and rare specimens of Watznaueria barnesae in Core $801 \mathrm{~B}-33 \mathrm{R}-1,58 \mathrm{~cm}$. The absence of carbonate from these near-equatorial ridge-crest sediments suggests either that the CCD was shallower than $3 \mathrm{~km}$ in the Callovian Pacific, or that carbonate dissolved during early diagenesis of the clayey radiolarites and the $\mathrm{Ca}^{2+}$ ions migrated into the water column.

\section{Late Jurassic-Early Cretaceous Facies and Paleoceanography}

\section{Bottom Water Oxygenation}

Late Jurassic through Lower Cretaceous sediments reflect oxygenated bottom waters and bioturbation mixing at all depths and latitudes on the seafloor of the central Pacific and indicate that surface productivity was equal or greater than present levels. Despite the more equable climate commonly assumed to have existed during this time interval, there is no evidence of sluggish deep water or surface ocean circulation.

All sediments containing abundant $\mathrm{Fe}$ are reddish-colored by hematite. Greenish Fe-reduction mottles within the reddish host sediment indicate that the hematite formed at or near the sediment surface, and was locally reduced after burial, perhaps adjacent to concentrations of organic matter. There is no organic carbon, including dinoflagellate cysts or sporomorphs, preserved in any pelagic sediment deposited on oceanic crust.

In contrast to the ubiquitous oxygenation of the Pacific sediments, the Atlantic pelagic carbonates have preserved Late Jurassic through Early Cretaceous organic microfossils, enabling development of a regional high-resolution dinoflagellate stratigraphy (Habib, 1983; Habib and Drugg, 1983), and display frequent intervals of laminated sedimentation with elevated organic-carbon content during the Valanginian through Aptian (e.g., Lancelot et al., 1972; Robertson and Bliefnick, 1983; Ogg et al., 1987; Huang, 1991).

A few layers preserving significant organic carbon do occur in mid-water depths $(500 \mathrm{~m}-1500 \mathrm{~m}$ ) within the Pacific during the early Aptian. At Site 463, organic-rich layers occur within volcanic-ashbearing siliceous marl, which may represent local impingement of an intensified oxygen-minimum zone (Dean et al., 1981; Thiede et al., 1982). Organic-rich layers of early Aptian age are also observed on other Pacific oceanic plateaus (Site 305 on Shatsky Rise, Site 317 on Manihiki Plateau, Calera Limestone in California) and correlate with an "oceanic anoxic event" observed in the Atlantic-Tethyan region (e.g., Schlanger and Jenkyns, 1976; Sliter, 1989; Arthur et al., 1990). In contrast to lower Aptian deposits in the Atlantic ocean, where organic-rich "black shale" facies are found at all paleodepths, the Pacific ocean sites do not display indications of low-oxygen conditions at depths below approximately $1000 \mathrm{~m}$. Some of the organiccarbon-rich layers reported from deeper Pacific sites may be rapidly buried organic-bearing strata associated with redeposition events from nearby vegetated islands or shallow-marine carbonate platforms (G. Ogg, this volume), and the strata bearing the organic-rich intervals at Site 463 appear to be within a displaced block (Sliter, 1989). Except for this early Aptian event recorded at some mid-depth sites, the Pacific waters appear to be oxygenated at all depths throughout the Jurassic and Early Cretaceous. At most sites, oxygenation of pelagic sediments continues through the Upper Cretaceous.

Bioturbation is ubiquitous in all recovered sediments. The amount and penetration of bioturbation mixing seems to have been greater at 
those sites receiving more rapid deposition of carbonate (Sites 167 and 463), perhaps due to the associated higher flux of organic material to the seafloor. Bioturbation mixing appears to have been of lesser importance during the Callovian, allowing the preservation of many of the reddish bands of radiolarite and claystone at Site 801. Radiolarites of Oxfordian and younger strata at Site 801 have a more diffuse banding and display a "woody" texture of wispy, irregular discontinuous lamination, which may be partly induced by fine-scale bioturbation and compacted burrows. Valanginian radiolarites at Site 800 have preserved more primary banding of radiolarite/claystone and display a lesser degree of bioturbation than the coeval radiolarites at Site 801. Radiolarian-rich portions of cycles at all sites display sedimentary structures suggestive of bottom current activity.

\section{Biogenic Silica vs. Paleolatitude}

Jurassic and Early Cretaceous accumulation rates at most Pacific sites averaged about $5-10 \mathrm{~m} / \mathrm{m}$.y. of biogenic siliceous/calcareous sediments (Tables 5, 7). The corresponding mass accumulation rates average $200-500 \mathrm{~g} / \mathrm{cm}^{2} / \mathrm{m}$.y. of biogenic silica and, for sites above $3500 \mathrm{~m}, 1000-1500 \mathrm{~g} / \mathrm{cm}^{2} / \mathrm{m}$.y. of $\mathrm{CaCO}_{3}$ (Table 7). In comparison, the present central equatorial Pacific has accumulation rates of 100 $200 \mathrm{~g} / \mathrm{cm}^{2} / \mathrm{m}$.y. for opal (Lyle et al., 1988) and approximately 1000 $2000 \mathrm{~g} / \mathrm{cm}^{2} / \mathrm{m}$.y. of $\mathrm{CaCO}_{3}$ (Theyer et al., 1989). Therefore, when compared to the present, the Early Cretaceous near-equatorial Pacific had equivalent or even higher rates of biogenic sedimentation, and presumably similar rates of surface productivity.

Biogenic silica accumulation during the Jurassic and Early Cretaceous depended mainly on paleolatitude (Table 7; Fig. 11). Regardless of geological age or depth of site, the accumulation rate of biogenic silica is approximately $200 \mathrm{~g} / \mathrm{cm}^{2} / \mathrm{m}$.y. between $10^{\circ}$ and $5^{\circ}$ paleolatitude and rises to an average of $1000 \mathrm{~g} / \mathrm{cm}^{2} / \mathrm{m} . y$. near the paleoequator (Fig. 11). This latitude dependence of silica accumulation is symmetric about the paleoequator, with the apparent peak occurring at about $1^{\circ} \mathrm{S}$. Some sites display anomalously high computed rates of biogenic silica accumulation (e.g., the Valanginian at Site $801,1500 \mathrm{~g} / \mathrm{cm}^{2} / \mathrm{m}$.y. at a $8^{\circ} \mathrm{S}$ paleolatitude), which could indicate a localized current depocenter or a more vigorous southern gyre, but most sites are quite consistent. This equatorial-latitude pulse of high radiolarian productivity is the Mesozoic equivalent of the equatorial "carbonate bulge" of the Cenozoic Pacific (Berger, 1973; Berger and Winterer, 1974; van Andel et al., 1975). Lancelot recognized that this silica-pulse recorded the Early Cretaceous equatorial-transit in Sites 303, 304, and 307 and could be used to deduce the motion of the Pacific Plate (Lancelot and Larson, 1975; Lancelot, 1978). Our analyses and addition of more sites quantifies the effect of this equatorial "silica bulge" as a major control on sedimentation patterns during the Late Jurassic and Cretaceous.

The average biogenic silica accumulation rate, $700 \mathrm{~g} / \mathrm{cm}^{2} / \mathrm{m}$.y. is approximately 4 times faster than opal accumulation rates in the present central equatorial Pacific (Lyle et al., 1988), but is considerably less than the average of $2000 \mathrm{~g} / \mathrm{cm}^{2} / \mathrm{m} . y$. associated with the Neogene Polar Front Zone in the sub-Antarctic (Froelich et al., 1991). The Mesozoic Pacific may have had elevated levels of equatorial biogenic silica accumulation that were compensated by lesser high-latitude deposition. Mesozoic radiolarians are also more robust than present siliceous radiolarians and diatoms (Moore, 1969; Hurd and Theyer, 1975; A. Matsuoka, pers. comm., 1991); therefore the reduced surficial dissolution may have led to greater preservation of biogenic silica.

At a given latitude, silica accumulation rates did not change with time during the Jurassic and Early Cretaceous. At $5^{\circ}-8^{\circ} \mathrm{N}$, Sites 303 , $304,306,307$, and 801 all have accumulation rates of biogenic silica of approximately $200-250 \mathrm{~g} / \mathrm{cm}^{2} / \mathrm{m}$.y., independent of their ages, which span late Callovian to late Barremian (Table 7; Fig. 11). Silica accumulation does not appear to change significantly with depth;
Site 306 was approximately $2000 \mathrm{~m}$ shallower than Site 307 . We conclude that the accumulation rate, and presumably surface productivity, of radiolarians depended mainly on proximity to equatorial latitudes during this interval. Therefore, it should be possible to use the accumulation rate of biogenic silica at other Pacific exposures to estimate the paleolatitude of formation. Accumulation rates of biogenic silica in the bedded radiolarites of the Marin Headlands (California) and of the Nicoya Complex (Costa Rica) are estimated to be about $400 \mathrm{~g} / \mathrm{cm}^{2} / \mathrm{m}$.y. (Table 7), suggesting that both of these sites were within $5^{\circ}$ of the equator during the Early Cretaceous.

\section{Carbonate Accumulation and CCD Levels}

Carbonate accumulation, unlike that of silica, was both age- and depth-dependent in the Mesozoic Pacific. Prior to the Berriasian, there was no preservation of carbonate on Pacific ridges (Sites 196, 307, $800,801)$. In contrast, the Atlantic had sedimentation of silty nannofossil marl at ridge depths during the Callovian (Shipboard Scientific Party, 1983), preservation of aragonite at depths of approximately $3800 \mathrm{~m}$ during the Kimmeridgian (Ogg et al., 1983), and continued accumulation of nannofossil limestone at all depths through the Berriasian. The rare traces of nannofossils in Bathonian and Tithonian radiolarites at Site 801 suggests that carbonate particles were falling to the seafloor, but were generally not preserved from dissolution on the sediment surface or during early diagenesis.

The oceanic depth of recorded carbonate accumulation, which may be the carbonate compensation depth, descended or was stable during the earliest Cretaceous, then rose again during the Barremian and Aptian. The earliest Cretaceous history is constrained by Sites 196 and 307 vs. Site 800 : the Berriasian CCD was between 3400 and $4000 \mathrm{~m}$, the Valanginian CCD was between 3700 and $4100 \mathrm{~m}$, and the Hauterivian CCD was between 3800 and $4300 \mathrm{~m}$. The Barremian CCD was between 3000 and $3300 \mathrm{~m}$ (Site 303A vs. Sites 304 and 307). The early Aptian CCD was shallower than $3500 \mathrm{~m}$ (Site 303A). These depths are for the $\mathrm{CCD}$ at about $5^{\circ} \mathrm{N}$. The present equatorial Pacific ocean has an average CCD of approximately $5000 \mathrm{~m}$, although it was again as shallow as $3500 \mathrm{~m}$ during the Eocene (van Andel et al., 1975).

The accumulation rate of carbonate for sites above the CCD was between 1000 and $1600 \mathrm{~g} / \mathrm{cm}^{2} / \mathrm{m}$.y. The latitudinal coverage by sites above the CCD is inadequate to document an equatorial "carbonate bulge." Oceanic crust Site 307 displays an accelerated carbonate accumulation rate during the Hauterivian when it was beneath the equator, but nearby Site 306 on the Shatsky Rise appears to have a slight drop in accumulation at the same time and latitude (Table 7).

One major control on the oceanic $\mathrm{CCD}$ is the level of dissolved $\mathrm{CO}_{2}$ in deep ocean water. The sedimentary record indicates that the Pacific maintained active deep-water circulation and bottom oxygenation of organic matter; therefore, elevation of the $\mathrm{CCD}$ due to accumulation of dissolved $\mathrm{CO}_{2}$ under stagnant conditions is not feasible. However, if these deeper water masses initially formed with a high dissolved $\mathrm{CO}_{2}$ level, perhaps arising from being in equilibrium with a significantly higher atmospheric $\mathrm{CO}_{2}$ level than present, then the increased dissolution of carbonate would be expected. Berner (1990) estimates that the Late Jurassic may have atmospheric $\mathrm{CO}_{2}$ levels at 3 times present, or $1000 \mathrm{ppm}$, dropping slightly at the end of the Tithonian and earliest Cretaceous, then rising to over 4 times present during the middle Cretaceous. While Berner's model is mainly based upon carbonate deposition patterns in the Atlantic-Tethys region, the postulated atmospheric $\mathrm{CO}_{2}$ levels are consistent with the observed Pacific carbonate deposition history. An increased level of dissolved $\mathrm{CO}_{2}$ will also shift the oceanic $\mathrm{pH}$ to slightly more acidic conditions, thereby enhancing the precipitation and preservation of silica.

With a reduction in atmospheric $\mathrm{CO}_{2}$ and corresponding lowering of the oceanic CCD, the Age of Chalk ("Creta-ceous") begins during the Berriasian in the Pacific with accumulation of radiolarian-rich 
nannofossil ooze on the shallower ridges. A widespread increase in volcanic activity during the Barremian-Aptian, especially within the Pacific, resulted in an increase in atmospheric $\mathrm{CO}_{2}$ and corresponding elevation of the oceanic $\mathrm{CCD}$, followed again by widespread deposition of organic-rich shales in the ancient Atlantic and Tethys oceans (Sheridan, 1983; Arthur et al., 1985). It is tempting to speculate that elevated $\mathrm{CO}_{2}$ levels during the Callovian-Oxfordian may have also been caused by widespread volcanism in the mega-Pacific associated with the disruption of pre-Pacific Plate spreading patterns and in the central Atlantic-Tethys seaway with active spreading of their newly formed ridge systems.

The lack of Jurassic carbonate preservation in the Pacific presents a major question: how was the global geochemical cycle of calcium and carbon balanced? Especially during the middle and late Callovian and early Oxfordian, the areal extent of active carbonate deposition appears to be very restricted; pelagic sedimentation in the Pacific and in the Atlantic-Tethys seaway is nearly devoid of carbonate, and much of the shelf-slope sedimentation consists of organic-rich mudstones (e.g., Spiti Shale in the Himalayas, Oxford Clay in England, Terres Noires in France, etc.). Carbonate platforms active during the middle Callovian through early Oxfordian have a reduced areal extent compared to the Bajocian-Bathonian and the middle Oxfordian-Kimmeridgian. It appears that the carbon cycle during the middle Callovian through early Oxfordian was being balanced by burial of organic carbon, rather than by precipitation of $\mathrm{CaCO}_{3}$.

\section{Cyclic Sedimentation}

The relative abundance of biogenic sedimentation, both of radiolarians and of carbonate, varied relative to clay at most sites. Orbital precession, modulated by eccentricity, is considered to be a major cause of long-term climatic variability in tropical latitudes during the middle and Late Cretaceous (Oglesby and Park, 1989). Probably during the Jurassic and Early Cretaceous, the same orbital variations played a major role in controlling the biological productivity and influx of terrigenous clay to the sites, and may also have caused variations in the strength and oxygen level of bottom currents. In all sites having adequate recovery and biostratigraphy, these clay-rich and -poor alternations display periods consistent with orbital precession cycles (approximately $20,000 \mathrm{yr}$ ), modulated by orbital eccentricity cycles $(95,000 \mathrm{yr}, 123,000 \mathrm{yr}$ and $400,000 \mathrm{yr})$.

Early Cretaceous cycles of deep-sea pelagic sedimentation with similar periodicities are displayed in the Atlantic-Tethys seaway (Cotillon et al., 1980; Cotillon and Rio, 1984; Ogg et al., 1987; Huang, 1991), and such cycles may correlate directly to those within the Pacific (Cotillon, 1984, 1987). However, unlike their Atlantic equivalents, the Pacific cycles do not display major changes in bottom-water oxygen levels and organic-carbon preservation. These open-ocean cycles of both the Pacific and Atlantic are probably the result of fluctuations in surface nutrient upwelling and associated productivity of nannofossils and radiolarians coupled with variations in the intensity of deep-water circulation. Enhanced or decreased pole-to-equator temperature gradients caused by Milankovitch cycles of Earth orbital parameters would lead to variations in the intensity of tropical winds and associated strength of tropical oceanic gyres and would alter the rates of production of colder bottom waters at higher latitudes. Other climatic and oceanographic feedbacks to Milankovitch cycles were probably also involved. Longer-term factors governing the types of response of each ocean basin to Milankovitch cycles are changes in the configuration of the continents and connecting seaways and in access to high-latitude regions.

The Late Jurassic and Early Cretaceous is generally considered to have been a warmer world than today. There is no evidence of polar ice or glacier formation, and fauna and flora considered to be tropical extended to higher latitudes. Central Atlantic bottom-water temperatures during the Early Cretaceous (within laminated portions of cycles) were about $11^{\circ} \mathrm{C}$ (Haggerty, 1987). Therefore, some paleoceanographers have assumed that the Pacific Ocean would have sluggish or even anoxic deep- or mid-depth waters and an expanded oxygen-minimum zone (e.g., Thiede et al., 1982; Vogt, 1989; Theyer et al., 1989; Sliter, 1989). Surprisingly, the sedimentary record suggests that the Mesozoic Pacific had levels of productivity and bottom circulation comparable to the present Pacific. Therefore it is probable that average rates of near-equatorial divergence and associated tropical gyres were also comparable. In addition, the magnitude of the recorded sedimentary response of the Mesozoic Pacific to Milankovitch cycles indicates that these periodic climate and oceanic variations in circulation and upwelling were as critical to productivity as the average "steady-state" condition of the Mesozoic.

\section{Metalliferous and Clay Components}

\section{Iron and Manganese}

The input of FeMn-oxides to oceanic sediments depends on distance from the ridge and spreading rates, but also displays pulses corresponding to episodes of plate reorganization (Leinen and Stakes, 1979; Owen and Rea, 1985; Olivarez and Owen, 1989; Rea et al., 1990). It would be expected that pelagic sediments deposited during such tectonic episodes may have elevated levels of FeMn-oxide and of Fe-smectite clays. An episode of clay-enrichment in the middle Tithonian at Site 801 may be a by-product of the reorganization of Pacific spreading centers between magnetic polarity chrons M20 and M21 (Sager et al., 1988; Handschumacher et al., 1988; Nakanishi et al., 1989) and reversal of plate motion (Fig. 3). Another set of widespread spreading center disruptions occurred in the Pacific during the late Valanginian between magnetic polarity chrons M11 and M10 (Sager et al., 1988; Nakanishi et al., 1989). This episode and possible associated regional volcanic activity may have contributed to the deposition of clay-rich radiolarite at Site 196 and may be exhibited at Site 801 as a hardground overlain by distal volcanic turbidites. Low recovery and lack of logging through the Valanginian at other sites prevents verification of such a Fe-clay enrichment episode.

The anomalously low $\mathrm{Mn}$ values in the Callovian radiolarites at Site 801 may be the result of slightly lower $\mathrm{pH}$ values within the depositing sediments preventing precipitation of Mn-oxide, lower oxygenation of the bottom waters, or subsequent diagenetic mobilization and removal.

\section{Aluminum and Clay}

The accumulation rate of $\mathrm{Al}$, a proxy for the amount of terrigenous and volcanic detrital clay input, is typically $10-20 \mathrm{~g} /$ $\mathrm{cm}^{2} / \mathrm{m}$.y. for Sites 800 and 801 and for the Pacific Rim exposures of radiolarian chert. The $\mathrm{Al}$ values for other Pacific sites were computed from the estimates of average clay content (bulk chemical analyses were not available). The present eastern tropical Pacific has typical Cenozoic accumulation rates of $1-3 \mathrm{~g} / \mathrm{cm}^{2} / \mathrm{m} . y$., rising to $15-$ $20 \mathrm{~g} / \mathrm{cm}^{2} / \mathrm{m}$.y. north of $10^{\circ} \mathrm{N}$ (Leinen and Stakes, 1979). Dust fluxes within the equatorial and northern Pacific increased significantly during glacial times, due to higher average wind velocities and arid continental conditions leading to accelerated eolian erosion and transport (Rea et al., 1991; Hovan et al., 1991). Continental deposits in western North America during much of the Jurassic consist of eolian and fluvial sandstones and redbeds, indicating a relatively dry environment which was probably subject to monsoonal wet/dry cycles (J. Parrish, pers. comm., 1990). These arid continental conditions probably contributed a high influx of Al-rich clay into the central equatorial Pacific during the Jurassic and Early Cretaceous, 
carried to the sites by the tradewinds or by monsoonal-influenced wind patterns.

The flux of Al-rich clay changes on both the short-term and long-term scales. The clay-rich and clay-poor alternations found at most sites are largely caused by variations in biogenic productivity, but may also incorporate changes in the flux of clay in response to the same Milankovitch climate cycles. For example, equatorial Pacific sediments deposited during glacial periods of the late Pleistocene have increased eolian influx coinciding with increased surface productivity and associated mass accumulation rates of carbonate, organic carbon and biogenic silica, although the maxima of each flux do not always coincide (Rea et al., 1991). In contrast, prior to $350 \mathrm{ka}$, Pleistocene sediments deposited in the northwestern Pacific display maxima in mass accumulation rates of carbonate during the interglacial periods (Hovan et al., 1991), whereas coeval sediments deposited in the equatorial Pacific display maxima coinciding with glacial periods (Hays et al., 1969; Farrell and Prell, 1989). For the Late Jurassic and Early Cretaceous, the assignment of variations in clay influx and biogenic mass accumulation rates to "warm" vs. "cool" portions of the Milankovitch cyclicity remains model-dependent.

On a longer time scale, the Valanginian clayey radiolarites at Sites 800 and 801 have higher $\mathrm{Al}$ accumulation rates than the underlying Jurassic radiolarites. The Hauterivian-Barremian estimates of $\mathrm{Al}$ accumulation at Sites 167 and 463 suggest that this trend may continue through the Early Cretaceous. Alternatively, this increased $\mathrm{Al}$ influx may correlate to motion into latitudes farther south of the equator. However, without bulk geochemical data at these other Pacific sites, the validity of this apparently increased $\mathrm{Al}$ influx is uncertain.

The clay content of sediment deposited in a near-ridge setting is further increased by the deposition or authigenic formation of Fe-smectites. These $\mathrm{Fe}$-smectites are a product of $\mathrm{Fe}$-rich emanations from hydrothermal vents, but it is debated whether the Fe-smectites form in situ from a reaction of $\mathrm{Fe}$ ions and biogenic silica or are conveyed to the sediments as pre-formed clay (reviewed in Weaver, 1989). The relatively high clay content of the metalliferous Callovian sediments at Site 801 and of the Barremian sediments at Sites 304 and 303 coincide with proximity to the spreading ridge; therefore, a significant portion of this clay-enrichment is probably from authigenic $\mathrm{Fe}$-smectites.

Another source of low-Al clays is altered volcanic detritus. This type of clay enrichment is important at several sites during the late Barremian-early Aptian.

\section{Deep-Ocean Pacific Radiolarites}

Bedded radiolarite or radiolarian chert is a widespread pelagic sediment within Triassic-Jurassic sections in the Mediterranean and Pacific-Rim regions, and has been the topic of numerous sedimentological, petrological, geochemical, and paleoceanographic studies (e.g., Grunau, 1965; Garrison and Fischer, 1969; Nisbet and Price, 1974; Bosellini and Winterer, 1975; Folk and McBride, 1978; McBride and Folk, 1979; Kälin et al., 1979; Barrett, 1981a, 1981b, 1982; Jenkyns and Winterer, 1982; Baltuck, 1982, 1983; Karl, 1984, 1989; Ruiz-Ortiz et al., 1989; and reviews by Hein and Karl, 1983; Jones and Murchey, 1986; Hein and Parrish, 1987; Baumgartner, 1987; De Wever, 1989; Hein and Obradovic, 1989, to cite only a few). Common models for the origin of rhythmic bedded radiolarian cherts include radiolarian productivity variations, diagenetic segregation of silica, current transport and reworking of radiolarians, turbidite deposition of radiolarians from shallower depths, and intermittent deposition of clay. Depositional environment range from adjacent to continental slopes to marginal-sea basins to open-ocean. It is probable that rhythmic bedding of radiolarian cherts can originate in several different ways, and that these radiolarites can form in any setting that has a high radiolarian productivity. Although the conclusions of these studies often differ regarding the significance and origin of bedded radiolarites, it is generally recognized that the processes of silicification have variably enhanced or obscured the primary sediment features.

Until Leg 129, there were no well-documented occurrences of bedded radiolarian cherts from a definite open-ocean setting, although the abundance of accreted Pacific Rim deposits of Triassic through Early Cretaceous age suggested such sediments were probably present. Previous sites had Lower Cretaceous sediments consisting of radiolarian-rich chert-bearing carbonates and claystones (Table 5), but not "typical" red radiolarian cherts with their well-known ribbon-bedding. Sites 800 and 801 have recovered sediments from below the $3500 \mathrm{~m}$ CCD of the Early Cretaceous Pacific, which indicate that the common deep-sea sediment in tropical latitudes was a clayey radiolarite with alternations of radiolarian-rich and -poor layers. A similar radiolarite characterizes Pacific tropical sedimentation during the Middle and Late Jurassic when no carbonate was preserved even at ridge-depths. The radiolarian-rich/-poor alternations appear to arise from orbitaldriven climatic-oceanographic cycles and are enhanced by dissolution of silica from clay-rich layers and precipitation in the adjacent radiolarian-rich layers.

Most of the radiolarites within the clay-rich and carbonate-rich facies of the central Pacific have locally silicified horizons and concretions of porcellanite or chert (Lancelot, 1973; Keene, 1975; Behl and Smith, this volume). Clay inhibits silica recrystallization of biogenic opal-A to diagenetic opal-CT and can preserve radiolarians during early diagenesis, whereas carbonate drives the reaction faster to quartz (Kastner et al., 1977). Discontinuous or coalescing porcellanite/chert nodules form at semi-regular stratigraphic intervals; this semi-regular spacing in otherwise mostly homogeneous sediments may be the result of centers of silicification lowering the concentration of dissolved silica in the surrounding sediment, thereby inhibiting nucleation in proximity to earlier-formed bands or nodules. Similar semi-regular concretion layers are observed in other types of sediments (Bjørkum and Walderhaug, 1990).

In the upper Tithonian, an 18-m interval with low clay content consists entirely of bedded radiolarian chert. This bedded chert inter$\mathrm{val}$, which corresponds to the transit of Site 801 beneath the equatorial high-productivity zone, is similar in some respects to the Mediterranean and Pacific-Rim chert sections, but the character of bedding is more irregular, with bifurcations and pinch-and-swell distortions to the "ribbon" beds. It is possible that the original sediment lacked well-defined clay-rich and radiolarian-rich layers, and that the formation of the irregular chert bands was the result of coalescence of nodules.

Some of the radiolarite intervals in these sites have regular bedding, especially in the less extensively bioturbated Callovian at Site 801 and Valanginian at Site 800 , but have not yet undergone complete dissolution/reprecipitation of silica and transformation to alternating chert/clay bands. The abundance of clay within these radiolarites has probably inhibited the process of silicification (Kastner et al., 1977). A large portion of this clay consists of Fe-smectites, and it is conceivable that with diagenesis at higher temperatures, the $\mathrm{Fe}$-smectites may be transformed, releasing Fe and Silica. The processes and conditions for smectite decomposition or transformation to illite or chlorite are poorly understood (Chamley, 1989, and Weaver, 1989, and references therein). Perhaps with either longer or deeper burial, these clay-rich radiolarites will undergo further silicification and segregation of clay. Diagenetic enhancement is important, but not sufficient, to produce a "ribbon-bedded" radiolarite; a primary sediment alternation is required.

Radiolarites dominate the Pacific sedimentation throughout the Jurassic and are the main sediment deposited during the Early Cretaceous below ridge-depths. The accumulation rate of the biogenic silica, and the relative amounts of silica and clay are primarily influenced by the latitude of deposition. The most rapid accumulation of radiolarians, and hence the most favored depositional environment for transformation to bedded cherts, is under the paleoequator. 


\section{SUMMARY}

We have analyzed the lithology, petrology, and mass accumulation rates of Jurassic and Lower Cretaceous sediments from Leg 129 Sites 801 and 800 and from a suite of other DSDP sites. Sedimentation at these sites took place in equatorial latitudes, from $10^{\circ} \mathrm{N}$ to $18^{\circ} \mathrm{S}$. The Middle through Late Jurassic history of the central Pacific is known mainly through the core recovery and logging data at Site 801, and from obducted chert-rich sections around the Pacific Rim. The Early Cretaceous history is well-documented at several sites. When placed on a framework of paleolatitude and paleodepth, general patterns of biogenic silica and carbonate sedimentation are evident. Some of our main conclusions are:

1. Paleomagnetic data indicate that the Pacific Plate experienced a northward drift of about $8^{\circ}-10^{\circ}$ from Callovian to middle Tithonian (Fig. 3, Table 5). Following a middle Tithonian change in drift direction, the Pacific Plate underwent a total of $15^{\circ}$ of southward paleolatitude drift during the Early Cretaceous (Barremian). During this interval, the Hawaiian and Japanese ridges remained stationary at about $10^{\circ} \mathrm{N}$. The Shatsky Rise hotspot indicates that east-west longitudinal drift from at least middle Tithonian to middle Valanginian was not significant. After reaching its most southerly position in the early Aptian, the Pacific Plate has drifted northward or northwestward with about $35^{\circ}$ of total northward latitude change to its present position.

2. At Site 801 , the Callovian hematite-rich red radiolarite is unconformable on the basaltic basement of latest Bathonian-earliest Callovian age. The basal meters of the sediment section consist of a series of slump and breccia deposits. Within the basalt flows are several thin lenses of carbonate- and metal-enriched radiolarian claystones, porcellanites and cherts, and a thick layer of hydrothermally deposited iron-rich quartz. Oxfordian through Valanginian brown radiolarites are unconformable on the tilted Callovian strata, and contain abundant manganese oxide. The middle Tithonian consists of bedded radiolarian chert. An upper Valanginian hardground terminates the main episode of radiolarite deposition, and is overlain by distal volcaniclastic turbidites. Another interval of radiolarian claystone overlies this first pulse of middle Cretaceous volcanism and, in turn, is overlain by a thick accumulation of volcaniclastic turbidites and grain flows of Aptian to Albian age associated with the formation of adjacent seamounts.

3. Jurassic through Lower Cretaceous sediments are mainly a mixture of biogenic silica, clay, and carbonate. Enrichment in $\mathrm{Fe}$ and Mn oxides occurs especially when sites were closer to active ridges. Volcanic ash or volcaniclastic turbidites were important constituents beginning in the late Barremian.

4. Biogenic silica influx, in the form of radiolarian tests, depended primarily upon the proximity of the site to the paleoequator (Fig. 11). Bedded radiolarian cherts occur at Site 801 as a result of high silica influx during its middle Tithonian proximity to the paleoequator.

5. Carbonate preservation, mainly in the form of nannofossils, was mainly a function of geological age. The Pacific CCD remained above $2700 \mathrm{~m}$ through the Jurassic, dropped to about $3500 \mathrm{~m}$ during the Berriasian through Hauterivian, then rose during the Barremian and Aptian. The depth history of the Pacific CCD is probably a mirror of global atmospheric-oceanic $\mathrm{CO}_{2}$ levels.

6. Clay abundance in the sediment depends on the influx of terrigenous Al-clay and upon the formation of authigenic Fe-smectites. Authigenic Fe-smectite formation was especially important to sites close to active spreading ridges.

7. All Jurassic and Lower Cretaceous sediments were deposited under oxygenated bottom-water conditions, accompanied by bioturbation and pervasive oxygenation of organic carbon and metals.

8. Callovian radiolarites at Site 801 are enriched in Fe, but depleted in $\mathrm{Mn}$, relative to the overlying Oxfordian radiolarites. The anomalous
Mn-depletion probably resulted either from relatively reducing conditions in the buried sediments, or from a relatively lower $\mathrm{pH}$ induced by higher levels of dissolved $\mathrm{CO}_{2}$ in the bottom or interstitial waters.

9. Cycles of biogenic accumulation, both as radiolarians and as carbonate, are common at all depths, paleolatitudes, and geological ages. These cycles appear to correspond to the 20,000 yr Milankovitch period of climate change induced by precession of the Earth's orbit, and are modulated by the $95,000-\mathrm{yr}, 123,000-\mathrm{yr}$, and 400,000-yr periods of eccentricity. The Milankovitch cycles probably vary the strength of upwelling and surface productivity, and may also alter the influx of eolian clay and the dissolution rate of carbonate and biogenic silica in bottom sediments.

10. Diagenesis has enhanced primary alternations of radiolarianrich and clay-rich layers. Ribbon-bedding of radiolarian cherts may be formed from silicification of radiolarites deposited near the equatorial high-productivity zone. Discontinuous bands and/or nodules of porcellanite and chert results from silicification processes in sediments that are extensively mixed by bioturbation or are enriched in clay or carbonate.

\section{ACKNOWLEDGMENTS}

We thank the Ocean Drilling Program for inviting our participation on Leg 129. Many of the observations and ideas expressed in this paper grew out of discussions with our shipboard colleagues, especially Anne-Marie Karpoff, Brian Wallick, Yves Lancelot, and Roger Larson. Financial support for our participation and post-cruise research was from the U.S. Science Advisory Committee and the Joint Oceanographic Institutions (J.G.O. and R.B.) and the U.S. Geological Survey (S.M.K.). This paper was greatly improved by discussions and reviews from Jerry Winterer, Roger Larson, Gabi Ogg, Brian Wallick, Atsushi Matsuoka, Felix Gradstein, and Hugh Jenkyns.

\section{REFERENCES}

Aoki, S., Kohyama, N., and Sudo, T., 1974. An iron-rich montmorillonite in a sediment core from the northeastern Pacific. Deep-Sea Res. Part A, 21:865-875.

Arthur, M. A., 1979. Origin of Upper Cretaceous multicolored claystones of the Western Atlantic. In Tucholke, B. E., Vogt, P. R., et al., Init. Repts. DSDP, 43: Washington (U.S. Govt. Printing Office), 417-420.

Arthur, M. A., Brumsack, H.-J., Jenkyns, H. C., and Schlanger, S. O., 1990. Stratigraphy, geochemistry, and paleoceanography of organic carbon-rich Cretaceous sequences. In Ginsburg, R. N., and Beaudoin, B. (Eds.), Cretaceous Resources, Events and Rhythms: Amsterdam (Kluwer Academic), 75-119.

Arthur, M. A., Dean, W. E., and Schlanger, S. O., 1985. Variations in the global carbon cycle during the Cretaceous related to climate, volcanism, and changes in atmospheric $\mathrm{CO}_{2}$. In Sundquist, E. T., and Broecker, W. S. (Eds.), The Carbon Cycle and Atmospheric $\mathrm{CO}_{2}$ : Natural Variations Archean to Present. Am. Geophys. Union Monogr., 32:504-529.

Azéma, J., and Blanchet, R., 1982. The Late Jurassic-Early Cretaceous genus Calpionella in reworked pebbles from Deep Sea Drilling Project Site 460, Mariana transect. In Hussong, D. M., Uyeda, S., et al., Init. Repts. DSDP, 60: Washington (U.S. Govt. Printing Office), 575-576.

Baltuck, M., 1982. Provenance and distribution of Tethyan pelagic and hemipelagic siliceous sediments, Pindos Mountains, Greece. Sediment. Geol., 31:63-88.

, 1983. Some sedimentary and diagenetic signatures in the formation of bedded radiolarite. In lijima, A., Hein, J. R., and Siever, R. (Eds.), Siliceous Deposits in the Pacific Region, Amsterdam (Elsevier), Dev, in Sedimentol. Ser., 36:299-315.

Barrett, T. J., 1981a. Stratigraphy and sedimentology of Jurassic bedded chert overlying ophiolites in the north Apennines, Italy. Sedimentology, 29:353-373.

, 1981b. Chemistry and mineralogy of Jurassic bedded chert overlying ophiolites in the north Apennines, Italy. Chem. Geol., 34:289-317. 1982. Jurassic bedded cherts from the north Apennines, Italy: dyscyclic sedimentation in the deep pelagic realm. In Einsele, G., and 
Seilacher, A. (Eds.), Cyclic and Event Stratification: New York (SpringerVerlag), 389-403.

Baumgartner, P. O., 1984. A Middle Jurassic-Early Cretaceous low-latitude radiolarian zonation based on Unitary Associations and age of Tethyan radiolarites. Eclogae Geol. Helv., 77:729-837.

1987. Age and genesis of Tethyan Jurassic radiolarites. Eclogae Geol. Helv., 80:831-879.

Berger, W. H., 1973. Cenozoic sedimentation in the eastern tropical Pacific. Geol. Soc. Am. Bull., 84:1941-1954.

Berger, W. H., and Winterer, E. L., 1974. Plate stratigraphy and the fluctuating carbonate line. In Hsü, K. J., and Jenkyns, H. C. (Eds.), Pelagic Sediments on Land and Under the Sea. Spec. Publ. Int. Assoc. Sedimentol., 1:11-48.

Berner, R. A., 1990. Atmospheric carbon dioxide levels over Phanerozoic time. Science, 249:1382-1386.

Bjørkum, P. A., and Walderhaug, O., 1990. Geometrical arrangement of calcite cementation within shallow marine sandstones. Earth-Sci. Rev. $29: 145-161$.

Bode, G. W., 1973. Appendix II. Carbon and carbonate analyses, Leg 17. In Winterer, E. L., Ewing, J. I., et al., Init. Repts. DSDP, 17: Washington (U.S. Govt. Printing Office), 927-930.

1975. Carbon and carbonate analyses, Leg 32. In Larson, R. L. Moberly, R., et al., Init. Repts. DSDP, 32: Washington (U.S. Govt. Printing Office), 561-562.

Bonatti, E., 1975. Metallogenesis at oceanic spreading centers. Annu. Rev. Earth Planet. Sci., 3:401-431.

Bosellini, A., and Winterer, E. L., 1975. Pelagic limestone and radiolarite of the Tethyan Mesozoic: a genetic model. Geology, 3:279-282.

Boström, K., and Peterson, M.N.A., 1969. The origin of aluminum-poor ferromanganoan sediments in areas of high heat flow on the East Pacific Rise. Mar. Geol., 1:427-447.

Boström, K., Peterson, M.N.A., Joensuu, O., and Fisher, D. E., 1969. Aluminum-poor ferromanganoan sediments on active oceanic ridges. J. Geophys. Res., 74:3261-3270.

Bralower, T. J., Monechi, S., and Thierstein, H. R., 1989. Calcareous nannofossil zonation of the Jurassic-Cretaceous boundary interval and correlation with the geomagnetic polarity timescale. Mar. Micropaleontol., 14:153-235.

Brookins, D. G., 1988. Eh-pH Diagrams for Geochemistry: New York (Springer-Verlag).

Brueckner, H. K., Snyder, W. S., and Boudreau, M., 1987. Diagenetic controls on the structural evolution of siliceous sediments in the Golconda allochthon, Nevada, U.S.A. J. Struct. Geol., 9:403-417.

Carbotte, S. M., and Macdonald, K. C., 1990. Causes of variation in fault-facing direction on the ocean floor. Geology, 18:749-752.

Chamley, H., 1989. Sedimentology: New York (Springer-Verlag).

Cotillon, P.. 1984. Tentative world-wide correlation of Early Cretaceous strata by limestone-marl cyclicities in pelagic deposits. Bull. Geol. Soc. Den., 33:91-102

, 1987. Bed-scale cyclicity of pelagic Cretaceous successions as a result of world-wide control. Mar. Geol,. 78:109-123.

Cotillon, P., and Rio, M., 1984. Cyclic sedimentation in the Cretaceous of Deep Sea Drilling Project Sites 535 and 540 (Gulf of Mexico), 534 (Central Atlantic), and in the Vocontian Basin (France). In Buffler, R. T., Schlager, W., et al., Init. Repts. DSDP, 77: Washington (U.S. Govt. Printing Office), 339-376.

Cotillon, P., Ferry, S., Gaillard, C., Jautée, E., Latreille, G., and Rio, M., 1980 Fluctuation des paramètres du milieu marin dans le domaine vocontien (France Sud-Est) au Crétacé inférieur: mise en évidence par l'étude des formations marno-calcaires alternantes. Bull. Soc. Geol. Fr., 22:735-744.

Cronan, D. S., 1969. Average abundances of Mn, Fe, Ni, Co, Cu, Pb, Mo, V, $\mathrm{Ce}, \mathrm{Ti}$, and $\mathrm{P}$ in Pacific pelagic clays. Geochim. Cosmochim. Acta 33:1562-1565

Dean, W. E., 1981. Calcium carbonate and organic carbon in samples from Deep Sea Drilling Project Sites 463, 464, 465, and 466. In Thiede, J., Vallier, T. L., et al., Init. Repts. DSDP, 62: Washington (U.S. Govt. Printing Office), 869-876.

Dean, W. E., Claypool, G. E., and Thiede, J., 1981. Origin of organic-carbonrich Mid-Cretaceous limestones, Mid-Pacific Mountains and southern Hess Rise. In Thiede, J., Vallier, T. L., et al., Init. Repts. DSDP, 62 Washington (U.S. Govt. Printing Office), 877-890.

Dean, W. E., Gardner, J.V., and Hemphill-Haley, E., 1989. Changes in redox conditions in deep-sea sediments of the Subarctic North Pacific Ocean: possible evidence for the presence of North Pacific Deep Water. Paleoceanography, 4:639-653.

De Wever, P., 1982. Radiolaires du Trias et du Lias de la Téthys (Systématique, Stratigraphie). Soc. Geol. Nord, 7.

1987. Radiolarites rubanées et variations de l'orbite terrestre. Bull. Soc. Geol. Fr., 8:957-960.

1989. Radiolarians, radiolarites, and Mesozoic paleogeography of the Circum-Mediterranean alpine belts. In Hein, J. R., and Obradovic, J. (Eds), Siliceous Deposits of the Tethys and Pacific Region: New York (Springer-Verlag), 31-49.

Donnelly, T. W., and Wallace, J. L., 1976. Major element chemistry of the Tertiary rocks at Site 317 and the problem of the origin of the nonbiogenic fraction of pelagic sediments. In Schlanger, S. O., Jackson, E. D., et al., Init. Repts. DSDP, 33: Washington (U.S. Govt. Printing Office), 557-562.

Dymond, J., 1981. The geochemistry of Nazca plate surface sediments: an evaluation of hydrothermal, biogenic, detrital, and hydrogenous sources. In Kulm, L. D., et al. (Eds.), Nazca Plate: Crustal Formation and Andean Convergence. Mem.-Geol. Soc. Am., 154:133-174.

Emerson, S., and Hedges, J. I., 1988. Processes controlling the organic carbon content of open ocean sediments. Paleoceanography, 3:621-634.

Farrell, J. W., and Prell, W. L., 1989. Climatic change and $\mathrm{CaCO}_{3}$ preservation: an 800,000 year bathymetric reconstruction from the central equatorial Pacific Ocean. Paleoceanography, 4:447-466.

Floyd, P. A., Castillo, P. R., and Pringle, M., 1991. Tholeiitic and alkalic basalts of the oldest Pacific Ocean crust. Terra Nova, 3:257-265.

Folk, R. L., and McBride, E. F., 1978. Radiolarites and their relation to subjacent "oceanic crust" in Liguria, Italy. J. Sediment. Petrol., 48:1069-1102.

Froelich, P. N., Klinkhammer, G. P., Bender, M. L., Luedke, L. A., Heath, G. R., Cullen, C., Dauphin, P., Hammond, D., Hartmann, B., and Maynard, V., 1979. Early oxidation of organic matter in pelagic sediments of the Eastern Equatorial Pacific, suboxic diagenesis. Geochim. Cosmochim. Acta, 43:1075-1090.

Froelich, P. N., Malone, P. N., Hodell, D. A., Ciesielski, P. F., Warnke, D. A., Westall, F., Hailwood, E. A., Nobes, D. C., Fenner, J., Mienert, J., Mwenifumbo, C. J., and Müller, D. W., 1991. Biogenic opal and carbonate accumulation rates in the SubAntarctic South Atlantic: the late Neogene of Meteor Rise Site 704. In Ciesielski, P. F., Kristoffersen, Y., et al., Proc. ODP, Sci. Results, 114: College Station, TX (Ocean Drilling Program), 515-550.

Fullerton, L. G., Sager, W. W., and Handschumacher, D. W., 1989. Late Jurassic-Early Cretaceous evolution of the eastern Indian Ocean adjacent to Northwest Australia. J. Geophys. Res., 94:2937-2953.

Garrison, R. E., and Fischer, A. G., 1969. Deep water limestones and radiolarites of the Alpine Jurassic. In Friedman, G. M. (Ed.), Depositional Environments in Carbonate Rock: A Symposium. Spec. Publ.-Soc. Econ. Paleontol. Mineral., 14:20-56.

Gee, J., Staudigel, H., and Tauxe, L., 1989. Contribution of induced magnetization to magnetization of seamounts. Nature, 342:170-173.

Goldberg, E. D., and Arrhenius, G.O.S., 1958. Chemistry of Pacific pelagic sediments. Geochim. Cosmochim. Acta, 13:153-212.

Gordon, R. G., 1982. Paleomagnetic test of the Emperor Fracture zone hypothesis. Geophys. Res. Lett., 9:1283-1286.

-1990 . Test for bias in paleomagnetically determined paleolatitudes from Pacific Plate Deep Sea Drilling Project sediments. J. Geophys. Res. 95:8397-8404.

Grunau, H. R., 1965. Radiolarian cherts and associated rocks in space and time. Eclogae Geol. Helv., 58:157-208.

Gursky, H.-J., and Schmidt-Effing, R., 1983. Sedimentology of radiolarites within the Nicoya Ophiolite Complex, Costa Rica, Central America. In Iijima, A., Hein, J. R., and Siever, R., Siliceous Deposits in the Pacific Region: Amsterdam (Elsevier), Dev. in Sedimentol., 36:127-142.

Habib, D., 1983. Sedimentation-rate-dependent distribution of organic matter in the North Atlantic Jurassic-Cretaceous. In Sheridan, R. E., Gradstein, F. M., et al., Init. Repts. DSDP, 76: Washington (U.S. Govt. Printing Office), 781-794.

Habib, D., and Drugg, W. S., 1983. Dinoflagellate age of Middle Jurassic-Early Cretaceous sediments in the Blake-Bahama Basin. In Sheridan, R. E., Gradstein, F. M., et al., Init. Repts. DSDP, 76: Washington (U.S. Govt. Printing Office), 623-638.

Haggerty, J. A., 1987. Petrology and carbon and oxygen stable isotopic composition of macrofossils and sediments from the Blake-Bahama Formation, Deep Sea Drilling Project Site 603, western North Atlantic, lower continental rise. In van Hinte, J. E., Wise, S. W., Jr., et al., Init. Repts. DSDP, 93: Washington (U.S. Govt. Printing Office), 1003-1021. 
Hagstrum, J. T., and Sedlock, R. L., 1990. Remagnetization and northward translation of Mesozoic red chert from Cedros Island and the San Benito Islands, Baja California, Mexico. Geol. Soc. Am. Bull., 102:983-991.

Hagstrum, J. T., and Sedlock, R. L., 1991. Remagnetization and northward translation of Mesozoic red chert from Cedros Island and the San Benito Islands, Baja California, Mexico: reply. Geol. Soc. Am. Bull., 103:968-969.

Hammond, S. R., Kroenke, L. W., and Theyer, F., 1975. Northward motion of the Ontong-Java Plateau between -110 and -30 M.Y. In Andrews, J. E., Packham, G., et al., Init. Repts. DSDP, 30: Washington(U.S. Govt. Printing Office), 415-418.

Handschumacher, D. W., Sager, W. W., Hilde, T.W.C., and Bracey, D. R., 1988. Pre-Cretaceous tectonic evolution of the Pacific plate and extension of the geomagnetic polarity reversal time scale with implications for the origin of the Jurassic "Quiet Zone." Tectonophysics, 155:365-380.

Harland, W. B., Cox, A. V., Llewellyn, P. G., Pideton, C.A.G., Smith, A. G., and Walters, R., 1982. A Geologic Time Scale: Cambridge (Cambridge Univ. Press).

Hays, J. D., Satio, T., Opdyke, N. D., and Burckle, L. H., 1969. Pliocene-Pleistocene sediments of the equatorial Pacific: their paleomagnetic, biostratigraphic, and climatic record. Geol. Soc. Am. Bull., 80:1481-1514.

Heath, G. R., and Dymond, J., 1977. Genesis and transformation of metalliferous sediments from the East Pacific Rise, Bauer Deep, and Central Basin, northwest Nazca plate. Geol. Soc. Am. Bull., 88:723-733.

Hein, J. R., and Karl, S. M., 1983. Comparisons between open-ocean and continental margin chert sequences. In Iijima, A., Hein, J. R., and Siever, R. (Eds.), Siliceous Deposits in the Pacific Region. Amsterdam (Elsevier), Dev. in Sedimentol. Ser., 36:25-44.

Hein, J. R., Kuijpers, E. P., Denyer, P., and Sliney, R. E., 1983. Petrology and geochemistry of Cretaceous and Paleogene cherts from western Costa Rica. In Iijima, A., Hein, J.R., and Siever, R., Siliceous Deposits in the Pacific Region. Amsterdam (Elsevier), Dev. in Sedimentol. Ser., 36:143-174.

Hein, J. R., and Obradovic, J., 1989. Siliceous deposits of the Tethys and Pacific regions. In Hein, J. R., and Obradovic, J. (Eds.), Siliceous Deposits of the Tethys and Pacific Region: New York (Springer-Verlag), 1-17.

Hein, J. R., and Parrish, J. T., 1987. Distribution of siliceous deposits in space and time. In Hein, J. R. (Ed.), Siliceous Sedimentary Rock-Hosted Ores and Petroleum: New York (Van Nostrand Reinhold), 10-57.

Hilde, T.W.C., Isezaki, N., and Wageman, J. M., 1976. Mesozoic sea-floor spreading in the North Pacific. In Woolard, G. P., Sutton, G. H., Manghnani, M. H., and Moberly, R. (Eds.), The Geophysics of the Pacific Ocean Basin and its Margins. Am. Geophys. Union, Geophys. Monogr., 19:205-226.

Hovan, S. A., Rea, D. K., and Pisias, N. G., 1991. Late Pleistocene continental climate and oceanic variability recorded in Northwest Pacific sediments. Paleoceanography, 6:349-370.

Huang, Z., 1991. Periodicity in Cretaceous pelagic sequences [Ph.D. thesis]. Dalhousie Univ., Halifax.

Hurd, D. C., and Theyer, F., 1975. Changes in the physical and chemical properties of biogenic silica from the Central Equatorial Pacific: I. Solubility, specific surface area and solution rate constants of acid-cleaned samples. Adv. Chem. Ser, 147:211-230.

Iijima, A., Matsumoto, R., and Tada, R., 1985. Mechanism of sedimentation of rhythmically bedded chert. Sediment. Geol., 41:221-233.

Janecek, T., and Rea, D. K., 1983. Eolian deposition of the North Pacific Ocean: Cenozoic history of atmospheric circulation. Geol. Soc. Am. Bull., 94:703-738.

Jenkyns, H. C., and Winterer, E. L., 1982. Paleoceanography of Mesozoic ribbon radiolarites. Earth Planet. Sci. Lett., 60:351-375.

Jones, D. L., and Murchey, B., 1986. Geological significance of Paleozoic and Mesozoic radiolarian chert. Annu. Rev. Earth Planet. Sci., 14:455-492.

Johnson, L. E., Fryer, P., Taylor, B., Silk, M., Jones, D. L., Itaya, T., Ishii, T., 1991. New evidence for crustal accretion in the outer Mariana fore arc: Cretaceous radiolarian cherts and mid-ocean ridge basalt-like lavas. $\mathrm{Ge}$ ology, 19:811-814.

Johnson, T. C., 1975. The dissolution of siliceous microfossils in deep-sea sediments [Ph.D. dissert.]. Univ. of California at San Diego.

Jurassic-Cretaceous Working Group: Baumgartner, P. O., Gorican, S., Jud, R., O'Dogherty, L., Conti, M., Danelian, T., De Wever, P., Dumitrica, P., Kito, N., Marcucci, M., Matsuoka, A., Steiger, T., Urquart, E., in press. A new Middle Jurassic-Early Cretaceous radiolarian biochronology of
Tethys. In Cariou, E., and Hantzpergue, P. (Eds.), 3rd Int. Symp. Jurassic Stratigr., (Poitiers, Sept. 22-29, 1991), Geobios.

Kälin, O., Pattaca, E., and Renz, O., 1979. Jurassic pelagic deposits from southeastern Tuscany: aspects of sedimentation and new biostratigraphic data. Eclogae Geol. Helv., 72:715-762.

Karl, S. M., 1984. Sedimentologic, diagenetic, and geochemical analysis of Upper Mesozoic ribbon cherts from the Franciscan Assemblage at the Marin Headlands, California. In Blake, M. C., Jr. (Ed.), Franciscan Geology of Northern California. Soc. Econ. Paleontol. Mineral., Pacific Sect., 43:71-88.

1989. Paleoenvironmental implications of Alaskan siliceous deposits. In Hein, J. R., and Obradovic, J. (Eds.), Siliceous Deposits of the Tethys and Pacific Region: New York (Springer-Verlag), 169-200.

Karpoff, A. M., Walter, A.-V., and Pflumio, C., 1988. Metalliferous sediments within lava sequences of the Sumail ophiolite (Oman): mineralogical and geochemical characterization, origin and evolution. Tectonophysics, 151:223-245.

Karson, J. A., and Rona, P. A., 1990. Block-tilting, transfer faults, and structural control of magmatic and hydrothermal processes in the TAG area, Mid-Atlantic Ridge $26^{\circ}$ N. Geol. Soc. Am. Bull., 102:1635-1645.

Kastner, M., and Gieskes, J. M., 1983. Opal-A to Opal-CT transformation: a kinetic study. In Lijima, A., Hein, J. R., and Siever, R. (Eds.), Siliceous Deposits in the Pacific Region. Amsterdam (Elsevier), Dev. in Sedimentol., 36:211-230.

Kastner, M., Keene, J. G., and Gieskes, J. M., 1977. Diagenesis of siliceous oozes: I. Chemical controls on the rate of opal-A to opal-CT transformations-an experimental study. Geochim. Cosmochim. Acta, 41:1041-1051.

Keene, J. B., 1975. Cherts and porcellanites from the North Pacific, DSDP Leg 32. In Larson, R. L., Moberly, R., et al., Init. Repts. DSDP, 32: Washington (U.S. Govt. Printing Office), 429-507.

Kent, D. V., and Gradstein, F. M., 1985. A Cretaceous and Jurassic geochronology. Geol. Soc. Am. Bull., 96:1419-1427.

Klitgord, K. D., and Schouten, H., 1986. Plate kinematics of the central Atlantic. In Vogt, P. R., and Tucholke, B. E. (Eds.), The Westem North Atlantic Region (Vol. M): The Geology of North America. Geol. Soc. Am., 351-378.

Kono, M., 1980. Statistics of paleomagnetic inclination data. J. Geophys. Res., $85: 3878-3882$.

Krauskopf, K. B., 1957. Separation of iron from manganese in sedimentary processes. Geochim. Cosmochim. Acta, 12:61-82.

Lancelot, Y., 1973. Chert and silica diagenesis in sediments from the Central Pacific. In Winterer, E. L., Ewing, J. I., et al., Init. Repts. DSDP, 17: Washington (U.S. Govt. Printing Office), 377-405.

- 1978. Relations entre évolution sédimentaire et tectonique de la plaque Pacifique depuis le Crétacé inférieur. Mem. Soc. Geol. Fr., 134.

Lancelot, Y., Hathaway, J. C., and Hollister, C. D., 1972. Lithology of sediments from the western North Atlantic. In Hollister, C. D., Ewing, J. I., et al., Init. Repts. DSDP, 11: Washington (U.S. Govt. Printing Office), 901-949.

Lancelot, Y., and Larson, R. L., 1975. Sedimentary and tectonic evolution of the Northwestern Pacific. In Larson, R. L., Moberly, R., et al., Init. Repts. DSDP, 32: Washington (U.S. Govt. Printing Office), 925-949.

Larson, R. L., 1976. Late Jurassic and Early Cretaceous evolution of the western Central Pacific Ocean. J. Geomagn. Geoelectr., 28:219-236.

, 1977. Early Cretaceous breakup of Gondwanaland off western Australia. Geology, 5:57-60.

, 1991a. Latest pulse of Earth: evidence for a mid-Cretaceous superplume. Geology, 19:547-550.

19:96, 1991b. Geological consequences of superplumes. Geology, 19:963-966.

Larson, R. L., and Chase, C. G., 1972. Late Mesozoic evolution of the western Pacific Ocean. Geol. Soc. Am. Bull., 83:3627-3643.

Larson, R. L., and Hilde, T.W.C., 1975. A revised time scale of geomagnetic reversals for the Early Cretaceous and Late Jurassic. J. Geophys. Res., 80:2586-2594.

Larson, R. L., and Lowrie, W., 1975. Paleomagnetic evidence for motion of the Pacific plate from Leg 32 basalts and magnetic anomalies. In Larson, R. L., Moberly, R., et al., Init. Repts. DSDP, 32: Washington (U.S. Govt. Printing Office), 571-577.

Larson, R. L., Moberly, R., et al., 1975. Init. Repts. DSDP, 32: Washington (U.S. Govt. Printing Office).

Larson, R. L., and Olson, P., 1991. Mantle plumes control magnetic reversal frequency. Earth Planet. Sci. Lett., 107:437-447. 
Larson, R. L., and Pitman, W. C., III, 1972. World-wide correlation of Mesozoic magnetic anomalies and its implications. Geol. Soc. Am. Bull., 83:3645-3662.

Leinen, M., 1989. The pelagic clay province of the North Pacific Ocean. In Winterer, E. L., Hussong, D. M., and Decker, R. W. (Eds.), The Geology of North America (Vol. N): The Eastern Pacific Ocean and Hawaii. Geol. Soc. Am., 323-335.

Leinen, M., and Heath, G. R., 1981. Sedimentary indicators of atmospheric activity in the Northern Hemisphere during the Cenozoic. Palaeogeogr. Palaeoclimatol., Palaeoecol, 36:1-21.

Leinen, M. and Stakes, D., 1979. Metal accumulation rates in the central equatorial Pacific during Cenozoic time. Geol. Soc. Am. Bull., 90:357-375.

Lowrie, W., Channell, J.E.T., and Alvarez, W., 1980. A review of magnetic stratigraphy investigations in Cretaceous pelagic carbonate rocks, J. Geophys. Res., 85:3597-3605.

Lowrie, W., and Ogg, J. G., 1986. A magnetic polarity time scale for the Early Cretaceous and Late Jurassic. Earth. Planet. Sci. Lett., 76:341-349.

Lyle, M., Murray, D. W., Finney, B. P., Dymond, J., Robbins, J. M., and Brooksforce, K., 1988. The record of late Pleistocene biogenic sedimentation in the eastern tropical pacific Ocean. Paleoceanography, 3:39-59.

Macdonald, K. C., 1986. The crest of the Mid-Atlantic Ridge: models for crustal generation: processes and tectonics. In Vogt, P. R., and Tucholke, B. E. (Eds.), The Geology of North America (Vol. M): The Western North Atlantic Region. Geol. Soc. Am., 51-68.

Mangini, A., Eisenhauer, A., and Walter, P., 1990. Response of Manganese in the ocean to the climatic cycles in the Quaternary. Paleoceanography, 5:811-821.

Marty, J. C., and Cazenave, A., 1989. Regional variations in subsidence rate of oceanic plates: a global analysis. Earth Planet. Sci. Lett., 94:301-315.

Matter, A., Douglas, R. G., and Perch-Nielsen, K., 1975. Fossil preservation, geochemistry, and diagenesis of pelagic carbonates from Shatsky Rise, Northwest Pacific. In Larson, R. L., Moberly, R., et al., Init. Repts. DSDP, 32: Washington (U.S. Govt. Printing Office), 891-907.

Matsuda, T., and Isozaki, Y., 1991. Well-documented travel history of Mesozoic pelagic chert in Japan: from remote ocean to subduction zone. Tectonics, 10:475-499.

Matsumoto, R., and Iijima, A., 1983. Chemical sedimentology of some PermoJurassic and Tertiary bedded cherts. In lijima, A., Hein, J. R., and Siever, R. (Eds.), Siliceous Deposits in the Pacific Region: Amsterdam (Elsevier), Dev. in Sedimentol. Ser., 36:175-191.

Matsuoka, A., 1991. Middle Jurassic radiolarians from the western Pacific Saito Ho-on Kai Spec. Publ. (Proceedings of Shallow Tethys 3, Sendai, 1990), 3:163-173.

Matsuoka, A., and Yao, S., 1986. A newly proposed radiolarian zonation for the Jurassic of Japan. Mar. Micropaleontol., 11:91-105.

McBride, E. F., and Folk, R. L., 1979. Features and origin of Italian Jurassic radiolarites deposited on continental crust. J. Sediment. Petrol., $49: 837-868$

McCave, I. N., 1979. Depositional features of organic-carbon-rich black and green mudstones at DSDP Sites 386 and 387, western North Atlantic. In Tucholke, B. E., Vogt, P. R., et al., Init. Repts. DSDP, 43: Washington (U.S. Govt. Printing Office), 411-416.

McMurtry, G. M., Wang, C., and Yeh, H., 1983. Chemical and isotopic investigations into the origin of clay minerals from the Galapagos hydrothermal mounds field. Geochim. Cosmochim. Acta, 47:475-489.

McNutt, M. K., Winterer, E. L., Sager, W. W., Natland, J. H., and Ito, G., 1990. The Darwin Rise: a Cretaceous superswell? Geophys. Res. Lett., 17:1101-1104.

Mélières, F., Deroo, G., and Herbin, J.-P., 1981. Organic-matter-rich and hypersiliceous Aptian sediments from western Mid-Pacific Mountains, Deep Sea Drilling Project Leg 62. In Thiede, J., Vallier, T. L., et al., Init. Repts. DSDP, 62: Washington (U.S. Govt. Printing Office), 903-915

Menard, H. W., 1984. Darwin reprise. J. Geophys. Res., 89:9960-9968.

Menard, H. W., Natland, J. H., Jordan, T. H., Orcutt, J. A., et al., 1987. Init Repts. DSDP, 91: Washington (U.S. Govt. Printing Office).

Meyerhoff Hull, D., and Pessagno, E. A., Jr., 1991. Upper Jurassic radiolarian assemblages from the Stanley Mountain remnant of the Coast Range ophiolite, Southern California Coast Ranges. In Abstract volume of Interrad VI (6th Meeting Int. Assoc. Radiolarian Paleontologists), Univ. Studi di Firenze, 120-121.

Montgomery, A. F., and Johnson, H. P., 1987. In Menard, H. W., Natland, J. H., Jordan, T. H., Orcutt, J. A., et al., 1987. Init. Repts. DSDP, 91: Washington (U.S. Govt. Printing Office), 475-482.
Moore, T. C., Jr., 1969. Radiolaria: change in skeletal weight and resistance to solution. Geol. Soc. Am. Bull., 80:2103-2108.

Nakanishi, M., Tamaki, K., and Kobayashi, K., 1989. Mesozoic magnetic anomaly lineations and seafloor spreading history of the Northwestern Pacific. J. Geophys. Res., 94:15437-15462.

Nisbet, E. G., and Price, I., 1974. Siliceous turbidites: bedded cherts as redeposited ocean ridge-derived sediments. In Hsü, K. J., and Jenkyns, H. C. (Eds.), Pelagic Sediments: On Land and Under the Sea. Int. Assoc. Sediment., Spec. Publ., 1:351-366.

Ogg, J. G., 1986. Paleolatitudes and magnetostratigraphy of Cretaceous and lower Tertiary sedimentary rocks, DSDP Site 585, Mariana Basin, western Central Pacific. In Moberly, R., Schlanger, S. O., Init. Repts. DSDP, 89: Washington (U.S. Govt. Printing Office), 629-645.

, 1988. Early Cretaceous and Tithonian magnetostratigraphy of the Galicia Margin (Ocean Drilling Program Leg 103). In Boillot, G., Winterer, E.L., et al., Proc. ODP, Sci. Results, 103: College Station, TX (Ocean Drilling Program), 659-682.

Ogg, J. G., Haggerty, J., Sarti, M., and von Rad, U., 1987. Lower Cretaceous pelagic sediments of Deep Sea Drilling Project Site 603, western North Atlantic: a synthesis. In van Hinte, J. E., Wise, S. W., Jr., et al., Init. Repts. DSDP, 93: Washington (U.S. Govt. Printing Office), 1305-1331.

Ogg, J. G., Hasenyager, R. W., Wimbledon, W. A., Channell, J.E.T., and Bralower, T. J., 1991. Magnetostratigraphy of the Jurassic-Cretaceous boundary interval-Tethyan and English faunal realms. Cretaceous Res., 12:455-482.

Ogg, J. G., Robertson, A.H.F., and Jansa, L. F., 1983. Jurassic sedimentation history of Site 534 (western North Atlantic) and of the Atlantic-Tethys seaway. In Sheridan, R. E., Gradstein, F. M., et al., Init. Repts. DSDP, 76: Washington (U.S. Govt. Printing Office), 829-884.

Ogg, J. G., Steiner, M. B., Oloriz, F., and Tavera, J. M., 1984. Jurassic magnetostratigraphy: 1. Kimmeridgian-Tithonian of Sierra Gorda and Carcabuey, southern Spain. Earth Planet. Sci. Lett., 71:147-162.

Oglesby, R., and Park, J., 1989. The effect of precessional insolation changes on Cretaceous climate and cyclic sedimentation. J. Geophys. Res., 94:14793-14816.

Olivarez, A. M., and Owen, R. M., 1989. Plate tectonic reorganizations: implications regarding the formation of hydrothermal ore deposits. Mar. Mining, 14:123-138.

Owen, R. M., and Rea, D. K., 1985. Sea-floor hydrothermal activity links climate to tectonics: the Eocene carbon dioxide greenhouse. Science, 227:166-169.

Palmer, A. R., 1983. The Decade of North American Geology time scale. Geology, 11:503-504.

Parker, R. L., 1988. Astatistical theory of seamount magnetization. J. Geophys. Res., 93:3105-3115.

, 1991. A theory of ideal bodies for seamount magnetization. $J$. Geophys. Res., 96:16101-16112.

Parsons, B., and Sclater, J. G., 1977. An analysis of the variation of ocean floor bathymetry and heat flow with age. J. Geophys. Res., 82:803-827.

Pringle, M. S., Staudigel, H., and Gee, J., 1991. Jasper Seamount: seven million years of volcanism. Geology, 19:364-368.

Rangin, C., Steinberg, M., and Bonnot-Courtois, C., 1981. Geochemistry of the Mesozoic bedded cherts of central Baja California (Vizcaino-CedrosSan Benito): implications for paleogeographic reconstructions of an old oceanic basin. Earth Planet. Sci. Lett., 54:313-322.

Rea, D. K., 1990. Aspects of atmospheric circulation: the late Pleistocene (0-950,000 yr) record of eolian deposition in the Pacific Ocean. Palaeogeogr., Palaeoclimatol., Palaeoecol., 73:11-23.

Rea, D. K., Leinen, M., and Janecek, T., 1985. A geological approach to the long-term history of atmospheric circulation. Science, 227:721-725.

Rea, D. K., Pisias, N. G., and Newberry, T., 1991. Late Pleistocene paleoclimatology of the central Equatorial Pacific: flux patterns of biogenic sediments. Paleoceanography, 6:227-244.

Rea, D. K., Zachos, J. C., Owen, R. M., and Gingerich, P. D., 1990. Global change at the Paleocene-Eocene boundary: climatic and evolutionary effects of tectonic events. Palaeogeogr., Palaeoclimatol., Palaeoecol, 79:117-128.

Riech, V., and von Rad, U., 1979. Silica diagenesis in the Atlantic Ocean: diagenetic potential and transformations. In Talwani, M., Hay, W., and Ryan, W.BF. (Eds.), Deep Drilling Results in the Atlantic Ocean: Continents, Margins, and Paleoenvironments. Am. Geophys. Union, Maurice Ewing Ser., 3:315-340.

Riedel, W. R., and Sanfilippo, A., 1974. Radiolaria from the southern Indian Ocean, DSDP Leg 26. In Davies, T. A., Luyendyk, B. P., et al., Init. Repts. DSDP, 26: Washington (U.S. Govt. Printing Office), 771-814. 
Robertson, A.H.F., 1978. Metallogenesis along a fossil oceanic fracture zone: Arakapas Fault Belt, Troodos Massif, Cyprus. Earth Planet. Sci. Lett., 41:317-329.

1981. Metallogenesis on a Mesozoic passive continental margin, Antalya Complex, southwest Turkey. Earth Planet. Sci. Lett., 54:323-345.

Robertson, A.H.F., and Bliefnick, D. M., 1983. Sedimentology and origin of Lower Cretaceous pelagic carbonates and redeposited clastics, Blake-Bahama Formation, Deep Sea Drilling Project Site 534, western Equatorial Atlantic. In Sheridan, R. E., Gradstein, F. M., et al., Init. Repts. DSDP, 76: Washington (U.S. Govt. Printing Office), 795-828.

Roth, P. H., 1973. Calcareous nannofossils-Leg 17, Deep Sea Drilling Project. In Winterer, E. L., Ewing, J. I., et al., Init. Repts. DSDP, 17: Washington (U.S. Govt. Printing Office), 695-795.

Ruiz-Ortiz, P. A., Bustillo, M. A., Molina, J. M., 1989. Radiolarite sequences of the Subbetic, Betic Cordillera, southern Spain. In Hein, J. R., and Obradovic, J. (Eds.), Siliceous Deposits of the Tethys and Pacific Region: New York (Springer-Verlag), 107-127.

Sager, W. W., 1987. Late Eocene and Maastrichtian paleomagnetic poles for the Pacific plate: implications for the validity of seamount paleomagnetic data. Tectonophysics, 144:301-314.

- in press. Seamount age estimates from paleomagnetism and their implications for the history of volcanism on the Pacific Plate. In Keating, B. H., and Bolton, B. (Eds.), Geology and Offshore Mineral Resources of the Central Pacific Basin. Circum-Pac. Counc. Energy Mineral Resour., Earth Sci. Ser., 20.

Sager, W. W., Handschumacher, D. W., Hilde, T.W.C., and Bracey, D. R., 1988. Tectonic evolution of the northern Pacific plate and Pacific-FarallonIzanagi triple junction in the Late Jurassic and Early Cretaceous (M21M10). Tectonophysics, 155:345-364.

Sager, W. W., and Pringle, M. S., 1988. Mid-Cretaceous to Early Tertiary apparent polar wander path of the Pacific Plate. J. Geophys. Res., 93:11753-11771.

Sayre, W. O., 1981. Preliminary report on the paleomagnetism of Aptian and Albian limestones and trachytes from the Mid-Pacific Mountains and Hess Rise, Deep Sea Drilling Project Leg 62. In Thiede, J., Vallier, T. L., et al., Init. Repts. DSDP, 62: Washington (U.S. Govt. Printing Office), 983-994.

Schlanger, S. O., and Jenkyns, H. C., 1976. Cretaceous oceanic anoxic events: causes and consequences. Geol. Mijnbouw, 55:179-184

Schlanger, S. O., Douglas, R. G., Lancelot, Y., Moore, T. C., Jr., and Roth, P. H., 1973. Fossil preservation and diagenesis of pelagic carbonates from the Magellan Rise, central North Pacific Ocean. In Winterer, E. L., Ewing, J. I., et al., Init. Repts. DSDP, 17: Washington (U.S. Govt. Printing Office),

Schlanger, S. O., Jenkyns, H. C., and Premoli-Silva, I., 1981. Volcanism and vertical tectonics in the Pacific Basin related to global Cretaceous transgressions. Earth Planet. Sci. Lett., 52:435-449.

Sedlock, R. L., and Isozaki, Y., 1990. Lithology and biostratigraphy of Franciscan-like chert and associated rocks in west-central Baja California, Mexico. Geol. Soc. Am. Bull., 102:852-864.

Sharman, G. F., and Risch, D. L., 1988. Northwest Pacific tectonic evolution in the Middle Mesozoic. Tectonophysics, 155:331-344.

Sheridan, R. E., 1983. Phenomena of pulsation tectonics related to the breakup of the eastern North American continental margin. In Sheridan, R. E., Gradstein, F. M., et al., Init. Repts. DSDP, 76: Washington (U.S. Govt. Printing Office), 897-909.

Shibuya, H., and Sasajima, S., 1986. Paleomagnetism of red cherts: a case study in the Inuyama area, central Japan. J. Geophys. Res., 91:14105-14116.

Shipboard Scientific Party, 1973a. Site 167. In Winterer, E. L., Ewing, J. I., et al., Init. Repts. DSDP, 17: Washington (U.S. Govt. Printing Office), 145-234.

1973b. Pliocene volcanogenic sediments and Mesozoic chalks southeast of Japan: DSDP Site 196. In Heezen, B. C., MacGregor, I. D., et al., Init. Repts. DSDP, 20: Washington (U.S. Govt. Printing Office), 33-44.

1975a. Site 303: Japanese magnetic lineations. In Larson, R. L., Moberly, R., et al., Init. Repts. DSDP, 32: Washington (U.S. Govt. Printing Office), 17-43

1975b. Site 304: Japanese magnetic lineations. In Larson, R. L., Moberly, R., et al., Init. Repts. DSDP, 32: Washington (U.S. Govt. Printing Office), 45-73.

, 1975c. Site 305: Shatsky Rise. In Larson, R. L., Moberly, R., et al., Init. Repts. DSDP, 32: Washington (U.S. Govt. Printing Office), 75-158. 1975d. Site 306: Shatsky Rise. In Larson, R. L., Moberly, R., et al., Init. Repts. DSDP, 32: Washington (U.S. Govt. Printing Office), 159-191. 1975e. Site 307: Hawaiian magnetic lineations. In Larson, R. L., Moberly, R., et al., Init. Repts. DSDP, 32: Washington (U.S. Govt. Printing Office), 193-214.

1976. Site 319. In Yeats, R. S., Hart, S. R., et al., Init. Repts. DSDP, 34: Washington (U.S. Govt. Printing Office), 19-80.

, 1981a. Site 463: western Mid-Pacific Mountains. In Thiede, J., Vallier, T. L., et al., Init. Repts. DSDP, 62: Washington (U.S. Govt. Printing Office), 33-156.

1981b. Site 464: northern Hess Rise. In Thiede, J., Vallier, T. L., et al., Init. Repts. DSDP, 62: Washington (U.S. Govt. Printing Office), 157-197.

1982. Site 460: inner wall of the Mariana Trench. In Hussong. D. M., Uyeda, S., et al., Init. Repts. DSDP, 60: Washington (U.S. Govt. Printing Office), 371-397.

1983. Site 534: Blake-Bahama Basin. In Sheridan, R. E., Gradstein, F. M., et al., Init. Repts. DSDP, 76: Washington (U.S. Govt. Printing Office), 141-340.

1985. Site 462. In Moberly, R., Schlanger, S. O., et al., Init. Repts. DSDP. 89: Washington (U.S. Govt. Printing Office).

1987. Site 596: hydraulic piston coring in an area of low surface productivity in the southwest Pacific. In Menard, H. W., Natland, J. H. Jordan, T. H., Orcutt, J. A., et al., Init. Repts. DSDP, 91: Washington (U.S. Govt. Printing Office), 245-270.

1990a. Explanatory notes. In Lancelot, Y., Larson, R. L., et al., Proc. ODP, Init. Repts., 129: College Station, TX (Ocean Drilling Program), 5-29.

1990b. Site 800. In Lancelot, Y., Larson, R. L., Proc. ODP, Init.

Repts., 129: College Station, TX (Ocean Drilling Program), 33-89.

1990c. Site 801. In Lancelot, Y., Larson, R. L., Proc. ODP, Init.

Repts., 129: College Station, TX (Ocean Drilling Program), 91-170.

, 1990d. Site 802. In Lancelot, Y., Larson, R. L., Proc. ODP, Init. Repts., 129: College Station, TX (Ocean Drilling Program), 171-243..

Sliter, W. V., 1989. Aptian anoxia in the Pacific Basin. Geology, 17:909-912.

Steiner, M. B., 1981a. Paleomagnetism of the Cretaceous section, Site 462. In Larson, R. L., Schlanger, S. O., et al., Init. Repts. DSDP, 61: Washington (U.S. Govt. Printing Office), 711-716.

1981b. Paleomagnetism of the igneous complex, Site 462. In Larson, R. L., Schlanger, S. O., et al., Init. Repts. DSDP, 61: Washington (U.S. Govt. Printing Office), 717-729.

Sundvik, M. T., and Larson, R. L., 1988. Seafloor spreading history of the western North Atlantic Basin derived from the Keathley sequence and computer graphics. Tectonophysics, 155:49-71.

Takahashi, K., 1987. Radiolarian flux and seasonality: climatic and El Niño response in the subarctic Pacific, 1982-1984. Global Biogeochem. Cycles, 1:213-231.

Takahashi, K., and Honjo, S., 1983. Radiolarian skeletons: size, weight, sinking speed, and residence time in tropical pelagic oceans. Deep Sea Res. Part A, 30:543-568.

Tamaki, K., Joshima, M., and Larson, R. L., 1979. Remnant Early Cretaceous spreading center in the central Pacific Basin. J. Geophys. Res., 84:4501-4510.

Tamaki, K., and Larson, R. L., 1988. The Mesozoic tectonic history of the Magellan microplate in the western central Pacific. J. Geophys. Res., 93:2857-2874.

Tarduno, J. A., Sliter, W. V., Bralower, T. J., McWilliams, M., Premoli-Silva, I., and Ogg, J. G., 1989. M-sequence reversals recorded in DSDP sediment cores from the western Mid-Pacific Mountains and Magellan Rise. Geol. Soc. Am. Bull., 101:1306-1316.

Tarduno, J. A., Sliter, W. V., Kroenke, L., Leckie, M., Mayer, H., Mahoney, J. J., Musgrave, R., Storey, M., and Winterer, E. L., 1991. Rapid formation of Ontong Java Plateau by Aptian mantle plume volcanism. Science, 254:399-403.

Theyer, F., Vincent, E., and Mayer, L. A., 1989. Sedimentation and paleoceanography of the central equatorial Pacific. In Winterer, E. L., Hussong, D. M., and Decker, R. W. (Eds.), The Geology of North America (Vol. N): The Eastern Pacific Ocean and Hawaii. Geol. Soc. Am., 347-372.

Thiede, J., Dean, W. E., and Claypool, G. E., 1982. Oxygen deficient depositional environments in the mid-Cretaceous tropical and subtropical Pacific Ocean. In Schlanger, S. O., and Cita, M. B. (Eds.), Nature and Origin of Cretaceous Carbon-rich Facies: London (Academic Press), 79-100.

Timofeev, P. P., and Bogolyubova, L. I., 1981. Cretaceous sapropelic deposits of Deep Sea Drilling Project Sites 463, 465, and 466. In Thiede, 
J., Vallier, T. L., et al., Init. Repts. DSDP, 62: Washington (U.S. Govt. Printing Office), 891-901.

Tucholke, B. E., and Vogt, P. R., 1979. Western North Atlantic: sedimentation evolution and aspects of tectonic history. In Tucholke, B. E., Vogt, P. R., et al., Init. Repts. DSDP, 43: Washington (U.S. Govt. Printing Office), 791-825.

van Andel, T. H., Heath, G. R., and Moore, T. C., 1975. Cenozoic Tectonics, Sedimentation, and Paleoceanography of the Central Equatorial Pacific. Mem.-Geol. Soc. Am., 143.

Vogt, P. R., 1989. Volcanogenic upwelling of anoxic, nutrient-rich water: A possible factor in carbonate-bank/reef demise and benthic faunal extinctions? Geol. Soc. Am. Bull., 101:1225-1245.

Vogt, P. R., Nishimura, C., and Jarvis, J., 1990. Prospecting for active volcanism. Eos, 71:773-780.

Weaver, C. E., 1989. Clays, Muds, and Shales: New York (Elsevier).

White, R. S., Detrick, R. S., Mutter, J. C., Buhl, P., Minshull, T. A., and Morris, E., 1990. New seismic images of oceanic crustal structure. Geology, 18:462-465,
Winterer, E. L., 1991. The Tethyan Pacific during Late Jurassic and Cretaceous times. Palaeogeogr., Palaeoclimatol., Palaeoecol., 87:253-265.

Winterer, E. L., Ewing, J. I., et al., 1973. Init. Repts. DSDP, 17: Washington (U.S. Govt. Printing Office).

Winterer, E. L., and Metzler, C. V., 1984. Origin and subsidence of guyots in Mid-Pacific Mountains. J. Geophys. Res., 89:9969-9979.

Winterer, E. L., Metzler, C. V., and Sarti, M., 1991. Neptunian dykes and associated breccias (Southern Alps, Italy and Switzerland): role of gravity sliding in open and closed systems. Sedimentology, 38:381-404.

Yamamoto, S., 1988. Ferromagnesian and metalliferous pelagic clay minerals in oceanic sediments. In Chilingarian, G. V., and Wolf, K. H. (Eds), Diagenesis II: New York (Elsevier), Dev. in Sedimentol. Ser., 43:115-146.

Date of initial receipt: 13 June 1991

Date of acceptance: 31 March 1992

Ms 129B-117 